\title{
WestVirginiaUniversity
}

THE RESEARCH REPOSITORY @ WVU

Graduate Theses, Dissertations, and Problem Reports

2014

\section{Performance of Reformed Low-Sulfur Liquid Fuels in a Solid Oxide Fuel Cell}

\author{
Tristan Jordan McQuain
}

Follow this and additional works at: https://researchrepository.wvu.edu/etd

\section{Recommended Citation}

McQuain, Tristan Jordan, "Performance of Reformed Low-Sulfur Liquid Fuels in a Solid Oxide Fuel Cell" (2014). Graduate Theses, Dissertations, and Problem Reports. 6206.

https://researchrepository.wvu.edu/etd/6206

This Thesis is protected by copyright and/or related rights. It has been brought to you by the The Research Repository @ WVU with permission from the rights-holder(s). You are free to use this Thesis in any way that is permitted by the copyright and related rights legislation that applies to your use. For other uses you must obtain permission from the rights-holder(s) directly, unless additional rights are indicated by a Creative Commons license in the record and/ or on the work itself. This Thesis has been accepted for inclusion in WVU Graduate Theses, Dissertations, and Problem Reports collection by an authorized administrator of The Research Repository @ WVU. For more information, please contact researchrepository@mail.wvu.edu. 


\title{
Performance of Reformed Low-Sulfur Liquid \\ Fuels in a Solid Oxide Fuel Cell
}

\section{Tristan Jordan McQuain}

\author{
Thesis submitted \\ to the Benjamin M. Statler College of Engineering and Mineral Resources \\ at West Virginia University \\ in partial fulfillment of the requirements for the degree of \\ Master of Science in \\ Chemical Engineering
}

John W. Zondlo, Ph.D., Chair

Charter Stinespring, Ph.D.

Edward Sabolsky, Ph.D.

Dushyant Shekhawat, Ph.D.

Department of Chemical Engineering

Morgantown, West Virginia

2014

Keywords: Solid Oxide Fuel Cell, Reformer

Copyright 2014 Tristan Jordan McQuain 


\begin{abstract}
Performance of Reformed Low-Sulfur Liquid Fuels in a Solid Oxide Fuel Cell
\end{abstract}

\title{
Tristan Jordan McQuain
}

A solid oxide fuel cell (SOFC) is a device capable of converting chemical energy from gaseous fuels into useable electrical energy at high efficiencies. Since the United States transportation sector infrastructure is currently based on liquid fuels, this opens up a large market for alternative power units utilizing SOFC technology for liquid fuels. In this work, a novel rhodium and strontium-substituted lanthanum zirconate pyrochlore (LSRZ) catalyst developed by the U.S. Department of Energy's National Energy Technology Laboratory (NETL) was utilized in a reforming reactor to convert low-sulfur liquid hydrocarbon fuels to syngas for direct use in a SOFC. The SOFC was performance tested on the reformate from the reactor. A main aspect of this work was the design, construction, integration, and testing of a continuous flow system consisting of a fuel vaporization system, fuel reforming reactor, and a high-temperature SOFC. The liquid fuels tested include $n$-tetradecane, a fatty-acid methyl ester (FAME) mixture, two different ultra-low-sulfur diesel (ULSD) fuels, and a desulfurized version of the military logistic fuel JP-8. It was found that the reformer/SOFC system could be operated on the low-sulfur liquid fuels using the new LSRZ catalyst developed by the NETL. The sulfur-free compound $n$ tetradecane was successfully reformed multiple times for periods of up to 50 hours with no pressure increases in the reactor or deterioration of fuel cell performance. The sulfur-free FAME mixture was successfully reformed and continuously operated in the SOFC for 100 hours. The desulfurized JP-8 containing 11.7 ppm of thiophenic sulfur was successfully reformed and utilized continuously in the SOFC for a total time of 93 hours. Both diesel fuels caused pressure increases in the reforming reactor and this required system shut down within 30 hours of operation. It was found that the application of a thin layer of the LSRZ catalyst on top of the SOFC anode using a Ni-based paste reduced carbon formation on the anode caused by gaseous hydrocarbons left over from the reforming process. This new application for the LSRZ catalyst promoted in-situ reforming on the SOFC anode, allowing the cell to operate more consistently throughout the experiments. 


\section{Dedication}

I would like to dedicate this work to my loving family and friends who have helped me in my pursuit of higher education. I would like to dedicate this work to my mother and father, Bruce McQuain and Janine Bart. I would especially like to dedicate this work to my grandfather Albert C. McQuain, Sr., who was my inspiration throughout this endeavor, and my late grandmother Glenda Rae McQuain, who passed during the completion of this effort. I would also like to dedicate this work to Amanda Shreve, who was encouraging throughout my attempt. 


\section{Acknowledgements}

First and foremost, I would like to thank my research advisor, Dr. John Zondlo for his unwavering support throughout this research. Dr. Zondlo provided not only guidance in the laboratory, but also in the classroom. It was with his invaluable leadership that the design, construction, and operation of the reforming reactor and fuel cell were possible. Without him, the completion of this work would not have been possible. Special thanks goes to Dr. Chunchuan Xu for his superb laboratory skills during the construction and operation of the fuel cell. He was always available to lend a hand and watch over the cell. Additional thanks goes to Mr. Jim Hall for his help in the custom machining required for the construction of the reforming reactor and fuel cell. He was instrumental in the creation of a system that actually worked. I would like to thank Dr. Michael Timko from Aerodyne Research, Inc. for providing the desulfurized JP-8 samples. I would also like to acknowledge the kind folks at the NETL: Mr. Mark Smith, Mr. Daniel Haynes, Mr. Dave Berry, Mr. Tom Simonyi, and especially Dr. Dushyant Shekhawat and Mr. Donald Floyd. These men were generous enough to lend their precious time to aid in this work. They not only provided their guidance, but also their valuable reforming catalyst, equipment, and samples essential to the operation of the reforming reactor. Dr. Shekhawat was a key contributor to this work and I thank him with much appreciation. 


\section{Contents}

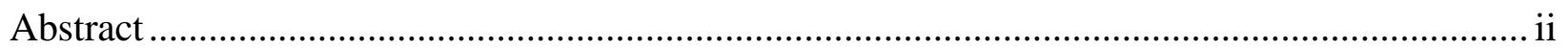

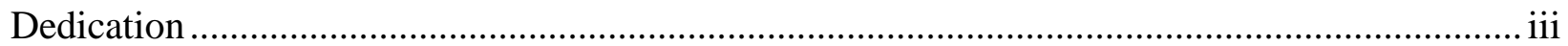

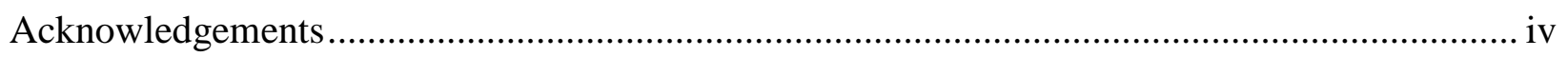

Figures..................................................................................................................... vii

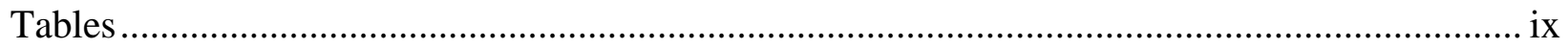

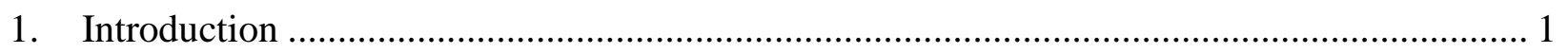

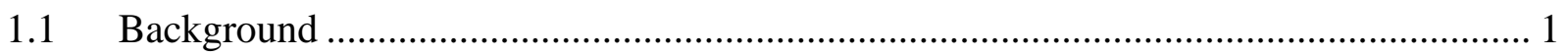

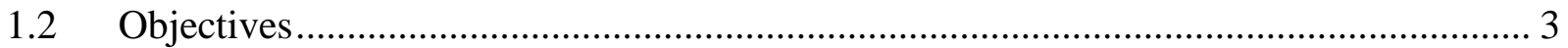

1.3 Technical Approach ............................................................................................ 4

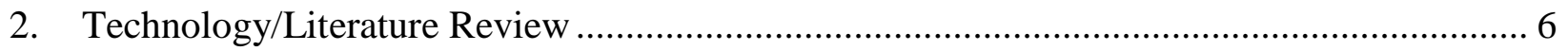

2.1. Current Practice in Solid Oxide Fuel Cell Technology ..................................................... 6

2.1.1. Cell Evaluation Methods.................................................................................... 10

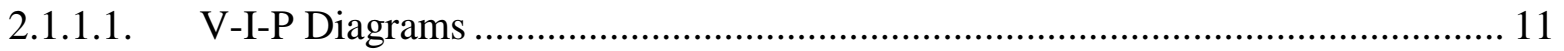

2.1.1.2. Electrochemical Impedance Spectroscopy.......................................................... 15

2.2 Overview of Reforming ........................................................................................ 18

2.3. Catalysts Utilized for Fuel Reforming ........................................................................ 19

2.3.1 NETL Reforming Catalyst Development ............................................................... 20

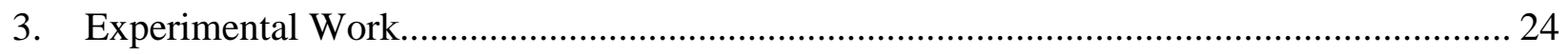

3.1. Experimental Setup ................................................................................................. 24

3.1.1. Fuel Vaporization System and Humidifier ............................................................... 25

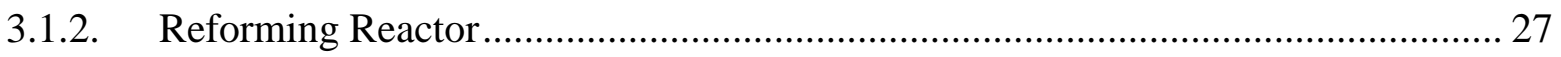

3.1.3. Solid Oxide Fuel Cell Structure and Composition .................................................... 28

3.1.4. Solid Oxide Fuel Cell Testing System..................................................................... 29

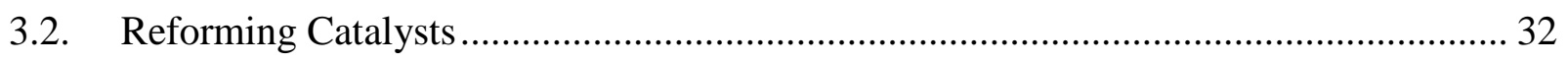

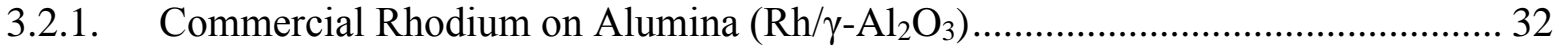

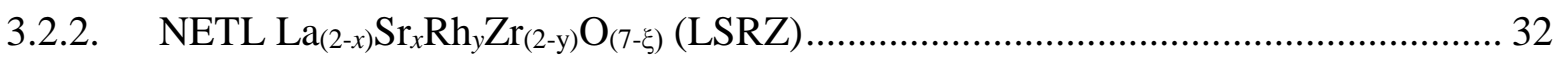

3.3. Low-Sulfur Liquid Fuels ............................................................................................ 33

3.3.1. n-tetradecane (TD) ............................................................................................... 33

3.3.2. Fatty Acid Methyl Ester (FAME) Mixture ………………….................................. 34 


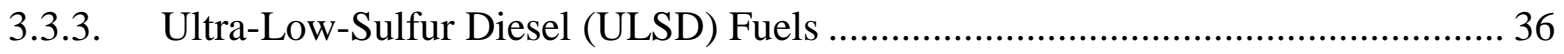

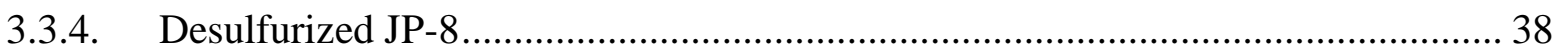

3.3.5. Additional Fuel Information and Component Summary ................................... 39

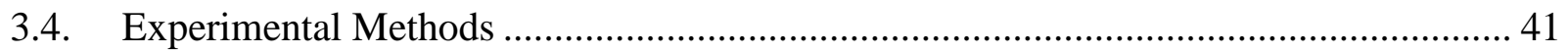

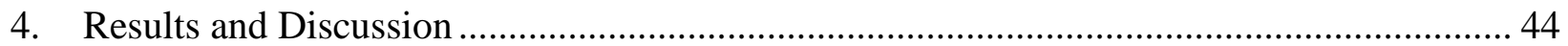

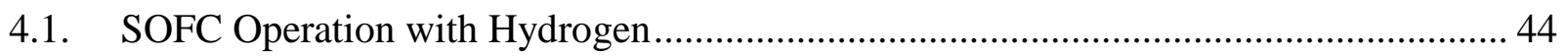

4.2. Reforming Experiments and Parameters.................................................................. 46

4.3. Initial Trial Operation of SOFC on Reformed Desulfurized JP-8 ............................ 49

4.4. SOFC Operation on Reformed $n$-tetradecane ....................................................... 53

4.5. SOFC Operation on Reformed Desulfurized JP-8 .................................................. 59

4.6. SOFC Operation on Reformed Ultra-Low-Sulfur Diesel Fuel 1 (ULSD 1) ................. 66

4.7. SOFC Operation on Reformed FAME Mixture .................................................... 70

4.8. SOFC Operation on Reformed Ultra-Low-Sulfur Diesel Fuel 2 (ULSD 2) ................ 75

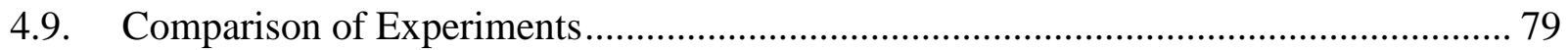

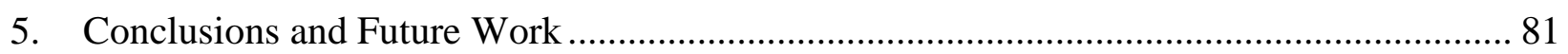

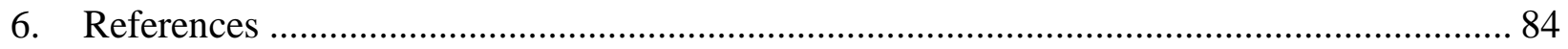




\section{Figures}

Figure 2.1. Diagram of $\mathrm{O}^{=}$transfer through the electrolyte during $\mathrm{H}_{2} \mathrm{O}$ formation from $\mathrm{H}_{2}$ on a SOFC.

Figure 2.2. Diagram of $\mathrm{O}^{=}$transfer through the electrolyte during $\mathrm{CO}_{2}$ formation from $\mathrm{CO}$ on a SOFC.

Figure 2.3. Graph showing the V-I curve for a typical SOFC operating at about $800^{\circ} \mathrm{C} \ldots \ldots \ldots . . . . .11$

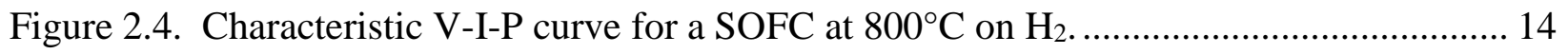

Figure 2.5. Characteristic Nyquist plot for a SOFC .......................................................... 16

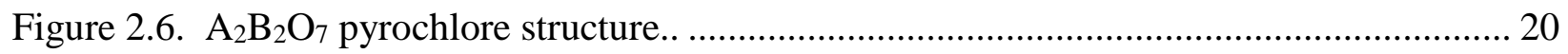

Figure 3.1. Block flow diagram of reformer/fuel cell system.............................................. 25

Figure 3.2. Diagram of fuel vaporization system, humidifier, and reactor............................... 27

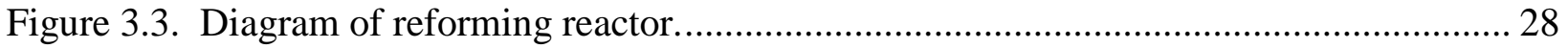

Figure 3.4. Button cell contact configuration on the anode of the MSRI SOFC...................... 29

Figure 3.5. Diagram of the solid oxide fuel cell system.................................................... 31

Figure 4.1. SOFC voltage and current at $800{ }^{\circ} \mathrm{C}$ for $100 \mathrm{sccm}$ pure hydrogen......................... 44

Figure 4.2. V-I-P diagram for $100 \mathrm{sccm}$ pure hydrogen at 65 hours in SOFC at $800{ }^{\circ} \mathrm{C} \ldots \ldots \ldots . . . .45$

Figure 4.3. V-I-P diagram for $200 \mathrm{sccm}$ pure $\mathrm{H}_{2}$ and $0.110 \mathrm{~mL} / \mathrm{min} \mathrm{JP}-8$ in SOFC at $800{ }^{\circ} \mathrm{C} . . .49$

Figure 4.4. Cell impedance spectra comparing 200 sccm $\mathrm{H}_{2}$ in black opened dots and 0.110 $\mathrm{ml} / \mathrm{min}$ JP-8 fuel in blue solid dots under a DC bias of $800 \mathrm{mV}$.......................... 50

Figure 4.5. SOFC voltage at $800^{\circ} \mathrm{C}$ for $0.110 \mathrm{~mL} / \mathrm{min}$ reformed $\mathrm{JP}-8$ using $\mathrm{Rh} / \gamma-\mathrm{Al}_{2} \mathrm{O}_{3}$ catalyst. 51

Figure 4.6. SOFC voltage at $800^{\circ} \mathrm{C}$ as a function of time for different JP-8 flowrates.............. 52

Figure 4.7. SOFC anode after 3 hour JP-8 run on commercial $0.5 \mathrm{wt} \% \mathrm{Rh} / \gamma-\mathrm{Al}_{2} \mathrm{O}_{3}$ catalyst.... 53

Figure 4.8. SOFC voltage at $800^{\circ} \mathrm{C}$ under a current load of $0.50 \mathrm{~A} \mathrm{~cm}^{-2}$ for $0.136 \mathrm{~mL} / \mathrm{min}$ reformed $n$-tetradecane using $\mathrm{Rh} / \gamma-\mathrm{Al}_{2} \mathrm{O}_{3}$ catalyst in the reformer. ....................... 55

Figure 4.9. Comparison of SOFC performance at $800^{\circ} \mathrm{C}$ with $200 \mathrm{sccm}$ pure hydrogen and reformed $n$-tetradecane using commercial $\mathrm{Rh} / \gamma-\mathrm{Al}_{2} \mathrm{O}_{3}$ catalyst in the reformer....... 56 
Figure 4.10. SOFC voltage at $800^{\circ} \mathrm{C}$ under a current load of $0.50 \mathrm{~A} \mathrm{~cm}^{-2}$ for $200 \mathrm{sccm}$ hydrogen and $0.136 \mathrm{~mL} / \mathrm{min}$ reformed $n$-tetradecane using LSRZ catalyst in the reformer and on the SOFC anode. 57

Figure 4.11. Comparison of SOFC performance at $800^{\circ} \mathrm{C}$ with $200 \mathrm{sccm}$ pure hydrogen and reformed $n$-tetradecane using NETL LSRZ catalyst in the reformer and on the SOFC anode. 58

Figure 4.12. SOFC voltage at $800^{\circ} \mathrm{C}$ under a current load of $0.50 \mathrm{~A} \mathrm{~cm}^{-2}$ for $0.094 \mathrm{~mL} / \mathrm{min}$ reformed desulfurized JP-8 using LSRZ catalyst in the reformer and on the SOFC anode. 60

Figure 4.13. Cell impedance spectra under a DC bias of $0.703 \mathrm{~V}$ for $100 \mathrm{sccm}$ pure hydrogen in red open dots and $0.094 \mathrm{~mL} / \mathrm{min} \mathrm{JP}-8$ fuel at 2-hr and 140-hr in blue and green closed dots, respectively.

Figure 4.14. Comparison of SOFC performance at $800^{\circ} \mathrm{C}$ with $100 \mathrm{sccm}$ pure hydrogen and reformed desulfurized JP-8 using NETL LSRZ catalyst in the reformer and on the SOFC anode.

Figure 4.15. SOFC voltage at $800^{\circ} \mathrm{C}$ under a current load of $0.50 \mathrm{~A} \mathrm{~cm}^{-2}$ for $0.096 \mathrm{~mL} / \mathrm{min}$ reformed $n$-tetradecane and $0.084 \mathrm{~mL} / \mathrm{min}$ ULSD 1 using LSRZ catalyst in the reformer and on the SOFC anode.

Figure 4.16. Comparison of SOFC performance at $800^{\circ} \mathrm{C}$ with pure hydrogen and reformed ULSD 1 at 25 hours and 49 hours using NETL LSRZ catalyst in the reformer and on the SOFC anode. 69

Figure 4.17. Reformer pressure and SOFC voltage at $800^{\circ} \mathrm{C}$ under a current load of $0.50 \mathrm{~A} \mathrm{~cm}^{-2}$ for $0.116 \mathrm{~mL} / \mathrm{min}$ reformed FAME mixture using LSRZ catalyst in the reformer and on the SOFC anode 70

Figure 4.18. Comparison of SOFC performance at $800^{\circ} \mathrm{C}$ with pure hydrogen and reformed FAME mixture at one hour using NETL LSRZ catalyst in the reformer and on the SOFC anode. 72

Figure 4.19. Reformer pressure and SOFC voltage at $800^{\circ} \mathrm{C}$ under a current load of $0.50 \mathrm{~A} \mathrm{~cm}^{-2}$ for $0.099 \mathrm{~mL} / \mathrm{min}$ reformed ULSD 2 using the LSRZ catalyst in the reformer and on the SOFC anode. 75

Figure 4.20. Picture of the SOFC anode after 50-hour operation on reformed ULSD 2........... 77

Figure 4.21. Reformer pressure and SOFC voltage at $800^{\circ} \mathrm{C}$ under a current load of $0.50 \mathrm{~A} \mathrm{~cm}^{-2}$ for $0.099 \mathrm{~mL} / \mathrm{min}$ reformed ULSD 2 using LSRZ catalyst in the reformer and on the SOFC anode. 78 


\section{Tables}

Table 2.1. Product yields and carbon deposited for $\mathrm{Rh} / \gamma-\mathrm{Al}_{2} \mathrm{O}_{3}$ and pyrochlores after 5 hour reforming of $\mathrm{TD}$ at $\mathrm{O} / \mathrm{C}_{\mathrm{A}}=1.2,900^{\circ} \mathrm{C}, 0.23 \mathrm{MPa}$, and $50,000 \mathrm{scc}_{\text {catalyst }}{ }^{-1} \mathrm{hr}^{-1} \ldots \ldots . .22$

Table 2.2. Amount of carbon formed on $0.5 \mathrm{wt} \% \mathrm{Rh} / \gamma-\mathrm{Al}_{2} \mathrm{O}_{3}$ and pyrochlore catalysts (LZ, $\mathrm{LRZ}$, and LSRZ) at end of $5 \mathrm{hr}$ sulfur experiment at $\mathrm{O} / \mathrm{C}=1.2,50,000 \mathrm{scc}$ gcatalyst $^{-1}$ $\mathrm{hr}^{-1}, 0.23 \mathrm{MPa}$ and $900^{\circ} \mathrm{C}$..

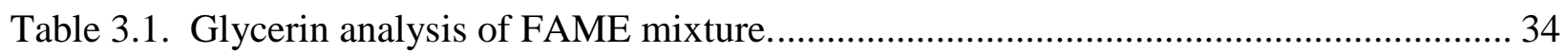

Table 3.2. Methyl ester analysis of FAME mixture..................................................................... 35

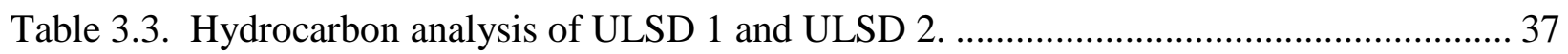

Table 3.4. Hydrocarbon analysis of desulfurized JP-8 sample......................................................... 39

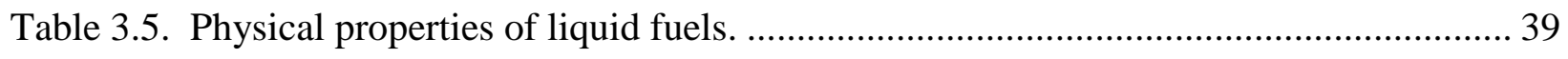

Table 3.6. Comparison of hydrocarbon content for selected fuels. ............................................... 40

Table 4.1. Reforming experiments and parameters..................................................................... 47

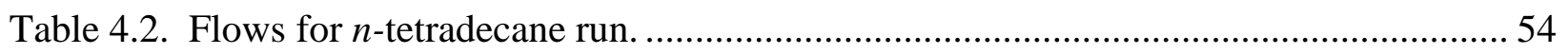

Table 4.3. Gas chromatograph analysis of reformed desulfurized JP-8. ....................................... 65

Table 4.4. Gas chromatograph analysis of reformed FAME mixture......................................... 73 


\section{Introduction}

\subsection{Background}

With the steadily increasing consumption of energy by the industrial, commercial, residential, and transportation sectors [1], there is an ever increasing need for economical and environmentally-friendly energy sources. In 2011, fossil fuels accounted for over $77 \%$ of U.S. total energy production, with coal and natural gas at $28.4 \%$ and $30.1 \%$ of total energy production, respectively [1]. Several billion dollars have been assigned over the last decade to clean coal research and development [2]. Concentration in developing new devices to utilize this clean coal and also natural gas has been an ongoing process. One such device that shows much promise is the high-temperature solid oxide fuel cell (SOFC). The use of SOFCs for the production of electricity has gained considerable interest in the past few decades.

A high-temperature SOFC is capable of converting chemical energy from gaseous fuels into useable electrical energy at high efficiencies [3-5]. Several advantages of the SOFC include a demonstrated efficiency approaching 60\% (HHV basis), superior environmental performance when compared to coal-fired power plants, quiet operation, co-generation of heat and power, transportation applications, and fuel flexibility [4-5]. Acceptable fuels can include low or high purity hydrogen, liquefied natural gas, pipeline natural gas, coal derived synthesis gas (syngas), biogases, methane, propane, and reformed liquids such as kerosene, gasoline, diesel, fuel oil, biodiesel, and jet fuel [5-14].

Also, there has been interest in replacing non-rechargeable batteries with systems that can produce power as needed. Batteries are heavy, can degrade rapidly, and are environmentally 
unfriendly. Fuels cells are being explored due to their portability, mobility, and relatively low weight. When compared to internal combustion engines, fuel cells operate more quietly, are more efficient, have cleaner emissions, and have very few, if any moving parts [15]. Although there are currently vehicles that operate on compressed gases, the majority of the infrastructure of the transportation sector in the United States is currently based on liquid fuels. Consequently, there has been considerable interest in generating hydrogen on an as-needed basis from liquid fuels. This will help to improve the heavy equipment requirements and safety issues related with the storage and usage of compressed gases. The use of liquid fuels as a chemical feedstock to reforming reactors has led to research into portable alternative power units (APUs) due to their high energy density [9-12, 14, 16-17]. Reforming anodes have also been investigated so that insitu reforming of a gaseous hydrocarbon or vaporized liquid fuel occurs on the anode of the fuel cell itself [8, 19-22].

One of the main areas of focus of this research will involve the reforming of liquid fuels via a reforming reactor. Reforming reactors can be used to convert a liquid hydrocarbon to a combination of gases which consist mostly of hydrogen and carbon monoxide. The reformed gases can then be sent to a fuel cell to produce electricity. This is not achieved without difficulty, as most liquid fuels contain sulfur compounds, which can negatively affect reforming catalysts [23-25]. Even if the reforming catalyst is sulfur-tolerant, gaseous hydrogen sulfide $\left(\mathrm{H}_{2} \mathrm{~S}\right)$ from the liquid fuel reforming process can react with the anode of the fuel cell in a reformer-fuel cell system, degrading the fuel cell’s performance [26-30]. Hydrogen sulfide has been observed to cause both reversible and irreversible damage to the standard Ni/YSZ cermet anode in SOFCs [31-35]. This work will focus on the reforming of low-sulfur liquid fuels to be directly used in a high-temperature SOFC. 


\subsection{Objectives}

This research was concerned with the reforming of liquid fuels for the production of hydrogen and carbon monoxide for use in a solid-oxide fuel cell system for the generation of usable electricity. This work primarily consisted of the performance testing of various reformed low-sulfur liquid fuels which were converted to electricity via a solid oxide fuel cell. The design, construction, integration, and testing of the fuel vaporization system, fuel reforming reactor system, and the solid oxide fuel cell system were all done in-house. All fuel cell testing was conducted on commercially available anode-supported Ni/YSZ button cells. The reforming catalysts were provided by the United States Department of Energy's National Energy Technology Laboratory in Morgantown, West Virginia. The long range goal of these efforts was to operate the reformer/SOFC system continuously for 100 hours on a variety of low-sulfur liquid fuels. Sulfur-free and sulfur-containing liquid fuels were tested to establish the performance of the fuel cell and reforming reactor. The fuel cell performance was characterized in-situ by monitoring the cell voltage at a constant current load verses time, the electrochemical impedance of the cell, and power density of the cell. 


\subsection{Technical Approach}

This project began with the design and fabrication of the reforming reactor system and the solid oxide fuel cell testing system. The reforming reactor was similar to the design utilized by the NETL for their catalyst studies and can be found in the literature [24]. As part of the reforming system, an integral liquid fuel vaporization system was also designed and constructed. They are both described in detail in Chapter 3. The SOFC testing system was based upon a proprietary NETL design and its basic components are described in Chapter 3. The design, fabrication, and integration of these two systems required custom plumbing, machining, and electrical work and therefore expended a relatively large amount of time compared to the entire span of this project.

The design and construction of the solid oxide fuel cell testing system was the first project to commence. After being fully constructed, the SOFC testing system had to undergo preliminary testing, known as the "shake-down” period, for de-bugging and leak detection. Using a commercially available fuel cell (to be described in Chapter 3), the initial testing of the SOFC system was done using dry hydrogen as the anode fuel gas. Once the system passed the preliminary testing, fuel cell characterization data were collected for a base-line comparison with later tests.

The design and construction of the reforming reactor and the liquid fuel vaporization system started after the SOFC system had undergone preliminary testing and characterization. This system also had to undergo preliminary testing for de-bugging and leak detection. The initial testing of the reforming system was performed using $n$-tetradecane as the liquid fuel, as it is an acceptable sulfur-free surrogate for diesel fuel [36]. 
Once the reforming system was operationally stable, the reactor outlet was introduced into the anode inlet of the fuel cell testing system. The initial test of the entire reforming/SOFC system was performed with $n$-tetradecane as the liquid fuel. The fuel cell characterization data collected were used as a base-line comparison for later tests of other liquid fuels.

The performance testing of the low-sulfur liquid fuels included a fatty acid methyl ester (FAME) mixture, two different ultra-low-sulfur diesel (ULSD) fuels, and the military jet fuel JP8. Fuel cell characterization data were collected for each individual run and compared to the data from the base-line characterizations from $n$-tetradecane and dry hydrogen. 


\section{Technology/Literature Review}

This chapter summarizes key technological aspects and also reviews past and recent works that have been published in journals and books on solid oxide fuel cell research and fuel reforming. The first section will give a summary of SOFC fundamentals, including: operation principles, cell characteristics, and cell evaluation methods. The next section will discuss the principles of fuel reforming, associated reactions, and catalysts involved.

\subsection{Current Practice in Solid Oxide Fuel Cell Technology}

A solid oxide fuel cell (SOFC) is a solid-state device that operates at high temperatures (typically $800^{\circ} \mathrm{C}-1100^{\circ} \mathrm{C}$ ) and utilizes a ceramic oxide ion-conducting electrolyte. Only two phases are required for this type of fuel cell, gas and solid. Both hydrogen and carbon monoxide can act as fuels in an SOFC. The SOFC consists of an anode, electrolyte, and cathode. Chemical reactions occur at the surface of the anode and cathode [37]. The net overall reactions that occur in the SOFC when using hydrogen and carbon monoxide as fuels are shown in Equations 2.1 and 2.2, respectively:

$$
\begin{aligned}
& 2 \mathrm{H}_{2}+\mathrm{O}_{2} \rightarrow 2 \mathrm{H}_{2} \mathrm{O} \\
& 2 \mathrm{CO}+\mathrm{O}_{2} \rightarrow 2 \mathrm{CO}_{2}
\end{aligned}
$$

Oxygen is the only gas species consumed at the cathode of a solid oxide fuel cell and combines with electrons to yield doubly ionized oxygen, as shown in Equation 2.3:

$$
O_{2}+4 e^{-} \rightarrow 2 O^{=}
$$


Hydrogen and carbon monoxide gases are reduced by doubly ionized oxygen via the catalyst at the anode to produce water, carbon dioxide, and electrons; these half-cell reactions are shown in Equations 2.4 and 2.5, respectively:

$$
\begin{aligned}
& \mathrm{H}_{2}+\mathrm{O}^{=} \rightarrow \mathrm{H}_{2} \mathrm{O}+2 e^{-} \\
& 2 \mathrm{CO}+2 \mathrm{O}^{=} \rightarrow 2 \mathrm{CO}_{2}+4 e^{-}
\end{aligned}
$$

The electrolyte has been engineered to selectively allow the passage of only certain ions and not electrons. The electrons produced at the anode travel through the external load to the cathode. This process utilizes the electrical energy at the load. Doubly ionized oxygen $\left(\mathrm{O}^{=}\right)$is the mobile ionic species which transports from the cathode through the electrolyte to the anode. The process by which a SOFC operates on hydrogen and carbon monoxide is illustrated in Figures 2.1 and 2.2, respectively.

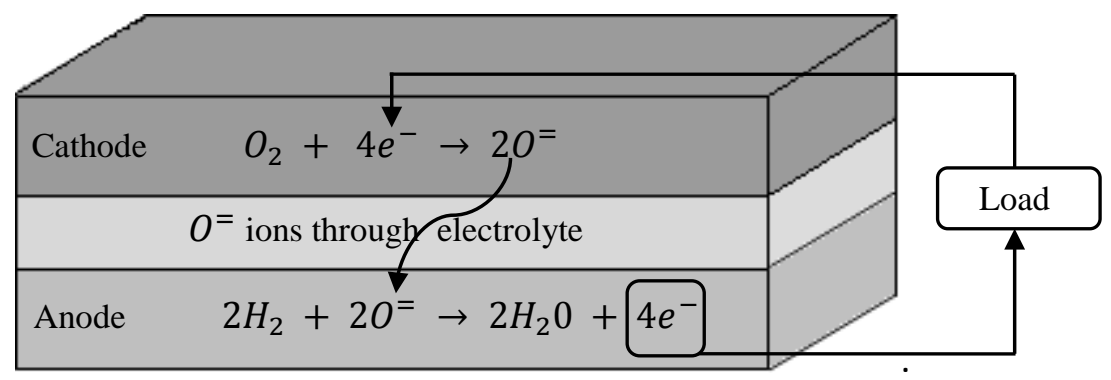

Figure 2.1. Diagram of $\mathrm{O}^{=}$transfer through the electrolyte during $\mathrm{H}_{2} \mathrm{O}$ formation from $\mathrm{H}_{2}$ on a SOFC. 


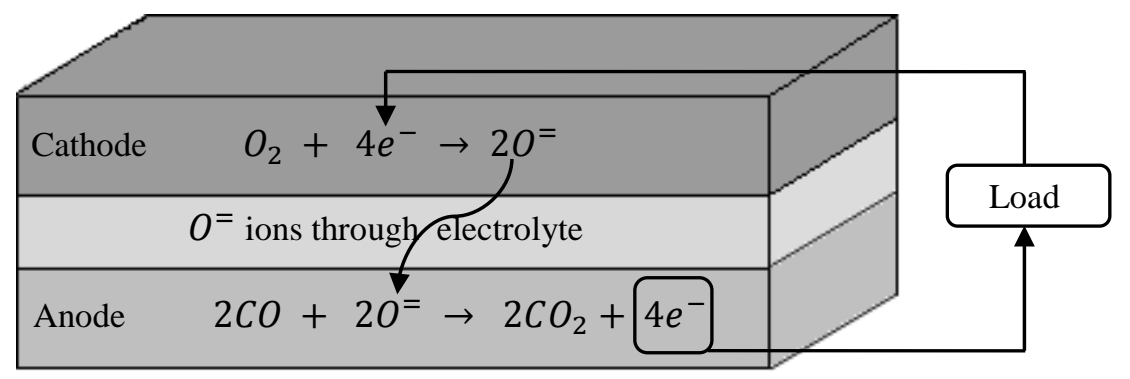

Figure 2.2. Diagram of $\mathrm{O}^{=}$transfer through the electrolyte during $\mathrm{CO}_{2}$ formation from $\mathrm{CO}$ on a SOFC.

The cell of a solid oxide fuel cell consists of a solid electrolyte between the anode and cathode. Most SOFCs are based on an electrolyte of zirconia that has been stabilized with the addition of a small amount of yttria $\left(\mathrm{Y}_{2} \mathrm{O}_{3}\right)$ [15]. This compound is referred to as YSZ. Zirconia becomes a conductor of doubly-ionized oxygen ions $\left(\mathrm{O}^{=}\right)$above temperatures of about $700^{\circ} \mathrm{C}$. This high operating temperature can present opportunities for combined cycle applications, but also presents challenges for the durability and construction of the fuel cell stack. Anode materials are typically a zirconia cermet with the metallic component being nickel. Nickel has high stability and electrical conductivity under chemically reducing conditions [15]. The use of nickel in the anode is also advantageous in that it can be used as a reforming catalyst, allowing direct internal reforming of hydrocarbons on the anode. This feature could help eliminate the need for an external fuel reformer. The cathode is usually made from a mixture of electronically conducting and ion-conducting ceramics. The most common cathode material of this type is strontium-doped lanthanum manganite [38]. This compound is referred to as LSM.

Walther Nernst (1864-1941) was the first to show that zirconia is ionically conductive but not electrically conductive at elevated temperatures [39]. This fact is the fundamental principle behind the operation of a solid oxide fuel cell. Nernst quantified this phenomenon into what is known as the Nernst Equation, 


$$
E=E^{0}-\frac{R T}{z F} \ln \frac{a_{R e d}}{a_{O x}}
$$

where

$E$ is the cell potential

$E^{0}$ is the standard cell potential at the temperature of interest

$R$ is the universal gas constant: $R=8.314472 \mathrm{JK}^{-1} \mathrm{~mol}^{-1}$

$T$ is the absolute temperature

$a$ is the chemical activity for the relevant species, where $a_{\text {Red }}$ is the reductant and $a_{O x}$ is the oxidant

$z$ is the number of electrons transferred in the cell reaction

$F$ is the Faraday constant, the number of coulombs per mole of electrons: $F=9.648534 \times 10^{4} \mathrm{C}$ $\mathrm{mol}^{-1}$

The Nernst equation can be used to find the theoretical cell potential as a function of cell temperature and partial pressures of the reactant gases at the anode and cathode under zero current, the open cell voltage (OCV).

Since doubly ionized oxygen is the mobile species in a SOFC, different fuels can be utilized at the anode. For example, not only hydrogen but also carbon monoxide (commonly found in syngas from coal or reformed fuels) can be used to generate electrons at the surface of the anode via a catalyst. The high operating temperature of a SOFC can allow for direct internal reforming of hydrocarbons at the anode, greatly increasing the overall process efficiency. There has been research into anodes that also reform hydrocarbons at the surface and such anodes are now making it possible to send gases such as methane and propane directly to a SOFC without the need for an upstream reforming reactor [7-8]. However, the presence of a carbonic species such as carbon monoxide or a hydrocarbon can lead to carbon deposition on the anode surface 
from the Boudouard reaction and hydrocarbon pyrolysis, shown in Equations 2.7 and 2.8, respectively:

$$
\begin{aligned}
& 2 \mathrm{CO} \rightarrow \mathrm{C}+\mathrm{CO}_{2} \\
& \mathrm{C}_{n} \mathrm{H}_{2 n+2} \rightarrow n \mathrm{C}+(n+1) \mathrm{H}_{2}
\end{aligned}
$$

The deposition of carbon on the anode can limit gas diffusion and catalysis and can also cause physical changes to the microstructure of the anode. This can be mitigated by humidifying the anode inlet stream or by directly injecting steam into the system [40]. Coincidentally, water is produced at the anode when hydrogen is utilized as a fuel. The steam reformation of hydrocarbons and carbon are processes which can help mitigate carbon formation during direct internal reforming and are shown in Equations 2.9 and 2.10, respectively:

$$
\begin{aligned}
& \mathrm{C}_{n} \mathrm{H}_{2 n+2}+\mathrm{nH}_{2} \mathrm{O} \rightarrow \mathrm{nCO}+(2 n+1) \mathrm{H}_{2} \\
& \mathrm{C}+\mathrm{H}_{2} \mathrm{O} \rightarrow \mathrm{CO}+\mathrm{H}_{2}
\end{aligned}
$$

\subsubsection{Cell Evaluation Methods}

There are two essential methods that are used to evaluate the performance of the fuel cell, specifically the anode. These two methods are potential-current-power density (V-I-P) diagrams and electrochemical impedance spectroscopy. The quantitative techniques allow the cell power output to be quantified, the cell electrochemical processes to be evaluated, and the cell circuitry limitations to be analyzed. 


\subsubsection{V-I-P Diagrams}

The most common method to measure the performance of a SOFC is the V-I curve. The plot is generated by collecting data points starting from the open circuit voltage (OCV) to the maximum allotted current density. A current is imposed upon the cell at differing intensities (zero current for the OCV) until all potential across the cell is exhausted. The units used on the $\mathrm{x}$-axis are voltage in volts (V). The units on the $\mathrm{y}$-axis are current density (current divided by effective cell surface area) and are typically in $\mathrm{mA} \mathrm{cm}^{-2}$. A typical V-I curve for a SOFC operating at about $800^{\circ} \mathrm{C}$ is shown in Figure 2.3.

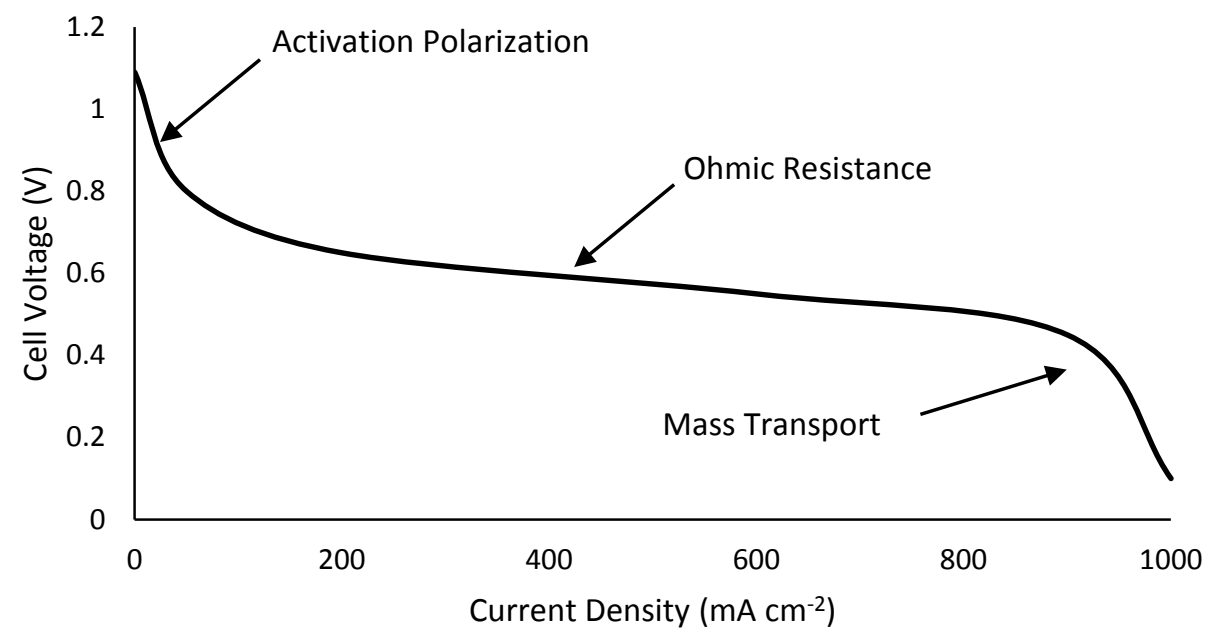

Figure 2.3. Graph showing the V-I curve for a typical SOFC operating at about $800^{\circ} \mathrm{C}$.

The characteristic shape of Figure 2.3 can be explained by the OCV and three major thermodynamic irreversibilities: activation losses, ohmic resistance, and mass transport or concentration losses. These irreversbilities can be used to characterize operational limitations of a fuel cell. 
When there is no current being drawn from the system, the observed potential is referred to as the open circuit voltage (OCV). The OCV is the result of the low partial pressure of oxygen at the anode in contrast to the cathode. Thermodynamic equilibrium will be established under steady-state conditions and the resulting equilibrium potential (also known as the OCV), can be found by Equation 2.11,

$$
E=\frac{-\Delta G_{f}}{z F}
$$

where $E$ is the OCV, $-\Delta G_{f}$ is the change in molar specific Gibbs free energy for formation, $z$ is the number of electrons transferred for each molecule of fuel, and $F$ is the Faraday constant. When the SOFC is operating at open circuit conditions, the measured potential should be the theoretical OCV. It is often the case that the measured voltage under open circuit conditions is less than the OCV and this has been attributed to leaks in the system.

Activation losses are caused by the limiting rates of the reactions occurring on the electrode surfaces and at the electrode/electrolyte interfaces. Voltage is lost due to the chemical reaction that is responsible for the transfer of electrons to or from the electrode. These charge transfers involve the conversion of a neutral species to an ion or the conversion of an ion to a neutral species. The voltage drop due to activation losses is non-linear and is related to the current density $i$ by Equation 2.12:

$$
\Delta V_{a c t}=A \ln \left(\frac{i}{b}\right)
$$

where $A$ and $b$ are constants that depend on the cell conditions and electrode microstructures. This equation only holds true when $i>b$. The voltage drop associated with activation losses can 
be reduced by raising the cell temperature, using a more effective catalyst, increasing the surface area of the electrodes, increasing the reactant concentration, and increasing the pressure [15].

The ohmic losses are due to the resistance to the flow of ions through the electrolyte and the electrical resistance of the electrodes and various interconnections. The voltage drop due to ohmic resistance is linearly proportional to the current density $i$ by Equation 2.13:

$$
\Delta V_{\text {ohm }}=i r
$$

where $r$ is the area-specific resistance and corresponds to $1 \mathrm{~cm}^{2}$ of the cell (to be consistent with the other equations for voltage loss in terms of current density). The main contributor to the ohmic losses is the electrolyte, due to the high ionic resistivity of YSZ. Changes in the ohmic resistance over time are usually due to increases in the resistance of the electrodes. The ohmic resistance can be decreased by making the electrolyte as thin as possible and by using electrodes with the highest possible electrical conductivity.

Mass transport losses in voltage are due to the diffusion limitations of the electrodes and the reduction of the reactant concentration in the region of the electrode, and hence are also known as concentration losses. The extent of the concentration loss depends on the circulation of the reactant at the electrode and how quickly it can be replenished and also on the current of the fuel cell. The consumption of the reactant at the electrode (for example, hydrogen at the anode and oxygen at the cathode) will cause a reduction in the partial pressure of the reactant. This reduction in gas pressure will consequently cause in a reduction in voltage. Although this phenomenon can be quantified mathematically on a theoretical basis, there is an empirical equation that fits experimental data very well:

$$
\Delta V_{\text {trans }}=m \exp (n i)
$$


where $i$ is the current density and $m$ and $n$ are constants. If the constants $m$ and $n$ are chosen properly, Equation 2.14 will provide a very good fit to experimental results [41-42]. The value of $m$ will typically be about $3 \times 10^{-5} \mathrm{~V}$ and $n$ about $8 \times 10^{-3} \mathrm{~cm}^{2} \mathrm{~mA}^{-1}[15]$.

Now that all of the components of the curve in the V-I diagram have been defined, an equation for the operating voltage of a fuel cell can be constructed in terms of the current density:

$$
\begin{aligned}
& V=E-\Delta V_{\text {ohm }}-\Delta V_{a c t}-\Delta V_{\text {trans }} \\
& V=E-i r-A \ln \left(\frac{i}{b}\right)-m \exp (n i)
\end{aligned}
$$

Power density curves are typically produced in conjunction with V-I curves and are plotted on the same graph to produce a V-I-P diagram. A characteristic V-I-P curve for a SOFC running on hydrogen at $800^{\circ} \mathrm{C}$ is shown in Figure 2.4.

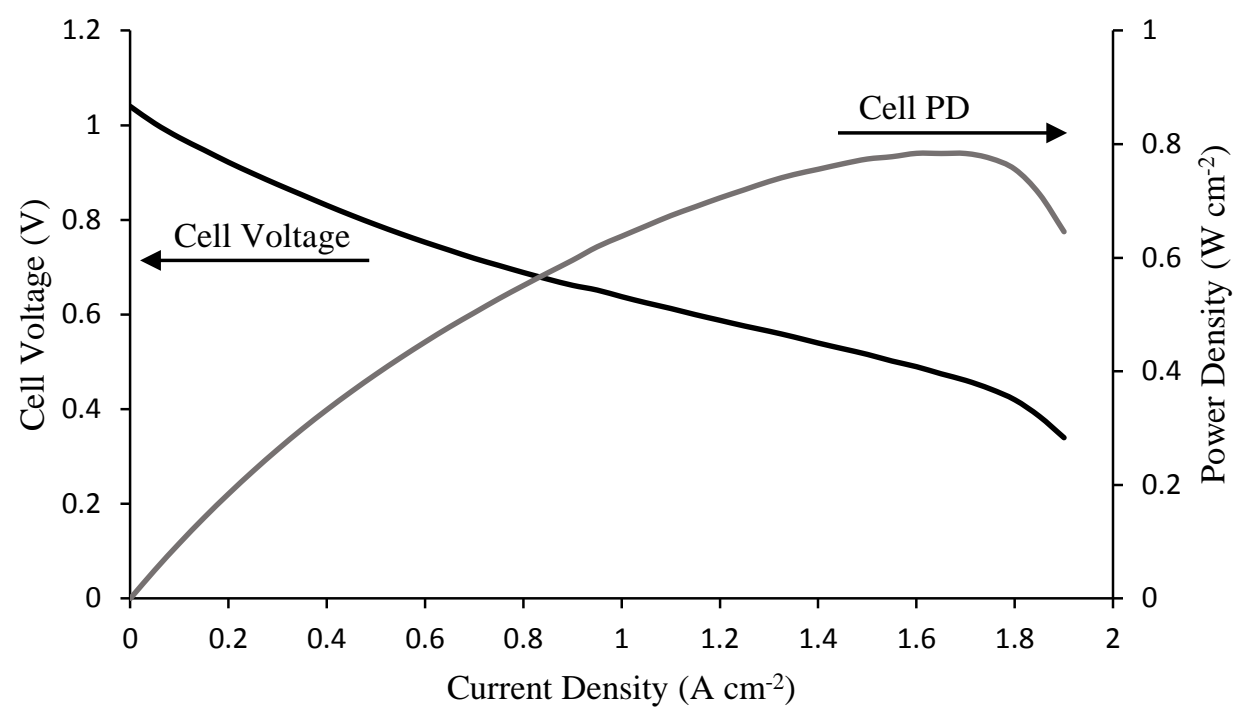

Figure 2.4. Characteristic V-I-P curve for a SOFC at $800^{\circ} \mathrm{C}$ on $\mathrm{H}_{2}$. 
The cell current density is plotted on the x-axis, the cell voltage is plotted on the primary $y$-axis, and the cell power density is plotted on the secondary y-axis. The curves are produced by imposing a set current upon the cell and then measuring the voltage. The current is increased until the cell can no longer produce a steady voltage (just shy of shorting-out the cell). Since the effective cell area is a known value, the current density can be calculated by dividing the current by the effective cell area. The power density is found by multiplying the cell voltage by the current density. The V-I-P diagram is used to characterize fuel cell performance as a function of current density and can be especially useful when comparing different fuels, operating conditions, or impurity testing.

\subsubsection{Electrochemical Impedance Spectroscopy}

Impedance spectroscopy is a technique of electrical characterization that allows the measurement of polarizations of electrochemical systems. The relaxation amplitudes and the characteristic time of the numerous processes in a dynamic system are revealed by small-signal perturbation over a wide range of frequencies. Due to the different sources of the kinetic processes involved with the thermodynamic irreversibilities listed previously, each polarization will exhibit a unique time dependence. For example, the response time for mass transport polarization is due to gas phase transport parameters such as diffusivity, meanwhile the response time for ohmic polarization is approximately zero [43].

Impedance spectra are typically displayed in a Nyquist plot. A characteristic Nyquist plot for a SOFC is illustrated in Figure 2.5. 


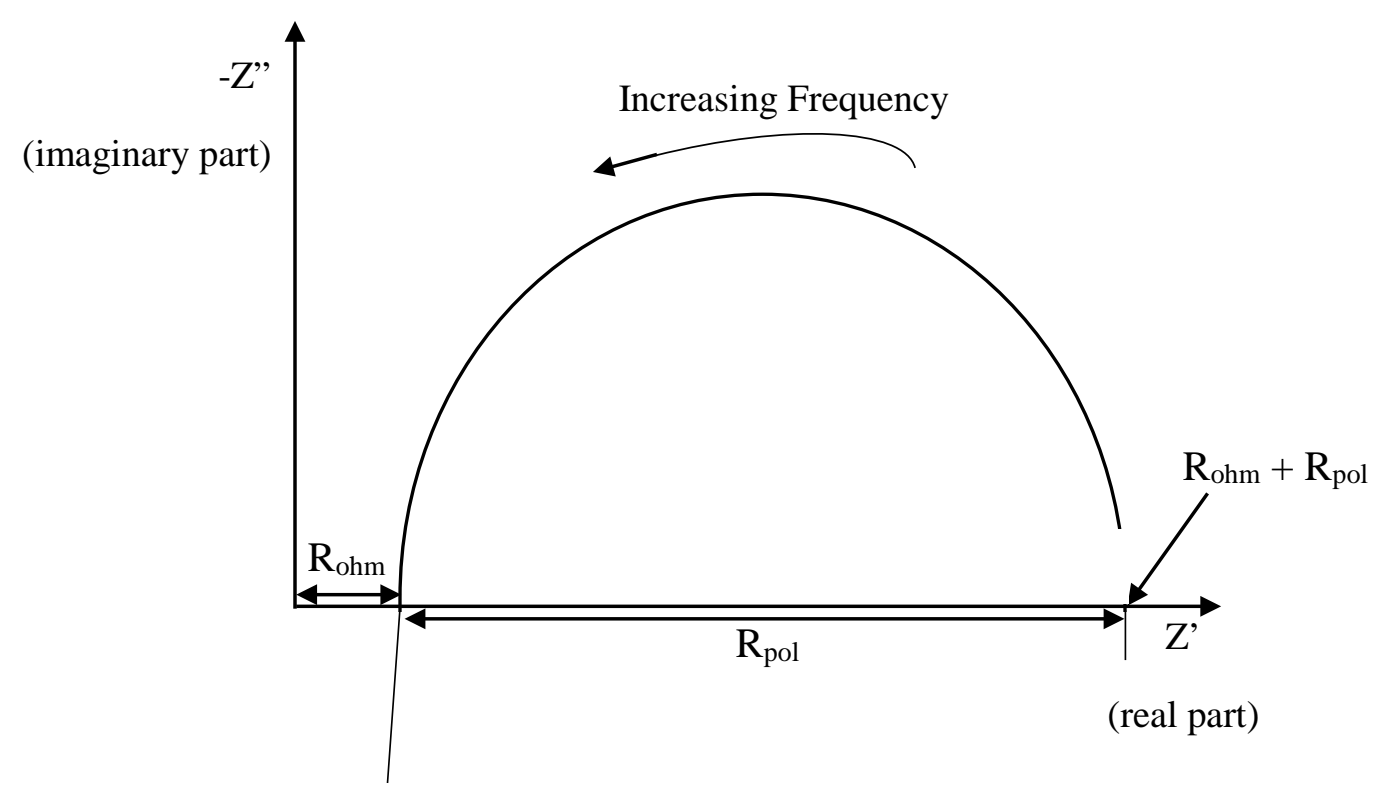

Figure 2.5. Characteristic Nyquist plot for a SOFC.

The information revealed by electrochemical impedance spectra (EIS) and displayed in a Nyquist plot is used to break down the total voltage lost on a single cell into its components. Typically a sinusoidal AC current or voltage which is varied for a range of frequencies on top of a DC bias is imposed upon the fuel cell to generate the EIS. Although there are many processes involved in the overall polarization losses, the spectra break down the total loss into ohmic resistance and polarization resistance. On the Nyquist plot, the x-axis represents the real part of the complex impedance and the $\mathrm{y}$-axis represents the imaginary impedance. Both the $\mathrm{x}$-axis and the y-axis typically have units of $\Omega \mathrm{cm}^{2}$. The intersection of the spectra with the x-axis on the left side of the plot represents the value of the ohmic resistance of the cell for a zero time response. This is due to the fact that the ohmic resistance has constant impedance independent of the frequency [44]. The processes that occur at the highest frequencies are represented by spectra on the left side of the plot and the processes that occur at the lowest frequencies are 
represented by spectra on the right side of the plot, therefore frequency increases from right to left. Also the process speeds are higher for spectra on the left side of the plot as opposed to slower process speed for spectra on the right side of the plot. The mechanisms that are the under-lying causes to the resistances change as a function of imposed frequency, and in effect, their response times differ. The high frequency response is due to charge transfer during the chemical and electrochemical reactions and electron transport processes in an SOFC and is related to the activation overpotentials. The frequency for these types of processes typically ranges from $10^{3}-10^{8} \mathrm{~Hz}$ [44]. The low-frequency response is a result of the gas diffusion difficulties to the electrode surfaces. This occurs at frequencies of about $0.05 \mathrm{~Hz}-10^{3} \mathrm{~Hz}$ [44]. The total cell resistance is equal to the ohmic resistance plus the polarization resistance.

It is important to measure the impedance of the cell at multiple points in time while conducting long-term performance runs or chemical impurity testing. Any change in the impedance of the cell can correspond to poisoning or deactivation of the anode. The impedance spectra can help to diagnose changes to the cell structure and assess possible degradation mechanisms while the fuel cell is still on-line and operating. 


\subsection{Overview of Reforming}

The chemical reactions that convert a liquid hydrocarbon to hydrogen and carbon monoxide are collectively referred to as reforming reactions. The three following reactions are the main catalytic reforming reactions that are involved in the conversion of hydrocarbon fuels into synthesis gas for fuel cells:

$$
\begin{array}{ll}
\text { Catalytic Partial Oxidation (CPOX) } & \mathrm{C}_{n} \mathrm{H}_{m}+\frac{n}{2} \mathrm{O}_{2} \rightarrow n \mathrm{CO}+\frac{m}{2} \mathrm{H}_{2} \\
\text { Steam Reforming (SR) } & \mathrm{C}_{n} \mathrm{H}_{m}+n \mathrm{H}_{2} \mathrm{O} \rightarrow n \mathrm{CO}+\left(n+\frac{m}{2}\right) \mathrm{H}_{2} \\
& \mathrm{C}_{n} \mathrm{H}_{m}+\mathrm{H}_{2} \mathrm{O}+\mathrm{O}_{2} \rightarrow \mathrm{CO}+\mathrm{H}_{2}
\end{array}
$$

The hydrocarbon fuel is oxidized in Equations 2.17-2.19 to produce synthesis gas that has a high concentration of hydrogen [45]. It should be noted that $\mathrm{CO}_{2}$ and $\mathrm{H}_{2} \mathrm{O}$ are also products of these reactions but were omitted for simplification, as $\mathrm{CO}$ and $\mathrm{H}_{2}$ are the oxidizable fuels of interest for SOFCs. Oxidative steam reforming is a case of reforming involving both SR and $\mathrm{CPOX}$. Steam reforming is an endothermic reaction, thus requiring a net energy input. CPOX is exothermic and does not require a net energy input, meaning the reforming reactor has less stringent heat transfer demands when compared to SR and OSR.

Hydrogen can also be produced from carbon monoxide and water non-catalytically via the equilibrium-controlled exothermic water-gas shift reaction.

Water-Gas Shift (WGS) $\quad \mathrm{CO}+\mathrm{H}_{2} \mathrm{O} \leftrightarrow \mathrm{CO}_{2}+\mathrm{H}_{2}$

Catalytic reforming reactors typically operate in the temperature range of $600^{\circ} \mathrm{C}$ to $1000^{\circ} \mathrm{C}$, depending on the catalyst, fuel, and the type of reforming utilized [46-47]. These 
temperatures are close to the $\sim 800^{\circ} \mathrm{C}$ operating temperature of SOFCs, and can allow opportunity for direct utilization of its hot reformate with little or no additional thermal processing, provided the gas does not need to be cleaned.

Since the major reactions for the reforming of hydrocarbons are catalytic, the reformer catalyst is a vital component of the fuel processing system for SOFC applications. The catalyst must be chosen properly for activity and selectivity for the fuel being used. Furthermore, the reforming process must have a high selectivity for $\mathrm{H}_{2}$ and $\mathrm{CO}$ while maintaining a high conversion of the hydrocarbon to be effective enough for use in a SOFC. The catalyst must also have chemical stability in the oxidizing reaction environment and resist sintering and especially poisoning and coking under the various pressure, temperature, and flow changes it might incur during operation $[10,48]$.

\subsection{Catalysts Utilized for Fuel Reforming}

Typical reforming catalysts include mixed metal oxides or metals such as nickel, rhodium, bimetallics, or platinum incorporated onto an oxide substrate with a high surface area such as $\gamma-\mathrm{Al}_{2} \mathrm{O}_{3}$ or $\mathrm{SiO}_{2}$ for the catalytic partial oxidation of liquid hydrocarbon fuels [24, 50].

The majority of liquid fuels contain many chemical species and some of those species may have damaging effects on not only the catalysts, but also the rates of CPOX reactions [49]. Some species may adsorb to active metal sites more strongly than others, thereby reducing reaction rates of other species. Attempts to increase reaction rates and decrease carbon deposition by increasing temperature may inadvertently cause active metal vaporization or excessive sintering [45]. Sulfur is present in most hydrocarbon fuels and it has been found that sulfur-containing 
species cause reforming catalysts to deactivate, and thus there has been much research into sulfur-tolerant catalysts for the CPOX of liquid fuels [24-25, 36, 48-51].

\subsubsection{NETL Reforming Catalyst Development}

Some of the catalysts currently being researched and developed by the NETL in Morgantown, West Virginia are mixed metal oxides based on the pyrochlore structure. A derivative of the fluorite structure, a pyrochlore is a mixed oxide with equal amounts of trivalent and tetravalent cations in a cubic unit cell structure. Pyrochlores have the general stoichiometry of $\mathrm{A}_{2} \mathrm{~B}_{2} \mathrm{O}_{7}$ [58]. The trivalent A-site cation, the larger of the two cations, is usually a rare earth element and is coordinated with eight oxygen anions. The tetravalent B-site cation is typically a transition metal, must have an ionic radius smaller than the A-site cation, and is coordinated with six oxygen anions. The ionic radius ratio of the A-site and B-site cations must be between 1.4 and 1.8 for the stable formation of a pyrochlore [59]. The $\mathrm{A}_{2} \mathrm{~B}_{2} \mathrm{O}_{7}$ pyrochlore structure is shown in Figure 2.6:

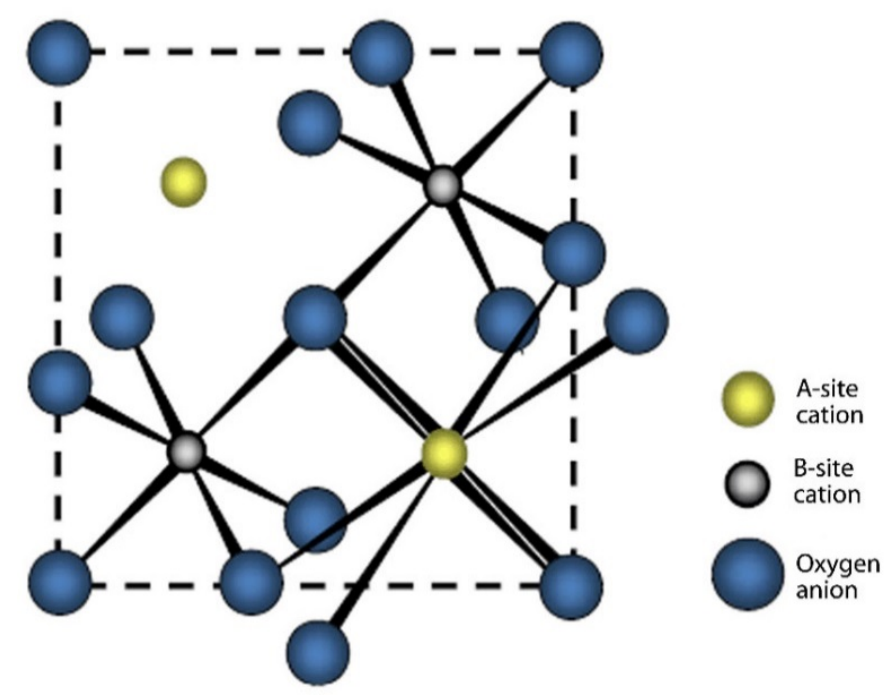

Figure 2.6. $A_{2} B_{2} O_{7}$ pyrochlore structure. Adapted from [50]. 
The lanthanum zirconate, $\mathrm{La}_{2} \mathrm{Zr}_{2} \mathrm{O}_{7}$ (LZ), pyrochlore was chosen as a catalyst for CPOX. LZ has shown high thermal and chemical stability [60-62] and also can be substituted with metals that increase oxygen ion conductivity, based on its mechanical strength [62]. A study was conducted to assess different LZ catalysts for the CPOX reforming reaction. LZ was compared to two different catalysts: LZ substituted with Rh only and LZ substituted with Rh and $\mathrm{Sr}$ [50]. The catalysts were characterized using X-ray diffraction (XRD), temperature programmed reduction (TPR), $\mathrm{H}_{2}$ pulse chemisorption, and CPOX activity measurements. These characterization tests were performed for confirmation of Rh metal substitution into the $\mathrm{LZ}$ structure and to formulate a relationship between the chemical and physical properties of the substituted metal with reforming activity [50]. The three pyrochlore catalysts were prepared by a modified Pechini method using the metal nitrates $\mathrm{La}\left(\mathrm{NO}_{3}\right)_{2} \cdot 6 \mathrm{H}_{2} \mathrm{O}, \mathrm{ZrO}\left(\mathrm{NO}_{3}\right)_{2} \cdot n \mathrm{H}_{2} \mathrm{O}, \operatorname{Sr}\left(\mathrm{NO}_{3}\right)_{2}$, and $\mathrm{Rh}\left(\mathrm{NO}_{3}\right)_{3} 2 \mathrm{H}_{2} \mathrm{O}$, which is described in the literature [50, 63-66]. The composition of the catalysts is listed as $\mathrm{La}_{2} \mathrm{Zr}_{2} \mathrm{O}_{7}$ (LZ), $\mathrm{La}_{2} \mathrm{Rh}_{0.11} \mathrm{Zr}_{1.89} \mathrm{O}_{7-\mathrm{y}}$ (LRZ), and $\mathrm{La}_{1.5} \mathrm{Sr}_{0.5} \mathrm{Rh}_{0.10} \mathrm{Zr}_{1.90} \mathrm{O}_{7-\mathrm{y}}$ (LSRZ), with oxygen adjustment (y) of 0.055 and 0.30 for LRZ and LSRZ, respectively. The Rh content of LRZ and LSRZ is listed as $2.0 \mathrm{wt} \%$ [50]. The three pyrochlore catalysts along with a commercial $0.5 \mathrm{wt} \% \mathrm{Rh} / \gamma-\mathrm{Al}_{2} \mathrm{O}_{3}$ catalyst were used to reform $n$-tetradecane under $\mathrm{CPOX}$ conditions for 5 hours and the product yields and accumulated carbon are listed in Table 2.1.

Equation 2.21 was used to solve for the product yield of each gas species:

$$
\text { Yield of } X(\%)=\frac{\text { Moles of } X \text { produced } \times i \times 100}{n \times \text { moles of TD fed to the reactor }}
$$

were $X$ is the species of interest, $n$ is the number of moles of carbon in the hydrocarbon fuel or the number of moles of $\mathrm{H}_{2}$ per mole of hydrocarbon, and $i$ is the number of moles of carbon per mole of hydrocarbon in the product. 
Table 2.1. Product yields and carbon deposited for $\mathrm{Rh} / \gamma-\mathrm{Al}_{2} \mathrm{O}_{3}$ and pyrochlores after 5 hour reforming of $\mathrm{TD}$ at $\mathrm{O} / \mathrm{C}_{\mathrm{A}}=1.2,900^{\circ} \mathrm{C}, 0.23 \mathrm{MPa}$, and 50,000 scc gcatalyst $^{-1} \mathrm{hr}^{-1}$. Adapted from [50]

\begin{tabular}{|c|c|c|c|c|}
\hline & $\mathrm{Rh} / \gamma-\mathrm{Al}_{2} \mathrm{O}_{3}$ & $\mathrm{LZ}$ & $\mathrm{LRZ}$ & $\mathrm{LSRZ}$ \\
\hline $\mathrm{H}_{2}$ yield (\%) & 85 & 65 & 83 & 86 \\
\hline $\mathrm{CO}$ yield (\%) & 79 & 68 & 83 & 89 \\
\hline $\mathrm{CO}_{2}$ yield (\%) & 20 & 21 & 7.0 & 7.0 \\
\hline $\mathrm{CH}_{4}$ yield (\%) & 1.0 & 8.0 & 5.0 & 1.0 \\
\hline Olefin yield (\%) & 0.2 & 3.0 & 1.0 & 0.0 \\
\hline $\begin{array}{c}\text { Carbon accumulated } \\
\text { (gcarbon/gcatalyst) }\end{array}$ & 0.27 & 0.29 & 0.32 & 0.17 \\
\hline
\end{tabular}

As seen in Table 2.1, the LSRZ pyrochlore catalyst had the highest selectivity toward $\mathrm{H}_{2}$ and CO, fuels that are of particular interest for use in SOFCs. Also, the LSRZ had the lowest amount of carbon accumulated of the four catalysts.

A second study was conducted on the commercial $0.5 \mathrm{wt} \% \mathrm{Rh} / \gamma-\mathrm{Al}_{2} \mathrm{O}_{3}$ catalyst and the three pyrochlore catalysts (LZ, LRZ, and LSRZ) to determine the effects of sulfur contaminants in the liquid fuel feed. The four catalysts were brought to stable reforming conditions under $n$ tetradecane (TD) for one hour, then were exposed to TD that contained $1000 \mathrm{ppmw}$ dibenzothiophene (DBT) for 2 hours, and then the feed was returned to TD for one hour to establish catalyst recovery [25]. It was found that the addition of the DBT to TD resulted in a loss of reforming activity for each catalyst. The $0.5 \mathrm{wt} \% \mathrm{Rh} / \gamma-\mathrm{Al}_{2} \mathrm{O}_{3}$ and the $\mathrm{LZ}$ underwent immediate deactivation by the DBT, whereas the LRZ and LSRZ displayed a gradual activity loss, with the LSRZ showing the smallest decrease in activity [25]. The amount of carbon formed on each catalyst as measured by temperature programmed oxidation (TPO) is listed in Table 2.2: 
Table 2.2. Amount of carbon formed on $0.5 \mathrm{wt} \% \mathrm{Rh} / \gamma-\mathrm{Al}_{2} \mathrm{O}_{3}$ and pyrochlore catalysts (LZ, LRZ, and LSRZ) at end of $5 \mathrm{hr}$ sulfur experiment at $\mathrm{O} / \mathrm{C}=1.2,50,000 \mathrm{scc}_{\text {catalyst }^{-1}} \mathrm{hr}^{-1}, 0.23 \mathrm{MPa}$ and $900^{\circ} \mathrm{C}$. Adapted from [25].

\begin{tabular}{|c|c|}
\hline Catalyst & $\begin{array}{c}\text { Carbon deposition } \\
\text { (gcarbon/gatalyst) }\end{array}$ \\
\hline $\mathrm{Rh} / \gamma-\mathrm{Al}_{2} \mathrm{O}_{3}$ & 0.90 \\
\hline $\mathrm{LZ}$ & 0.80 \\
\hline $\mathrm{LRZ}$ & 0.86 \\
\hline $\mathrm{LSRZ}$ & 0.30 \\
\hline
\end{tabular}

As seen in Table 2.2, all catalysts showed more carbon formation during the sulfur experiments than compared to the CPOX of TD-only experiments [50] (shown in Table 2.1). The $\mathrm{Rh} / \gamma-\mathrm{Al}_{2} \mathrm{O}_{3}, \mathrm{LZ}$, and LRZ had similar amounts of carbon formation, however, the LSRZ had significantly less carbon deposited. It was found that each catalyst was able to recover some activity after the sulfur-containing DBT was removed from the feed. The $0.5 \mathrm{wt} \% \mathrm{Rh} / \gamma-\mathrm{Al}_{2} \mathrm{O}_{3}$ showed the least amount of recovery, the LZ showed some recovery but was much less than initial levels, the LRZ was able to regain most of its initial levels, and the LSRZ recovered to almost initial activity levels [25]. It was suggested from these results that the $0.5 \mathrm{wt} \% \mathrm{Rh} / \gamma$ $\mathrm{Al}_{2} \mathrm{O}_{3}$ showed the least amount of recovery due to larger amounts of carbon on the active metal, and the LRZ showed better recovery than the LZ as a result of less carbon formation on the active sites [25]. Also, the substitution of Sr into the LRZ structure, creating oxygen vacancies in the pyrochlore lattice, promoted oxygen ion conductivity and thus reduced the deactivation of catalyst by carbon deposition and by sulfur [25].

Given these favorable results, the LSRZ catalyst developed by the NETL in Morgantown, West Virginia was chosen as the catalyst for the reforming studies conducted in this work. 


\section{Experimental Work}

The experimental apparatus that includes the fuel vaporization system, humidifier, reforming reactor, reforming catalyst, the button cell of the SOFC, and the SOFC testing system will be described in this chapter. The experimental methods and the operating conditions for the equipment will also be defined. The equipment used for controlling the processes and taking measurements will be listed. Finally, the description and origin of the liquid fuels that were tested will be provided.

\subsection{Experimental Setup}

Figure 3.1 shows a simplified block illustration of the reformer/fuel cell system. The liquid fuel was pumped into a heated furnace containing the vaporization system and then combined with a nitrogen carrier gas. Next the vaporized fuel stream combined with a humidified air stream before entering the reforming reactor, which was contained within a second heated furnace within the first heated furnace. The mixture of fuel vapor, nitrogen, and humidified air entered the reforming reactor and were acted upon by a catalyst, which facilitates chemical reactions, and yields a mixture of gases that were sent to the anode of the solid oxide fuel cell. The fuel cell was contained within another heated tube furnace. Nitrogen and hydrogen streams could be selectively connected to the anode inlet of the fuel cell for purging, reducing, and initial testing of the cell. Dry air was fed to the cathode inlet at the top of the fuel cell. The fuel gas mixture was exhausted from the fuel cell after passing across the anode of the cell. Similarly, the air that passed over the cathode of the cell was exhausted from the fuel cell in a separate stream. A current load was imposed across the cell by means of an electronic load cell 
(TDI Power, Model no. SDL 1103), drawing an electrical current that can be adjusted according to reaction and fuel cell conditions.

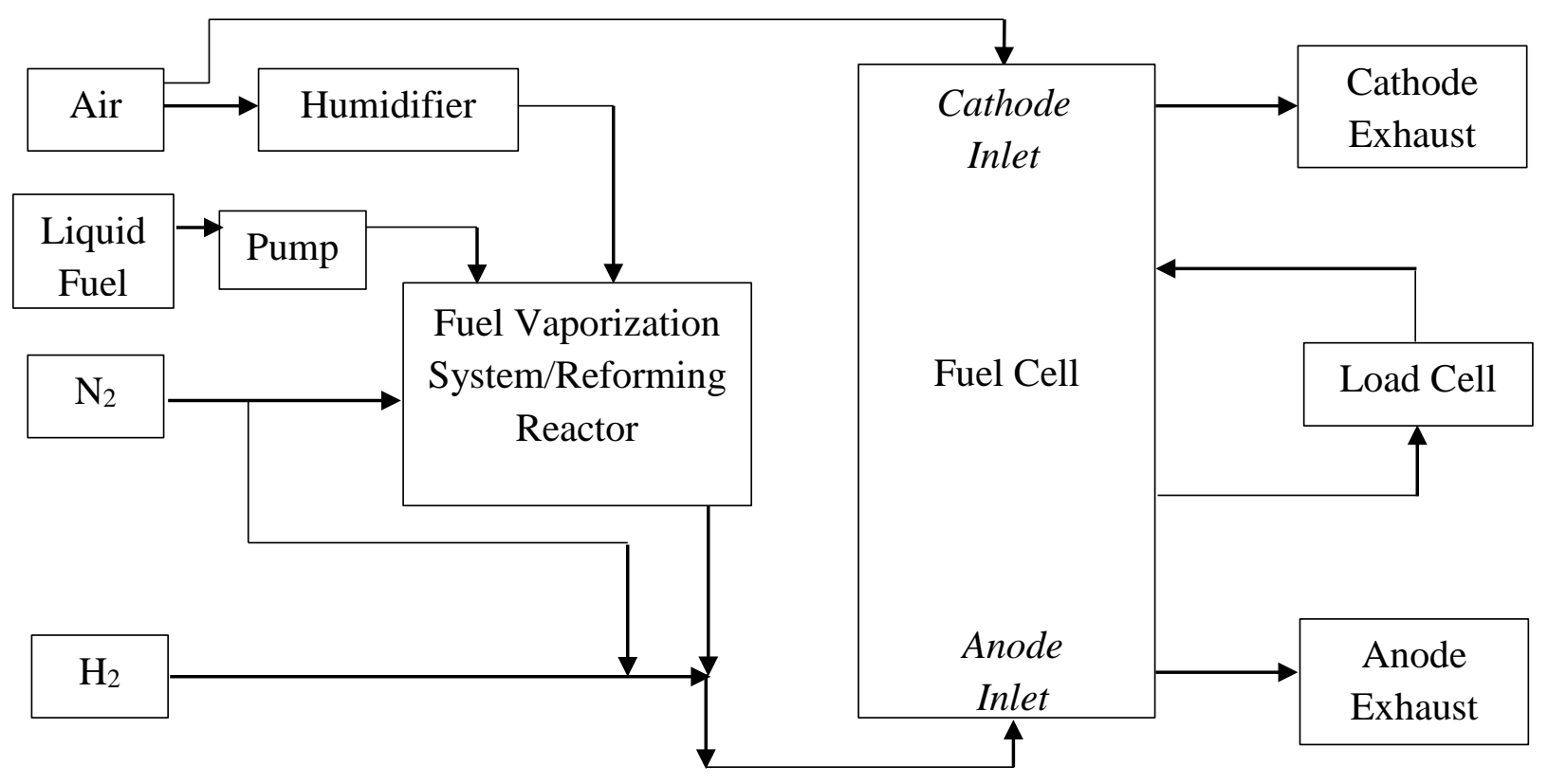

Figure 3.1. Block flow diagram of reformer/fuel cell system.

\subsubsection{Fuel Vaporization System and Humidifier}

Figure 3.2 illustrates the configuration of the fuel vaporization system, humidifier, and reactor. The liquid fuel was pumped at a constant flow rate into the vaporization system using a high accuracy HPLC pump (Dionex Corp., Model no. P680A HPG). The fuel line was small enough that the fuel was introduced drop-wise into the heated tubing, having sufficient residence time to vaporize. A nitrogen gas stream was heated through a coil of tubing and carried the fuel through the vaporization system. Air was sent through a heated humidifier containing deionized 
water. A thermocouple and a pressure gauge were inserted in the humidifier to measure the water temperature and vapor pressure, respectively. The air passed through a diffusion stone, become humidified, and then combined with the vaporized fuel/nitrogen mixture within the vaporization system. Similar to the nitrogen gas stream, the humidified air stream was also heated through a coil of tubing prior to being combined with the vaporized fuel stream. The line for the humidified air stream was insulated and heated with heating tape between the humidifier and the furnace containing the vaporization system to prevent condensation of water in the line. The combined gas stream consisting of the vaporized fuel, nitrogen, oxygen and water was then sent to the reforming reactor.

The reforming reactor was placed in Furnace A (Series 3210 split tube furnace, Applied Test Systems, Inc.) which kept the reaction zone at the desired reaction temperature $\left(900^{\circ} \mathrm{C}\right)$. Furnace A was operated by a programmable temperature controller (Eurotherm, Model no. 2416). As shown in Figure 3.2, Furnace A was installed inside another furnace, Furnace B (Fisher Scientific, Model no. 750-58 Isotemp Programmable Forced-Draft Furnace). Furnace B held the temperature of the entire system above the vaporization temperature of the liquid fuel $\left(\sim 375^{\circ} \mathrm{C}\right)$ and therefore contained a tubing system sufficient enough to allow the liquid fuel to be vaporized and heat all the gases before entering the reformer. A thermocouple was inserted in Furnace B to measure its temperature. The nitrogen and dry air were supplied by gas cylinders located in the laboratory. The flow rates of the nitrogen and dry air streams were controlled by mass flow controllers (Alicat Scientific, 16 Series Mass and Volumetric Precision Gas Flow Controller).

For safety reasons, a system of valves was incorporated to shut off the gas flows when necessary. Also, a three-way valve was installed after the humidifier to allow the humidified air 
stream to be drained. A three-way valve was installed on the fuel line before Furnace B to allow the line to be purged. Another three-way valve was installed after the reactor outlet before the inlet to the SOFC anode to allow for sample collection or venting to the atmosphere during startup.

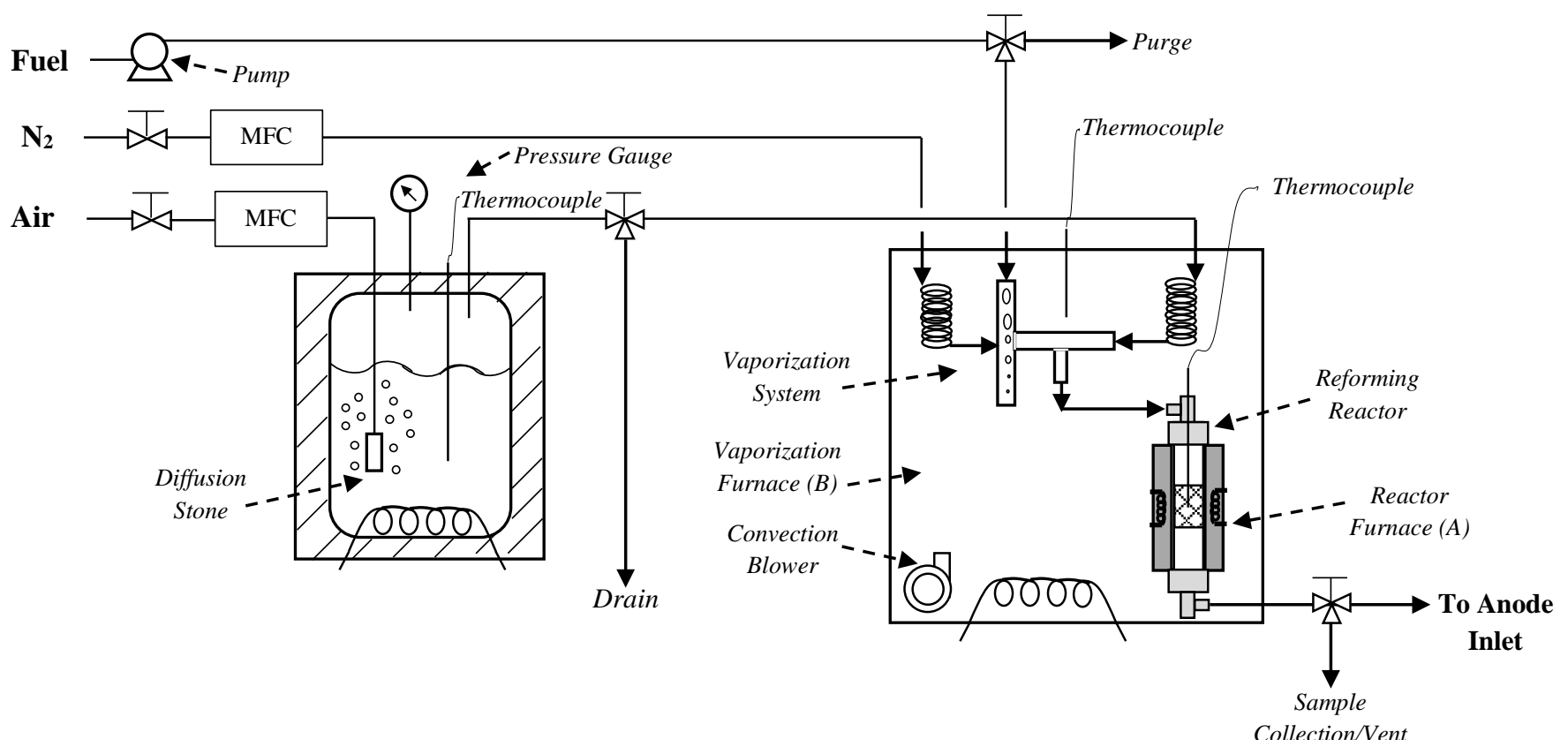

Figure 3.2. Diagram of fuel vaporization system, humidifier, and reactor.

\subsubsection{Reforming Reactor}

The reforming reactor was made of the high-temperature nickel alloy Incoloy-HT. The reactor had three internal sections: A pre-catalyst mixing zone comprised of sieved, pure silica sand (-20 +40 mesh), the reaction zone comprised of a mixture of catalyst and silica sand, and a post-catalyst mixing zone comprised of silica sand. The catalyst bed containing the catalyst was diluted by 5/1 by weight with silica sand to avoid hot spots and channeling. Quartz wool was 
placed in the stainless steel fittings to keep the sand in the reactor tube and also at both sides of the catalyst bed to prevent catalyst from leaving the reaction zone. A coaxially centered type $\mathrm{K}$ thermocouple was inserted into the reactor such that the tip is centered in the reaction zone. The reactor furnace (Furnace A) was operated at $900^{\circ} \mathrm{C}$. A diagram of the reforming reactor is shown in Figure 3.3; however, the actual positioning of the reactor was vertically oriented, with the reactor inlet at the top (as shown in Figure 3.2).

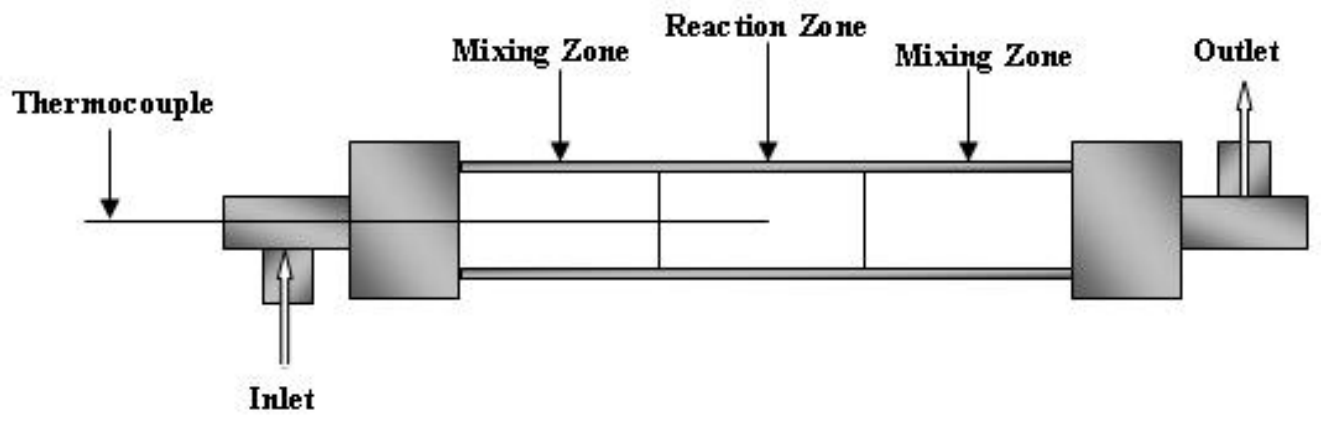

Figure 3.3. Diagram of reforming reactor.

\subsubsection{Solid Oxide Fuel Cell Structure and Composition}

A commercial anode-supported solid oxide button cell manufactured by Materials and Systems Research, Inc. (MSRI) was used. The cell consisted of five layers: (1) 0.8 0.9 mm thick Ni-8YSZ anode layer which supported the cell structure, (2) 25- $\mu$ m thick highly catalytic Ni-8YSZ mixture interlayer, (3) 20- $\mu$ m thick 8YSZ (YSZ) electrolyte, (4) 25- $\mu$ m thick $\mathrm{La}_{0.8} \mathrm{Sr}_{0.2} \mathrm{MnO}_{3}$ (LSM)-8YSZ interlayer, and (5) 50- $\mu \mathrm{m}$ thick current-collection cathode layer made of LSM. The effective area of the cell (cathode area) was $2 \mathrm{~cm}^{2}$. A platinum current collection mesh was attached across the cathode using platinum paint. A pair of platinum current collection meshes separated by $0.5 \mathrm{~cm}$ was attached symmetrically on the anode using nickel 
paste. Thus, the center of the anode was directly exposed to the injected fuel without any intervening current collector or metal paste. This is shown schematically in Figure 3.4. The two ends of the cathode and two ends of the anode current collection meshes were connected by thick silver wires; in addition, two thin voltage-sensing wires were connected to the cathode and anode current collection meshes. The thick wires were used to draw current from the cell while the thin wires were employed to measure the cell voltage with a high-impedance voltmeter.

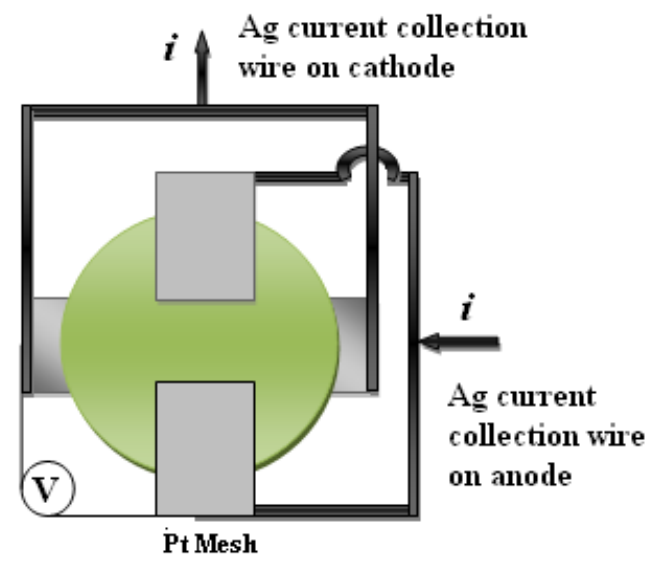

Figure 3.4. Button cell contact configuration on the anode of the MSRI SOFC.

\subsubsection{Solid Oxide Fuel Cell Testing System}

Figure 3.5 shows a diagram of the fuel cell test stand. It should be noted that the fuel cell can be operated on reformate or pure hydrogen gas for comparison. A three-zone tube furnace (Lindberg Blue M, Model no. 55347) was used, with the cell positioned in the center of the middle heating zone. The furnace was controlled by a programmable temperature controller (Eurotherm, Model no. 818S). The cathode inlet was at the top of the fuel cell system and the anode inlet was at the bottom of the fuel cell system. Dry air passed through a valve and a mass 
flow controller (Alicat Scientific, 16 Series Mass and Volumetric Precision Gas Flow Controller) on its way to the cathode inlet at the top of the fuel cell system. Concentric ceramic tubes were interfaced with specially configured stainless steel tubing with graphite gaskets at the inlets and a ceramic flange system with mica washers at the cell. The cell was situated between two ceramic flanges that allowed the proper orientation of the inlet and outlet tubes at the faces of the cell. The ceramic inlet tubing was mounted concentrically within the ceramic outlet tubing. This configuration allowed for thermal integration as the cooler inlet gases were heated by the hot effluent gases by the countercurrent flow. Also, this configuration allowed the inlet gases to impinge directly on the center of the cell. The outlet gases were exhausted without coming in contact with the inlet gases. A thermocouple was inserted through the cathode inlet ceramic tubing all the way down to the face of the cathode surface of the cell. This allowed for the temperature of the cell to be monitored at a location very near the surface of the cathode. As mentioned in section 3.1.3, there were wire leads connected to the cell to allow for the voltage to be monitored and a current load to be imposed upon the cell. These wire leads were brought out of the bottom of the furnace and were connected to the measurement equipment. 


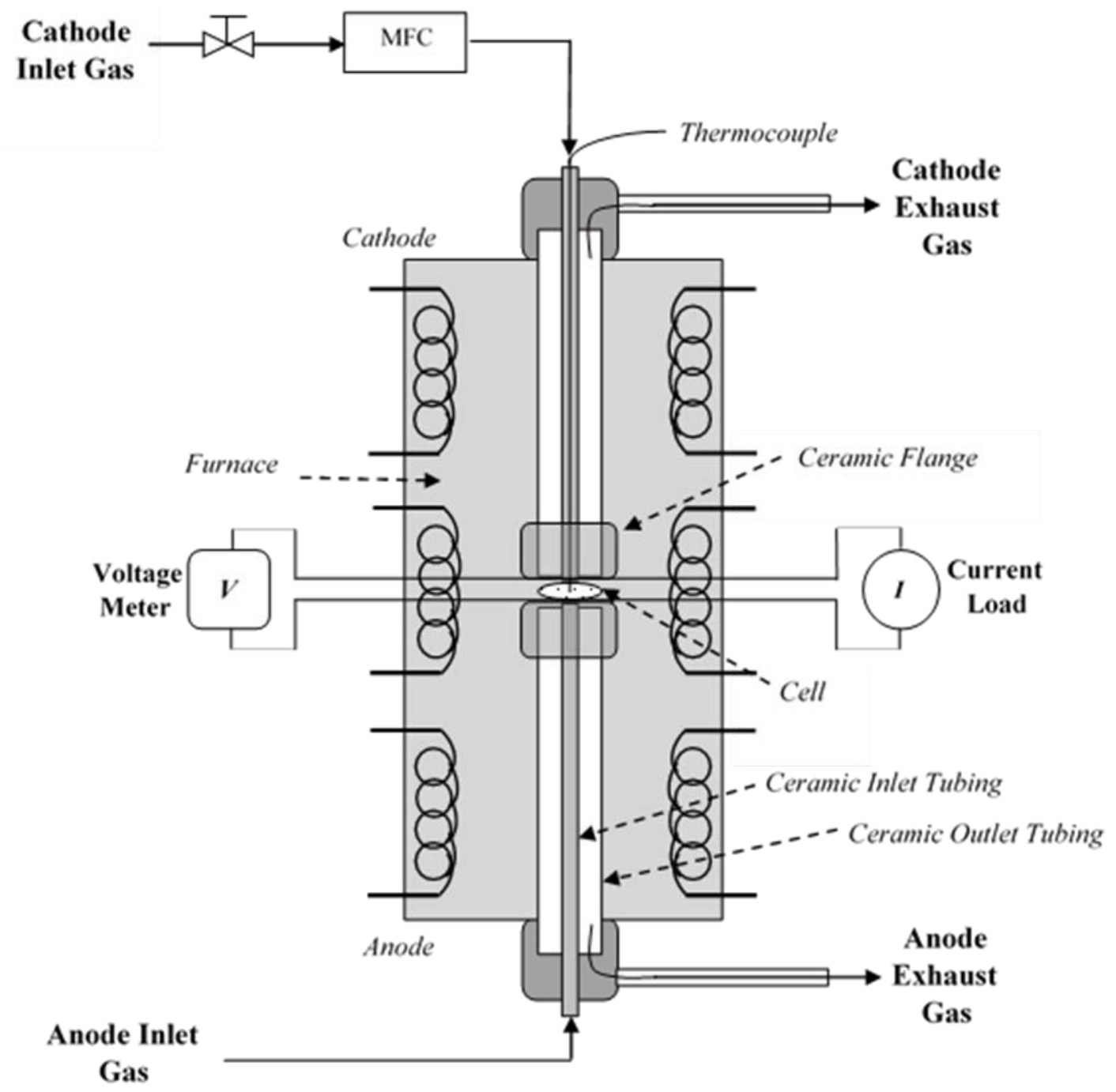

Figure 3.5. Diagram of the solid oxide fuel cell system. 


\subsection{Reforming Catalysts}

Two different reforming catalysts were used during this work. The first was a commercially available catalyst for initial testing of the fuel reforming reactor. The second catalyst was a novel catalyst that was developed through extensive research by the U.S. Department of Energy's National Energy Technology Laboratory (NETL) in Morgantown, West Virginia.

\subsubsection{Commercial Rhodium on Alumina $\left(\mathrm{Rh} / \gamma-\mathrm{Al}_{2} \mathrm{O}_{3}\right)$}

This catalyst sample was purchased from Alfa Aesar and consisted of $0.5 \mathrm{wt} \%$ rhodium incorporated onto $3 \mathrm{~mm}$ pellets of the high surface area substrate $\gamma-\mathrm{Al}_{2} \mathrm{O}_{3}$. Rhodium was chosen as the active metal due to its high selectivity to $\mathrm{H}_{2}$ and $\mathrm{CO}$, and has been identified as a superior metal for CPOX when compared to platinum [55-57]. However, this commercial catalyst is susceptible to sulfur poisoning [25] and was therefore only used to validate proper operation of the reformer/SOFC system using a sulfur-free liquid fuel.

\subsection{2. $\quad \operatorname{NETL~} \operatorname{La}(2-x) \operatorname{Sr}_{x} \operatorname{Rh}_{y} Z r_{(2-y)} \mathbf{O}_{(7-\xi)}(\operatorname{LSRZ})$}

The second catalyst in this study was provided by the NETL in Morgantown, West Virginia. This catalyst was developed through extensive research by the NETL (described in Chapter 2). The LSRZ catalyst is a mixed metal oxide based on the pyrochlore structure. It consists of strontium substituted for a portion of lanthanum in the lanthanum-rhodium-zirconate pyrochlore (LRZ) structure to yield a new catalyst with the chemical formula $\mathrm{La}_{(2-x)} \operatorname{Sr}_{x} \operatorname{Rh}_{y} \operatorname{Zr}_{(2-y)} \mathrm{O}_{(7-\xi)}$ (LSRZ) [50]. The substitution of Sr into the LRZ structure yielded a 
binary perovskite-pyrochlore phase with a defect $\mathrm{SrZrO}_{3}$ phase [50]. Haynes, et al. (2008) showed that the Rh substituted in the LSRZ was able to produce near-equilibrium syngas yields while maintaining chemical activity [50]. The LSRZ catalyst was used under catalytic partial oxidation (CPOX) conditions to reform $n$-tetradecane into synthesis gas with the amount of carbon formation equal to $0.17 \mathrm{~g}$ carbon $/ \mathrm{g}_{\text {catalyst, }}$ as shown by temperature programmed oxidation (TPO) experiments after the run, which was significantly less than prior catalyst species tested [50].

\section{3. $\quad$ Low-Sulfur Liquid Fuels}

Various liquid hydrocarbon fuels were tested. The fuels were chosen due to their use as logistics fuels or similarity to logistics fuels. Reactor flow calculations changed according to the liquid fuel being used and their differing chemical composition. The two sulfur-free liquid fuels and three sulfur containing liquid fuels were tested in the reformer/SOFC system. The two sulfur-free liquids tested were $n$-tetradecane and a biodiesel surrogate. The sulfur-containing liquids tested were two different ultra-low sulfur diesel (ULSD) fuels and a desulfurized version of the military logistic fuel JP-8. Descriptions of the fuels are given below.

\subsection{1. $\quad$-tetradecane (TD)}

With the chemical formula $\mathrm{C}_{14} \mathrm{H}_{30}, n$-tetradecane (TD), has a molecular weight of 198.39 $\mathrm{g} / \mathrm{mol}$ and is a representative surrogate for diesel fuel due to its linear paraffins [51]. A liquid at room temperature, it has a boiling point of $252^{\circ} \mathrm{C}-254^{\circ} \mathrm{C}$ and a liquid density of $0.763 \mathrm{~g} / \mathrm{mL}$. The sample was purchased from Alfa Aesar. 


\subsubsection{Fatty Acid Methyl Ester (FAME) Mixture}

Biodiesel is a diesel fuel alternative that consists of long-chain alkyl esters and is produced from the transesterification of the lipids in vegetable oils or animal fat with an alcohol, typically methanol. These esters are fatty acids and are typically methyl esters. Glycerol is a byproduct of the transesterification process in biodiesel production and must be removed before use in internal combustion engines or fuel reformers. Biodiesel is sulfur-free and is sold commercially in pure form or as a mixture with conventional diesel in concentrations of up to 20\%. Biodiesel has a boiling point range of $315^{\circ} \mathrm{C}-350{ }^{\circ} \mathrm{C}$.

The sample to be used in this work was provided by West Virginia State University (WVSU). The sample was produced from waste vegetable oils obtained from a restaurant close to the WVSU campus. It is a biodiesel-type fuel with the following glycerin analysis shown in Table 3.1 performed by Triton Analytics Corp. in Houston, Texas by the method described in ASTM D-6584:

Table 3.1. Glycerin analysis of FAME mixture.

\begin{tabular}{|c|c|}
\hline Test & Result (wt\%) \\
\hline Free Glycerin & $<0.001$ \\
\hline Total Glycerin & 1.12 \\
\hline Monoglyceride & 0.01 \\
\hline Diglyceride & 0.08 \\
\hline Triglyceride & 1.03 \\
\hline
\end{tabular}


As per ASTM D 6761 and ASTM D 6584, the maximum allowable total glycerin concentration in biodiesel for use in diesel vehicles is 0.050 mass percent. As seen in Table 3.1, the total glycerin of the sample was $1.12 \mathrm{wt} \%$. Although the total glycerin in the biodiesel-type fuel sample exceeds the ASTM standard, the sample represents a fatty acid methyl ester (FAME) mixture typical of a biodiesel-type fuel prepared from waste vegetable oils with minimal processing. Further processing could decrease the total glycerin to a level acceptable for use in on-road diesel vehicles, therefore the FAME mixture could be considered a surrogate for biodiesel fuel.

Compositional analysis was also performed by Triton Analytics Corp. in Houston, Texas by using their trademark nitric oxide ionization spectrometry evaluation technique (NOISE ${ }^{\mathrm{TM}}$ ), where the fuel components are separated by boiling point, bombarded with $\mathrm{NO}^{+}$ions, and then identified by mass spectrometry. The compositional analysis is shown in Table 3.2, where the molecular weight of the sample was determined by breaking it down into its prospective methyl ester components:

Table 3.2. Methyl ester analysis of FAME mixture.

\begin{tabular}{|c|c|c|c|c|c|}
\hline $\begin{array}{c}\text { Fatty Acid } \\
\text { MW }\end{array}$ & $\begin{array}{c}\text { Fatty Acid } \\
\text { Carbon } \\
\text { Number }\end{array}$ & $\begin{array}{c}\text { Fatty Acid } \\
\text { Methyl } \\
\text { Ester MW }\end{array}$ & $\begin{array}{c}\text { Example Methyl } \\
\text { Ester }\end{array}$ & $\begin{array}{c}\text { Relative } \\
\text { Abundance } \\
\text { (wt\%) }\end{array}$ & $\begin{array}{c}\text { Chemical } \\
\text { Formula }\end{array}$ \\
\hline 256 & 16 & 270 & Methyl Palmitate & 10.6 & $\mathrm{C}_{17} \mathrm{H}_{34} \mathrm{O}_{2}$ \\
\hline 278 & 18 & 292 & Methyl Linolenate & 2.2 & $\mathrm{C}_{19} \mathrm{H}_{32} \mathrm{O}_{2}$ \\
\hline 280 & 18 & 294 & Methyl Linoleate & 21.5 & $\mathrm{C}_{19} \mathrm{H}_{34} \mathrm{O}_{2}$ \\
\hline 282 & 18 & 296 & Methyl Oleate & 54.8 & $\mathrm{C}_{19} \mathrm{H}_{36} \mathrm{O}_{2}$ \\
\hline 248 & 18 & 298 & Methyl Stearate & 10.9 & $\mathrm{C}_{19} \mathrm{H}_{38} \mathrm{O}_{2}$ \\
\hline
\end{tabular}


As seen in Table 3.2, the FAME mixture was composed of a large portion of 18-carbon chain fatty acid methyl esters.

\subsubsection{Ultra-Low-Sulfur Diesel (ULSD) Fuels}

Ultra-low-sulfur diesel (ULSD) fuel is petroleum-based and has a maximum allowable sulfur content of 15 parts per-million (ppm). It was proposed by the EPA as the new standard for on-road diesel fuel sold in the U.S. since July 15, 2006 [68]. The sulfur content in ULSD is much lower than the previous U.S. on-road standard for low sulfur diesel of $500 \mathrm{ppm}$. This move to a lower sulfur content not only lowers emissions, but also allows for the use of ULSD in alternative power units. Diesel is a complex mixture with the majority of compounds being saturated paraffins, aromatics, and cycloparaffins [53]. Ultra-low-sulfur diesel fuel has a boiling point range of $180^{\circ} \mathrm{C}-340^{\circ} \mathrm{C}$.

The two different ULSD fuel samples that were used in this work were provided by the NETL in Morgantown, West Virginia. The first sample was obtained from a local gas station in summer 2008 and is designated ULSD 1. The second sample was obtained from a second local gas station in winter 2010 and is designated ULSD 2. Compositional analysis was performed by Triton Analytics Corp. in Houston, Texas by using their trademark nitric oxide ionization spectrometry evaluation technique (NOISE ${ }^{\mathrm{TM}}$ ), where the fuel components are separated by boiling point, bombarded with $\mathrm{NO}^{+}$ions, and then identified by mass spectrometry. The molecular weight of the sample was determined by breaking it down into its hydrocarbon components. 
The compositional analysis of ULSD 1 and ULSD is shown in Table 3.3:

Table 3.3. Hydrocarbon analysis of ULSD 1 and ULSD 2.

\begin{tabular}{|c|c|c|}
\hline & ULSD 1 & ULSD 2 \\
\hline Component & \multicolumn{2}{|c|}{ Relative Abundance (wt\%) } \\
\hline Paraffins & 31.29 & 38.53 \\
\hline Cyclanes & 48.40 & 41.96 \\
\hline Monoaromatics & 13.13 & 15.71 \\
\hline Diaromatics & 6.68 & 3.55 \\
\hline Triaromatics & 0.50 & 0.25 \\
\hline Thiophenic Sulfur & 0.00142 & 0.00116 \\
\hline
\end{tabular}

Upon comparison, the paraffin content of ULSD 1 and ULSD 2 was 31.29 wt\% and $38.53 \mathrm{wt} \%$, respectively. The total aromatic content of ULSD 1 and ULSD 2 was and 20.31 $\mathrm{wt} \%$ and $19.51 \mathrm{wt} \%$, respectively. ULSD 2 has a higher paraffin content and similar aromatic content to ULSD 1 and since paraffins are the most reactive components of diesel fuel, ULSD 2 may be easier to reform. Also, the thiophenic sulfur content of ULSD 2 was 11.6 ppm, whereas the thiophenic sulfur content of ULSD 1 was $14.2 \mathrm{ppm}$. The higher sulfur content of ULSD 1 may cause the reforming catalyst to deactivate faster than ULSD 2 during reforming. 


\subsubsection{Desulfurized JP-8}

Jet propellant-8 (JP-8), also known as NATO F-34, is a widely used U.S. military jet fuel. A petroleum-based aviation turbine fuel, it is described as a kerosene type turbine fuel which contains a corrosion inhibitor/lubricity improver, static dissipater additive, and fuel system icing inhibitor, and may contain metal deactivator and antioxidant [54]. It was specified as a replacement for diesel in U.S. government vehicles in 1990. It has a higher flash point than diesel and is also used in electrical generators, tanks, heaters and stoves [54]. As defined in U.S. Department of Defense detail specification MIL-DTL-83133H, JP-8 has a maximum allowable sulfur content of 3000 ppm. The desulfurized JP-8 used here has a boiling point range of $205^{\circ} \mathrm{C}$ $-300{ }^{\circ} \mathrm{C}$.

The sample for this work was provided by Aerodyne Research, Inc. in Billerica, MA. Aerodyne utilized a proprietary oxidative desulfurization (ODS) process which selectively oxidizes sulfur compounds in the fuel and is followed by adsorption to lower the sulfur content of the JP-8 from 720 ppm to 11.7 ppm [69]. Hydrogen peroxide is used as the oxidant and formic acid is used as a co-oxidant while activated carbon is used as a catalyst and aluminum oxide is used for post-reaction adsorption of oxidized sulfur compounds. The representative ODS chemical reaction is the oxidation of benzothiophene to benzothiophene-sulfone. Compositional analysis was performed by Triton Analytics Corp. in Houston, Texas by using their trademark nitric oxide ionization spectrometry evaluation technique (NOISE ${ }^{\mathrm{TM}}$ ), where the fuel components are separated by boiling point, bombarded with $\mathrm{NO}^{+}$ions, and then identified by mass spectrometry. The molecular weight of the sample was determined by breaking it down into its hydrcarbon components. The NETL provided the following hydrocarbon component analysis of the desulfurized JP-8 shown in Table 3.5: 
Table 3.4. Hydrocarbon analysis of desulfurized JP-8 sample.

\begin{tabular}{|c|c|}
\hline Component & Relative Abundance (wt \%) \\
\hline Paraffins & 45.39 \\
\hline Cyclanes & 41.65 \\
\hline Monoaromatics & 11.94 \\
\hline Diaromatics & 1.03 \\
\hline Triaromatics & 0.00 \\
\hline Thiophenic Sulfur & 0.00117 \\
\hline
\end{tabular}

\subsubsection{Additional Fuel Information and Component Summary}

Physical properties for each fuel from the preceding analyses are listed in Table 3.5 for comparison:

Table 3.5. Physical properties of liquid fuels.

\begin{tabular}{|c|c|c|c|c|c|}
\hline & TD & ULSD 1 & ULSD 2 & $\begin{array}{c}\text { FAME } \\
\text { mixture }\end{array}$ & $\begin{array}{c}\text { Desulfurized } \\
\text { JP-8 }\end{array}$ \\
\hline Property & \multicolumn{5}{|c|}{ Value } \\
\hline MW (g/mol) & 198.39 & 213.19 & 203.01 & 292.94 & 162.95 \\
\hline Density (g/mL) & 0.763 & 0.845 & 0.832 & 0.881 & 0.810 \\
\hline BP $\left({ }^{\circ} \mathrm{C}\right)$ & $252-254$ & \multicolumn{2}{|c|}{$180-340$} & $315-350$ & $205-300$ \\
\hline Average C & 14 & 15.356 & 14.606 & 17.788 & 11.665 \\
\hline Average H & 30 & 28.909 & 27.737 & 35.514 & 22.974 \\
\hline O/C & 0 & 0 & 0 & 0.113 & 0 \\
\hline H/C & 2.143 & 1.883 & 1.899 & 1.997 & 1.970 \\
\hline
\end{tabular}

As seen in Table 3.5, the molecular weight, liquid density, boiling point range, average number of carbon atoms per molecule, average number of hydrogen atoms per molecule, 
molecular oxygen to carbon ratio, and molecular hydrogen to carbon ratio were quite different for each liquid fuel. The physical properties shown in Table 3.5 were used to determine component flowrates such as air flowrate, liquid fuel pump rate, and the vaporization furnace temperature, based upon the given reaction parameters.

A summary of the hydrocarbon analysis for each fuel, with the exception of the FAME mixture (due to its different chemical nature), is shown for comparison in Table 3.6:

Table 3.6. Comparison of hydrocarbon content for selected fuels.

\begin{tabular}{|c|c|c|c|c|}
\hline & TD & ULSD 1 & ULSD 2 & $\begin{array}{c}\text { Desulfurized } \\
\text { JP-8 }\end{array}$ \\
\hline Component & \multicolumn{4}{|c|}{ Relative Abundance (wt\%) } \\
\hline Paraffins & 100 & 31.29 & 38.53 & 45.39 \\
\hline Cyclanes & -- & 48.40 & 41.96 & 41.65 \\
\hline Monoaromatics & -- & 13.13 & 15.71 & 11.94 \\
\hline Diaromatics & -- & 6.68 & 3.55 & 1.03 \\
\hline Triaromatics & -- & 0.50 & 0.25 & 0.00 \\
\hline $\begin{array}{c}\text { Total Aromatics } \\
\text { Thiophenic } \\
\text { Sulfur }\end{array}$ & -- & 20.31 & 19.51 & 12.97 \\
\hline
\end{tabular}

As seen in Table 3.6, the paraffin content of the three sulfur containing fuels varied from $31.29 \mathrm{wt} \%$ to $45.39 \mathrm{wt} \%$, whereas the cyclane content varied from $41.65 \mathrm{wt} \%$ to $48.40 \mathrm{wt} \%$. The total aromatic content of the three sulfur containing fuels varied from $12.97 \mathrm{wt} \%$ to 20.31 wt\%, with JP-8 having the least amount and the two ULSD fuels having similar amounts. The thiophenic sulfur content of the fuels ranged from $11.6 \mathrm{ppm}$ to $14.2 \mathrm{ppm}$. 


\subsection{Experimental Methods}

The commercial MSRI fuel cell that was used during testing had to be reduced slowly while the SOFC furnace reached operating temperature. The Ni in the anode as-received was a $\mathrm{NiO}$ phase and had to be reduced with hydrogen gas to a Ni phase to be active. The reduction procedure takes almost 10 hours, so the first step of the procedure was done overnight. Nitrogen at a flowrate of 100 standard cubic centimeters per minute $(\mathrm{sccm})$ and hydrogen at a flowrate of $5 \mathrm{sccm}$ were sent to the anode while $100 \mathrm{sccm}$ of air was sent to the cathode. The SOFC furnace was programmed on a temperature ramp to go from room temperature to $800{ }^{\circ} \mathrm{C}$ over an eight hour period overnight. The next morning the hydrogen flow was increased to $10 \mathrm{sccm}$ and the nitrogen flow was reduced to $90 \mathrm{sccm}$ such that the total flow to the anode is kept at $100 \mathrm{sccm}$. The 90/10 flow of $\mathrm{N}_{2} / \mathrm{H}_{2}$ was performed for 1 hour. This total anode flowrate was the same as the total cathode flowrate to prevent possible pressure gradients in the cell during reduction. The hydrogen and nitrogen flows were changed over the final hour of reduction such that the flow was $25 \% \mathrm{H}_{2}, 50 \% \mathrm{H}_{2}, 75 \% \mathrm{H}_{2}$, and then $100 \% \mathrm{H}_{2}$ while maintaining a total anode flowrate of $100 \mathrm{sccm}$. Each of these different flow scenarios was performed for a 15 minute period, totaling 1 hour. While operating under $100 \mathrm{sccm}$ of hydrogen to the anode and $300 \mathrm{sccm}$ of air to the cathode, the cell OCV should be $1.10 \mathrm{~V}$, indicating that the cell has been properly reduced and is now ready for current loading.

The cell had two thin voltage-sensing wires that were connected to the cathode and anode current collection meshes. These voltage wires were connected to a computer interface (Omega, Model no. USB-4718 Portable Data Acquisition Module) for data collection. The same computer interface was also used for the data collection of the humidifier temperature, fuel vaporization furnace temperature, reactor temperature, fuel cell temperature, and fuel cell 
current. The cell current was imposed across the cell by means of an electronic load cell (TDI Power, Model no. SDL 1103).

The cell was characterized with electrochemical impedance spectroscopy (EIS) by using an electrochemical interface (Solartron, Model no. S11287) and an impedance/gain-phase analyzer (Slumberger, Model no. S11260) that was connected to a PC for data analysis. For the EIS measurements, the cell current and voltage leads were disconnected from the computer interface used for data collection to avoid mixed signals.

The fuel reforming reactor was operated at $900{ }^{\circ} \mathrm{C}$, as this is the temperature used in the literature and recommended by the researchers at the NETL who supplied the catalyst [50]. The humidifier temperature and liquid fuel flowrate were calculated on an individual fuel basis such that the space velocity through the reactor was approximately 25,000 scc gcatalyst ${ }^{-1} \mathrm{hr}^{-1}$. The fuel vaporization furnace was operated at a temperature above the liquid fuel boiling point, which typically ranges between $375^{\circ} \mathrm{C}$ to $450{ }^{\circ} \mathrm{C}$. The temperature was not allowed to go any higher than $450{ }^{\circ} \mathrm{C}$ to prevent coking in the vaporization lines.

During the start-up procedure of the reforming reactor and fuel vaporization system, the humidifier and the heating tape on the line between the humidifier and the vaporization furnace were heated first. During this heating period, 50 sccm of air was flowed through the humidifier and was sent to the drain to allow the humidifier to come to equilibrium without sending water to the reactor. Once the desired humidifier temperature was reached, the desired air flowrate was set and the humidifier was allowed to reach equilibrium once again. Next, the fuel vaporization furnace and reactor were heated up in small steps over a one-hour period with a 50 sccm nitrogen flow to purge the lines. During this one-hour period, the pump was filled with the desired liquid 
fuel and the fuel line was purged. Once the reactor and fuel vaporization furnace were at operating temperature, the pump was started, introducing the fuel into the vaporization system, and the humidified air stream was also introduced into the system.

The reactor effluent was vented to atmosphere until the system was stable before being introduced to the SOFC anode inlet. The SOFC anode inlet was slowly switched from a 100 sccm hydrogen flow to the reforming reactor effluent under open circuit conditions (no current load). Meanwhile, the SOFC cathode inlet was increased from $100 \mathrm{sccm}$ air to $150 \mathrm{sccm}$ air, to accommodate for the increased anode flow. 


\section{Results and Discussion}

The solid oxide fuel cell system was tested for stand-alone operation on hydrogen before the effluent from the reforming reactor operating on low-sulfur liquid fuels was integrated. The results of these tests are listed below.

\subsection{SOFC Operation with Hydrogen}

Laboratory-grade hydrogen was sent to a mass flow controller and then to the SOFC anode at a flowrate of $100 \mathrm{sccm}$. Dry air from a gas cylinder was sent through a calibrated rotameter to the SOFC cathode at a flowrate of $200 \mathrm{sccm}$. Once the SOFC furnace was at full operating temperature of $800{ }^{\circ} \mathrm{C}$ and stable at an OCV of $1.048 \mathrm{~V}$, a constant current load of 0.25 $\mathrm{A} \mathrm{cm}^{-2}$ was applied for 20 hours, and then a constant current load of $0.50 \mathrm{~A} \mathrm{~cm}^{-2}$ was applied for 50 hours, while the voltage was measured as a function of time, as shown in Figure 4.1:

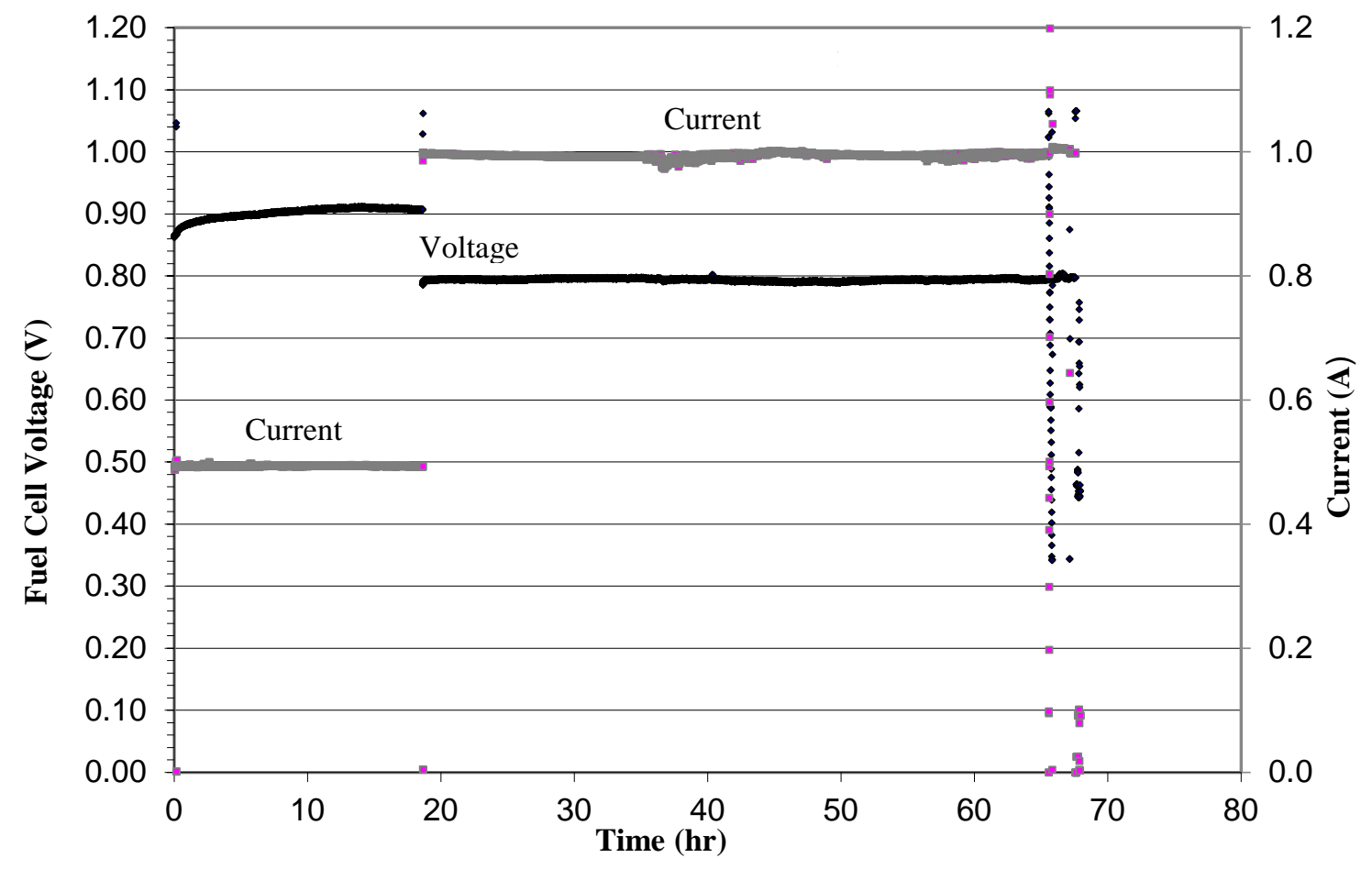

Figure 4.1. SOFC voltage and current at $800{ }^{\circ} \mathrm{C}$ for $100 \mathrm{sccm}$ pure hydrogen. 
As seen in Figure 4.1, the cell voltage increased slightly over the initial 18.3 hour period under a load of 0.50 amps $\left(0.25 \mathrm{~A} \mathrm{~cm}^{-2}\right)$ before the load was removed to allow for $\mathrm{V}$-I-P diagram data to be collected. The slight increase in voltage is associated with the cell conditioning to the SOFC conditions. At 18.6 hours a load of 1.0 amps $\left(0.50 \mathrm{~A} \mathrm{~cm}^{-2}\right)$ was applied and the voltage remained constant for the 50 hour remainder of the test. Notice how the current and hence the voltage vary slightly. This was due to the use of an old analog load cell. After this test, the analog load cell was replaced a newer digital load cell (TDI Power, Model no. SDL 1103). The data collected at 65 hours is plotted in the V-I-P diagram shown in Figure 4.2:

Figure 4.2. V-I-P diagram for 100 sccm pure hydrogen at 65 hours in SOFC at $800{ }^{\circ} \mathrm{C}$.

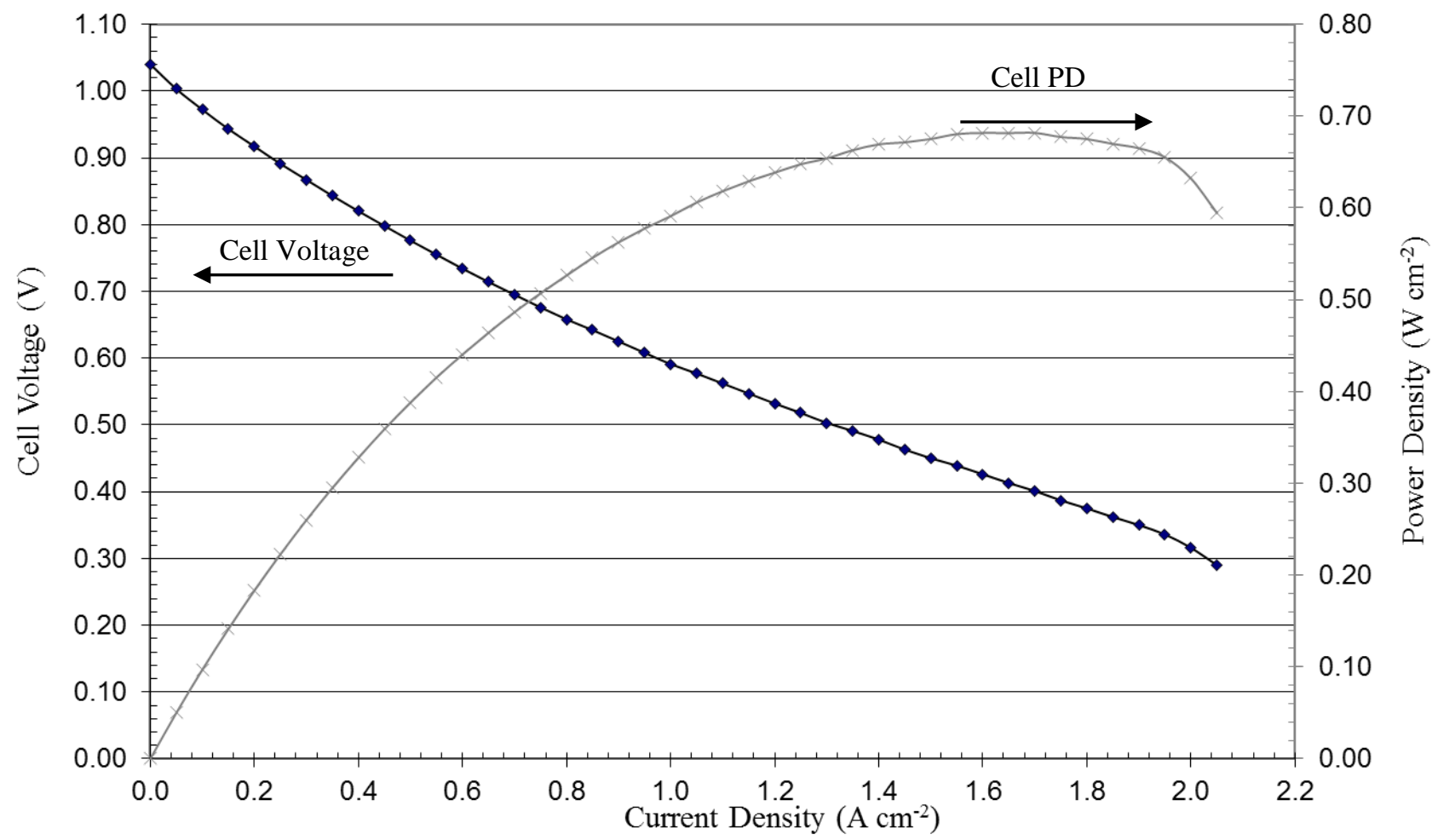

The current imposed across the cell was varied and the voltage was measured accordingly to produce Figure 4.2. The cell voltage as a function of current density is plotted in the dark data 
and its values are represented on the left y-axis. The cell power density as a function of current density is graphed in the gray data and its values are represented on the right y-axis. The cell power density is calculated by multiplying the cell voltage by the imposed current and dividing by the effective cell surface area. Figure 4.2 is representative of a characteristic V-I-P diagram of a SOFC and matches well with the typical performance of the MSRI cell. Therefore, from the positive results shown above, it was concluded that the SOFC system was operating properly. Next, the fuel reforming reactor was tested.

\subsection{Reforming Experiments and Parameters}

The reforming reactor was operated using different liquid fuels under various operating conditions. Five different fuels and two different reforming catalysts were used. The O/C from air and water, GHSV, carrier gas flow, and preheat temperature were varied. A listing of the reforming experiments and parameters including the length of each experiment is shown in Table 4.1: 
Table 4.1. Reforming experiments and parameters.

\begin{tabular}{|c|c|c|c|c|c|c|c|c|c|c|c|c|c|c|c|c|}
\hline & & & & & & & & Feed C & oncentr & ations (1 & 101\%) & & & & & \\
\hline Run & Fuel & Catalyst & $\mathbf{O} / \mathbf{C}_{\mathrm{W}}$ & $\mathrm{O} / \mathrm{C}_{\mathrm{A}}$ & $\mathrm{O} / \mathrm{C}_{\mathrm{F}}$ & $\mathbf{O} / \mathbf{C}_{\text {Total }}$ & gcatalyst & $\mathbf{N}_{2}$ & $\mathbf{O}_{2}$ & $\mathrm{H}_{2} \mathrm{O}$ & Fuel & $\begin{array}{l}\text { Flow } \\
\text { (sccm) }\end{array}$ & $\begin{array}{c}\text { GHSV } \\
\text { (scc/g } / \text { cat } / \mathbf{h})\end{array}$ & $\begin{array}{c}\text { Carrier } \\
\text { (sccm) }\end{array}$ & $\begin{array}{c}\text { Preheat } \\
\left({ }^{\circ} \mathrm{C}\right)\end{array}$ & $\begin{array}{c}\text { Time } \\
\text { (hr) }\end{array}$ \\
\hline 1 & JP-8 & $\mathbf{R h} / \mathrm{Al}_{2} \mathbf{O}_{3}$ & 0.6 & 0.9 & $\mathbf{0}$ & 1.5 & 3.23 & 64.33 & 14.02 & 18.89 & 2.74 & 450 & 41800 & 50 & 375 & 3 \\
\hline 2 & TD & $\mathbf{R h} / \mathrm{Al}_{2} \mathrm{O}_{3}$ & 0.6 & 0.9 & $\mathbf{0}$ & 1.5 & 3.23 & 53.34 & 11.09 & 32.9 & 2.66 & 450 & 41800 & 50 & 375 & 18 \\
\hline 3 & TD & LSRZ & 0.9 & 0.6 & $\mathbf{0}$ & 1.5 & 4.82 & 53.01 & 11.03 & 33.32 & 2.63 & 450 & 28000 & 50 & 375 & 50 \\
\hline 4 & JP-8 & LSRZ & 0.8 & 0.6 & $\mathbf{0}$ & 1.4 & 4.82 & 48.83 & 11.59 & 36.2 & 3.35 & 300 & 18700 & 15 & 375 & 160 \\
\hline & & & & & & & & & & & & & & & & \\
\hline 5 & TD & LSRZ & 0.9 & 0.7 & 0 & 1.6 & 5.41 & 48.87 & 12.22 & 36.41 & 2.49 & 400 & 22200 & 10 & 375 & 23 \\
\hline 6 & ULSD 1 & LSRZ & 0.9 & 0.7 & 0 & 1.6 & 5.41 & 48.86 & 12.13 & 36.74 & 2.26 & 350 & 19400 & 10 & 375 & 23 \\
\hline 7 & ULSD 1 & LSRZ & 0.9 & 0.7 & $\mathbf{0}$ & 1.6 & 5.41 & 51.47 & 12.78 & 33.36 & 2.38 & 350 & 19400 & 10 & 375 & 24 \\
\hline 8 & ULSD 1 & LSRZ & 0.6 & 1.0 & 0 & 1.6 & 5.41 & 63.77 & 16.02 & 18.18 & 2.02 & 350 & 19400 & 10 & 375 & 45 \\
\hline 9 & ULSD 1 & LSRZ & 0.0 & 1.2 & 0 & 1.2 & 5.41 & 78.07 & 19.76 & 0 & 2.14 & 350 & 19400 & 10 & 375 & 11 \\
\hline 10 & ULSD 1 & LSRZ & 0.5 & 1.0 & 0 & 1.5 & 5.41 & 67.65 & 14.88 & 15.5 & 1.95 & 450 & 25000 & 50 & 375 & $6 / 4$ \\
\hline 11 & TD & LSRZ & 0.5 & 1.0 & 0 & 1.5 & 5.41 & 68.04 & 14.61 & 15.24 & 2.09 & 400 & 22200 & 50 & 375 & 28 \\
\hline 12 & ULSD 1 & LSRZ & 0.5 & 1.0 & 0 & 1.5 & 5.41 & 67.53 & 14.86 & 15.65 & 1.94 & 450 & 25000 & 50 & 375 & 10 \\
\hline & & & & & & & & & & & & & & & & \\
\hline 13 & Biodiesel & LSRZ & 0.4 & 1.0 & 0.113 & 1.513 & 4.63 & 70.13 & 15.61 & 12.48 & 1.76 & 450 & 29200 & 50 & 425 & 120 \\
\hline 14 & Biodiesel & LSRZ & 0.4 & 1.0 & 0.113 & 1.513 & 4.63 & 70.27 & 15.65 & 12.3 & 1.76 & 450 & 29200 & 50 & 425 & 100 \\
\hline 15 & ULSD 2 & LSRZ & 0.5 & 1.0 & 0 & 1.5 & 4.63 & 67.76 & 14.9 & 15.28 & 2.04 & 450 & 29200 & 50 & 425 & 12 \\
\hline 16 & ULSD 2 & LSRZ & 0.5 & 1.0 & 0 & 1.5 & 4.63 & 67.82 & 14.92 & 15.21 & 2.04 & 450 & 29200 & 50 & 425 & 48 \\
\hline 17 & ULSD 2 & LSRZ & 0.5 & 1.0 & 0 & 1.5 & 4.63 & 68.15 & 14.99 & 14.79 & 2.05 & 450 & 29200 & 50 & 450 & 26 \\
\hline Lit. & TD & $\mathrm{Rh} / \mathrm{Al}_{2} \mathrm{O}_{3}$ & 0.0 & 1.2 & 0.0 & 1.2 & 0.48 & 80.1 & 17.8 & 0 & 2.1 & 400 & 50000 & & 375 & 5 \\
\hline [50] & $\mathrm{TD}$ & LSRZ & 0.0 & 1.2 & 0.0 & 1.2 & 0.48 & 80.1 & 17.8 & 0 & 2.1 & 400 & 50000 & & 375 & 5 \\
\hline & Biodiesel & $\mathrm{Rh} / \mathrm{Al}_{2} \mathrm{O}_{3}$ & $0-0.5$ & 1.0 & & $1.0-1.5$ & & & & & & 400 & 25000 & & 350 & \\
\hline Lit. & Biodiesel & LSRZ & 0.0 & 1.2 & & 1.2 & & & & & & 400 & 25000 & & 350 & 24 \\
\hline [67] & Biodiesel & $\begin{array}{c}\text { LSRZ } \\
\text { Monolith }\end{array}$ & 0.8 & 0.6 & & 1.4 & & & & & & 400 & 25000 & & 350 & 100 \\
\hline
\end{tabular}


As seen in Table 4.1, a total of 17 experiments were conducted with different fuels, catalysts, and operating conditions. Please note that modifications to the system were made between runs 4 and 5 and also between runs 12 and 13. The quartz sand used in the reactor was switched to quartz chips in between runs 4 and 5 to allow more void space for possible carbon deposits. Capillary tubing with a 1/16” OD and an internal diameter of 0.020 ” was installed between the pump and the purge valve to ensure pump operation above 300 psig (2.17 MPa), which is required of a HPLC pump, between runs 12 and 13. Only the experiments listed in bold type will be discussed in detail in the following sections, as they provided relevant information, whereas the experiments listed in plain font will be briefly discussed. The experiments listed at the bottom of Table 4.1 are from the literature and are used as a reference. The experiments on n-tetradecane were performed by Haynes, et al. [50]. The experiments on biodiesel were performed by Siefert, et al. [67]. It should be noted that the listings for gcatalyst are for total catalyst; the LSRZ catalyst was 20\% active phase (used for calculation of GHSV). The LSRZ had a $20 \%$ active phase due to structural defects and substitution limitations that occurred during the preparation process.

The following discussion of experiments and results will be grouped by fuel utilized and will conclude with a comparison of the operating conditions and findings. 


\subsection{Initial Trial Operation of SOFC on Reformed Desulfurized JP-8}

The first liquid hydrocarbon tested was a desulfurized version of the military logistic fuel JP-8. It was chosen simply as a trial, as it was the only low-sulfur liquid fuel available at the time of experimentation. This run (Run 1 Table 4.1) was a check on the operation of the reformer and the pump. JP-8 at a flowrate of $0.110 \mathrm{~mL} / \mathrm{min}$ was injected into the reforming reactor with nitrogen and humidified air at a total flowrate of $450 \mathrm{sccm}$. The reformed mixture was then sent to the anode of the fuel cell. The catalyst utilized in the experiment (described in Chapter 3) was a commercially available $0.5 \mathrm{wt} \%$ rhodium on alumina $\left(\mathrm{Rh} / \gamma-\mathrm{Al}_{2} \mathrm{O}_{3}\right)$. Data collected from the beginning of the test are shown in Figure 4.3 and Figure 4.4:

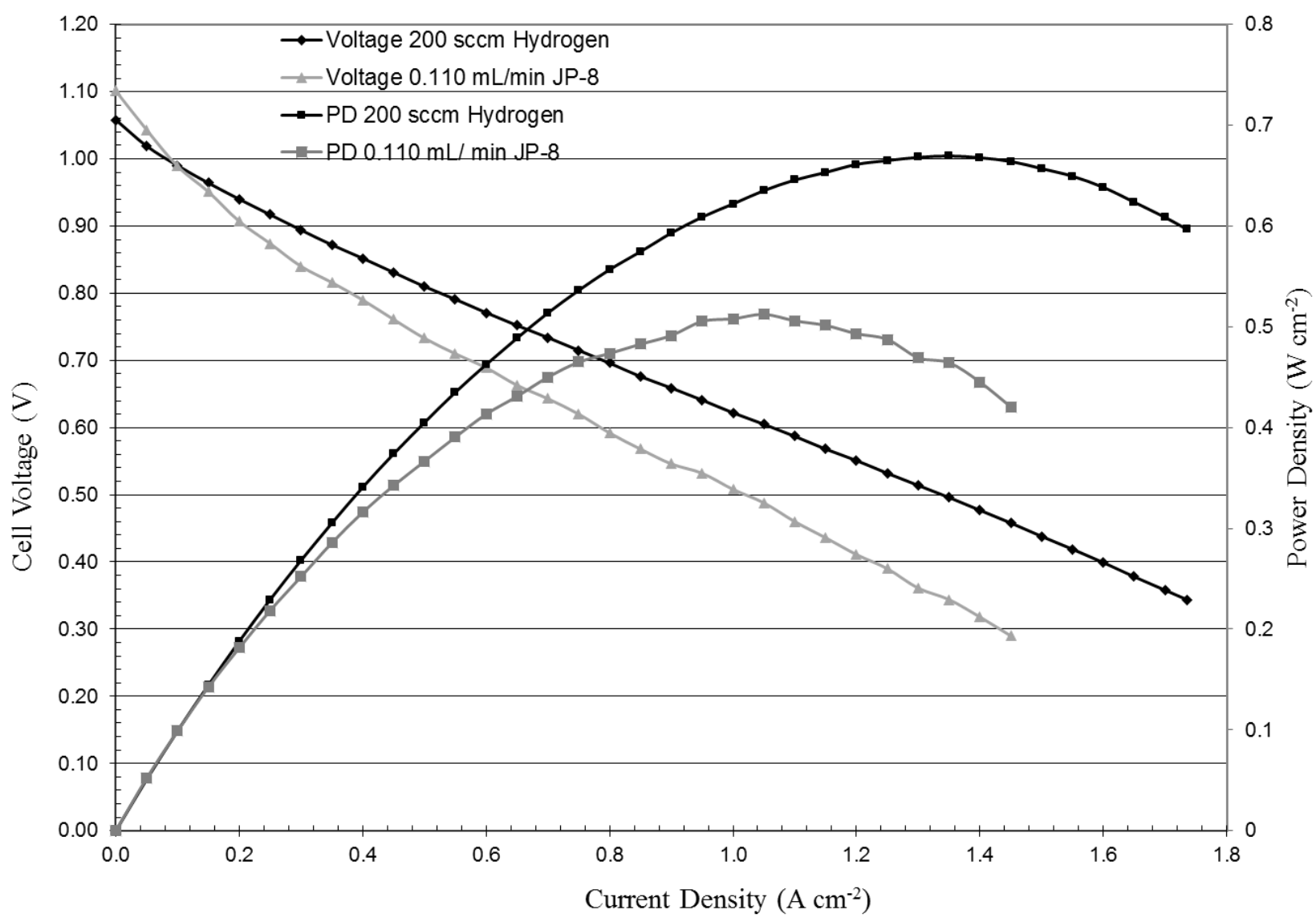

Figure 4.3. V-I-P diagram for $200 \mathrm{sccm}$ pure $\mathrm{H}_{2}$ and $0.110 \mathrm{~mL} / \mathrm{min} \mathrm{JP}-8$ in SOFC at $800{ }^{\circ} \mathrm{C}$. 
As shown in Figure 4.3, the initial run of JP-8 at a flowrate of $0.110 \mathrm{~mL} / \mathrm{min}$ could not produce power densities as high as those produced by pure hydrogen at a flowrate of $200 \mathrm{sccm}$. This is due to the lower concentration of hydrogen in the reformate, because of the presence of other gas species, primarily carbon monoxide and nitrogen. The cell impedance spectra under the conditions of 200 sccm hydrogen and $0.110 \mathrm{~mL} / \mathrm{min}$ JP-8 are shown in Figure 4.4:

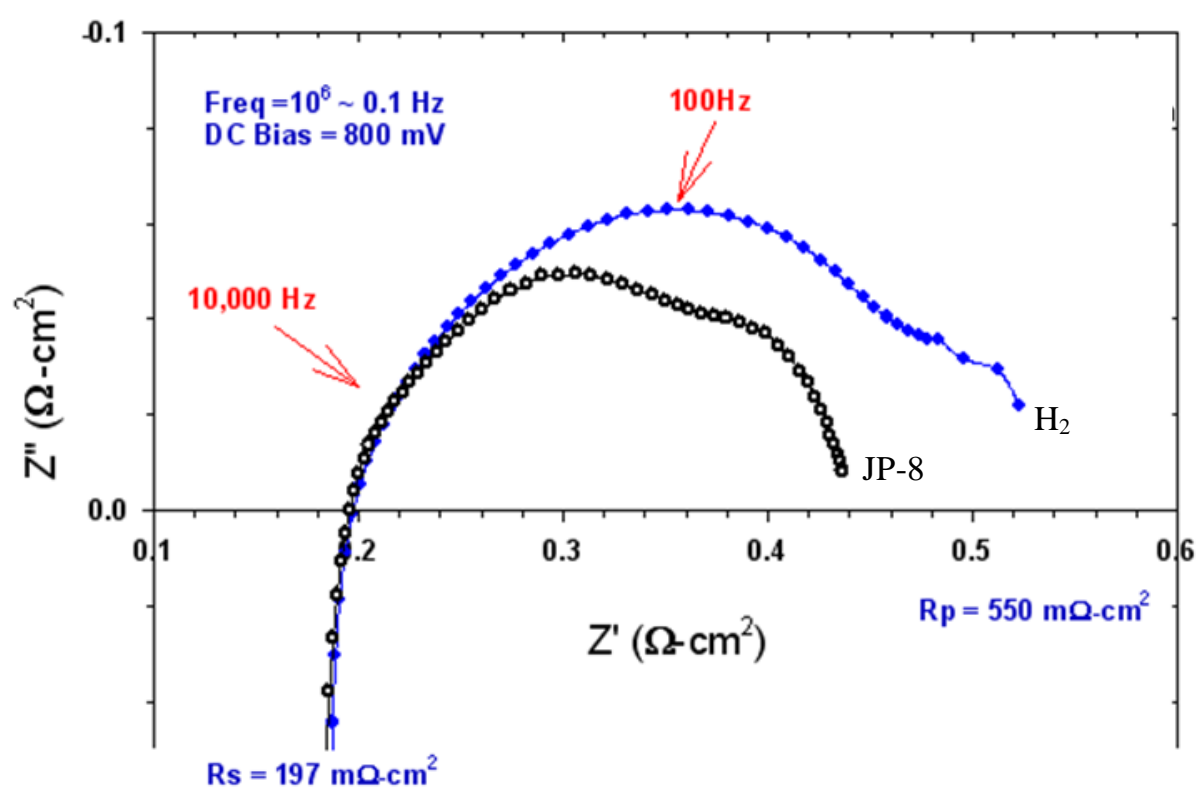

Figure 4.4. Cell impedance spectra comparing $200 \mathrm{sccm} \mathrm{H}_{2}$ in black opened dots and $0.110 \mathrm{ml} / \mathrm{min} \mathrm{JP}-8$ fuel in blue solid dots under a DC bias of $800 \mathrm{mV}$.

As shown by the cell impedance spectra in Figure 4.4, the ohmic resistance of the cell was the same under the SOFC operating conditions with the different fuels. However, the polarization resistance was greater in the case of JP-8 reformation, due to lower rates of hydrogen gas diffusion resulting from the lower concentration of hydrogen in the reformate. 
The initial test of reformed JP-8 being sent to the anode of the SOFC was only performed for a total time of 3 hours and a short segment of the cell voltage as a function of time under a current load of $0.50 \mathrm{~A} \mathrm{~cm}^{-2}$ is shown in Figure 4.5:

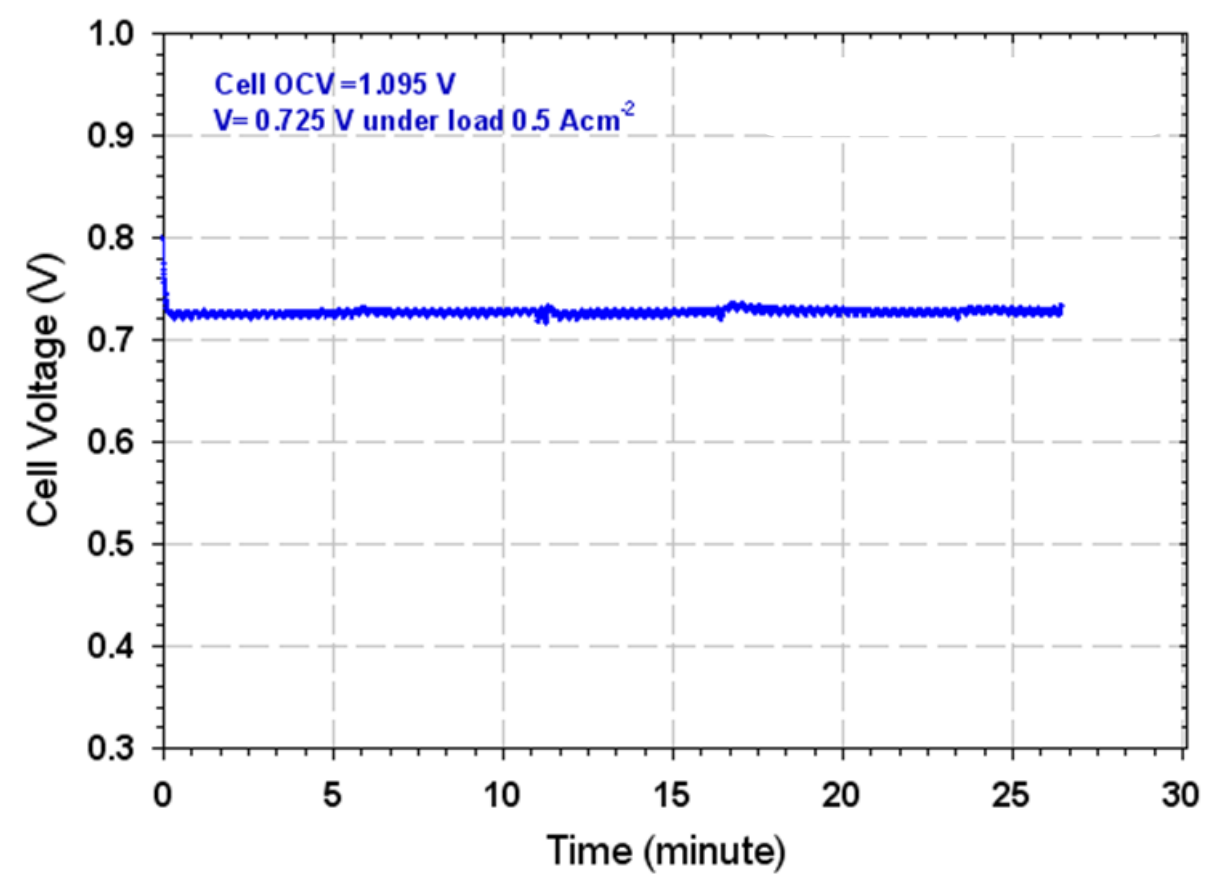

Figure 4.5. SOFC voltage at $800^{\circ} \mathrm{C}$ for $0.110 \mathrm{~mL} / \mathrm{min}$ reformed $\mathrm{JP}-8$ using $\mathrm{Rh} / \gamma-\mathrm{Al}_{2} \mathrm{O}_{3}$ catalyst. 
Although the cell voltage appears relatively stable during this short run under a current load of $0.50 \mathrm{~A} \mathrm{~cm}^{-2}$, upon closer inspection it was revealed that there were small oscillations in the cell voltage, as shown in Figure 4.6:

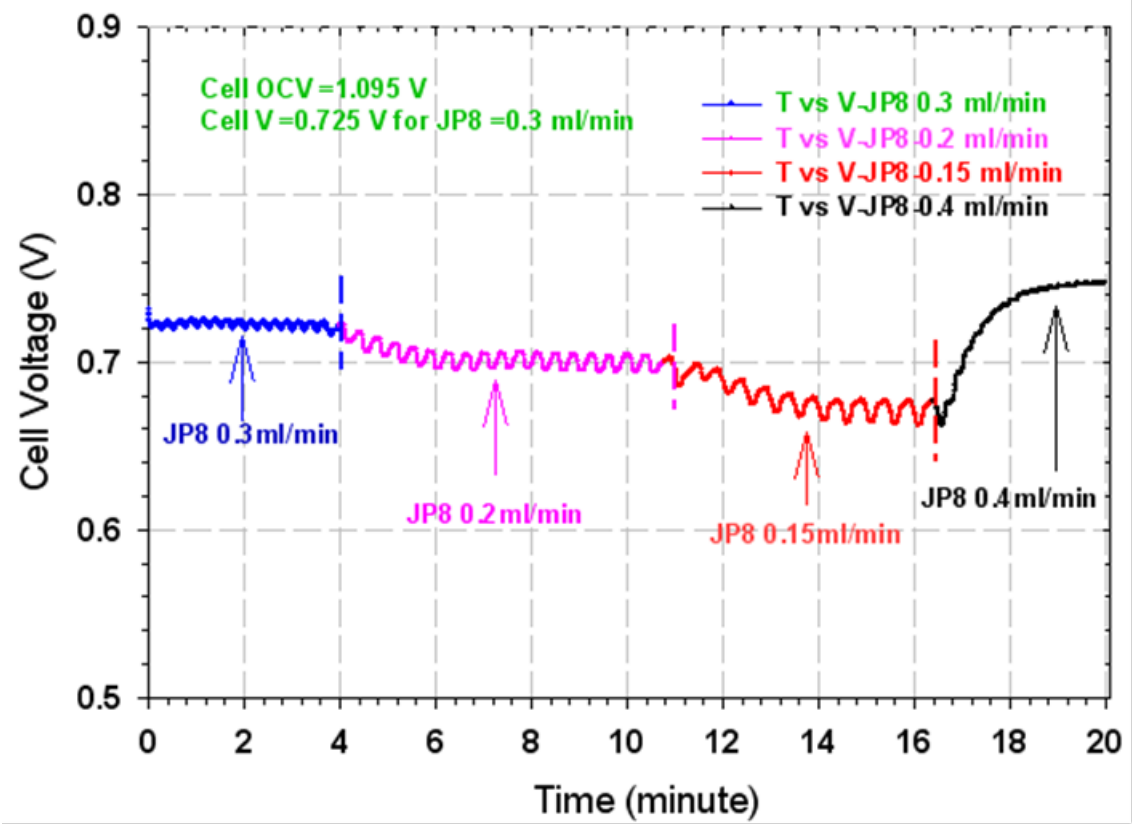

Figure 4.6. SOFC voltage at $800^{\circ} \mathrm{C}$ as a function of time for different $\mathrm{JP}-8$ flowrates.

As shown in Figure 4.6, the cell voltage oscillated under the different JP-8 flowrates of 0.30, 0.20, 0.15, and $0.40 \mathrm{~mL} / \mathrm{min}$. The oscillation periods are 15, 24, 36, and 11 seconds, respectively. This occurrence was believed to be due to an inconsistent flow from the liquid fuel pump. Due to the inconsistent pumping and therefore cell voltage, the test was stopped after a short 3 hour period. The SOFC was removed from the test stand after the test and a picture of the cell anode is shown in Figure 4.7: 


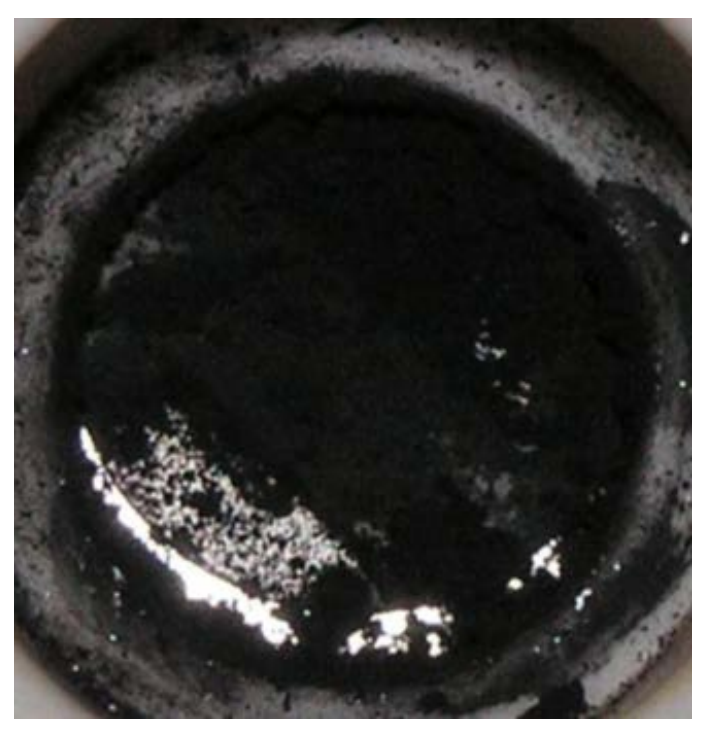

Figure 4.7. SOFC anode after 3 hour $\mathrm{JP}-8$ run on commercial $0.5 \mathrm{wt} \% \mathrm{Rh} / \gamma-\mathrm{Al}_{2} \mathrm{O}_{3}$ catalyst.

As shown in Figure 4.7, there was an extensive amount of coking found of the cell after the short experiment. It was determined after this experiment that the pump needed to be thoroughly purged to remove any possible air bubbles for future experiments and also should be operated at higher pressures for proper operation.

\subsection{SOFC Operation on Reformed $n$-tetradecane}

Due to the complex nature of JP-8 and the limited available sample supply, it was decided to experiment with a simpler liquid fuel following the JP-8 tests to further substantiate the proper operation of the fuel reformer. The liquid hydrocarbon $n$-tetradecane (TD) was selected as a model compound for the linear paraffins contained in a typical diesel fuel. Paraffins compose the largest portion of logistics fuels (approximately $40 \mathrm{wt} \%$ ) and are also the most reactive compounds [52]. Therefore, $n$-tetradecane was tested in the reformer/SOFC 
system as a diesel surrogate. Nitrogen, humidified air, and vaporized TD were injected into the reactor at a total gas flow rate of $450 \mathrm{sccm}$ and converted into syngas in the reforming reactor using the commercial $\mathrm{Rh} / \gamma-\mathrm{Al}_{2} \mathrm{O}_{3}$ catalyst (Run 2 Table 4.1). The reaction products were then fed to the anode of the fuel cell. The OCV of the cell was $1.020 \mathrm{~V}$. This was a short test to check the operation of the system at a much lower total flowrate than the previous JP-8 test with an improved pump pressure obtained by thorough purging of the pump. Table 4.2 lists the feed flows to the reactor. The relative humidity of the air stream was 38.65\% and the flowrate of TD was $0.136 \mathrm{~mL} / \mathrm{min}$.

Table 4.2. Flows for $n$-tetradecane run.

\begin{tabular}{|c|c|c|c|}
\hline $\mathrm{O} / \mathrm{C}$ & 1.500 & & \\
\hline $\mathrm{O} / \mathrm{C}$ from air & 0.600 & & \\
\hline $\mathrm{O} / \mathrm{C}$ from $\mathrm{H} 2 \mathrm{O}$ & 0.900 & & \\
\hline Air & 238.10 & $\mathrm{sccm}$ & \\
\hline Water & 150.00 & $\mathrm{sccm}$ & $38.65 \%$ humidity \\
\hline Nitrogen & 50.00 & $\mathrm{sccm}$ & \\
\hline Fuel & 11.90 & $\mathrm{sccm}$ & \\
\hline Fuel flow & 0.136 & $\mathrm{ml} / \mathrm{min}$ & \\
\hline
\end{tabular}


The test results are shown below in Figure 4.8 and Figure 4.9. Figure 4.8 shows the voltage as a function of time under a current load of $0.50 \mathrm{~A} \mathrm{~cm}^{-2}$. As shown in Figure 4.8, the cell voltage was stable for the duration of the test, proving that the reformer and the pump were operating correctly using the commercial $\mathrm{Rh} / \gamma-\mathrm{Al}_{2} \mathrm{O}_{3}$ catalyst.

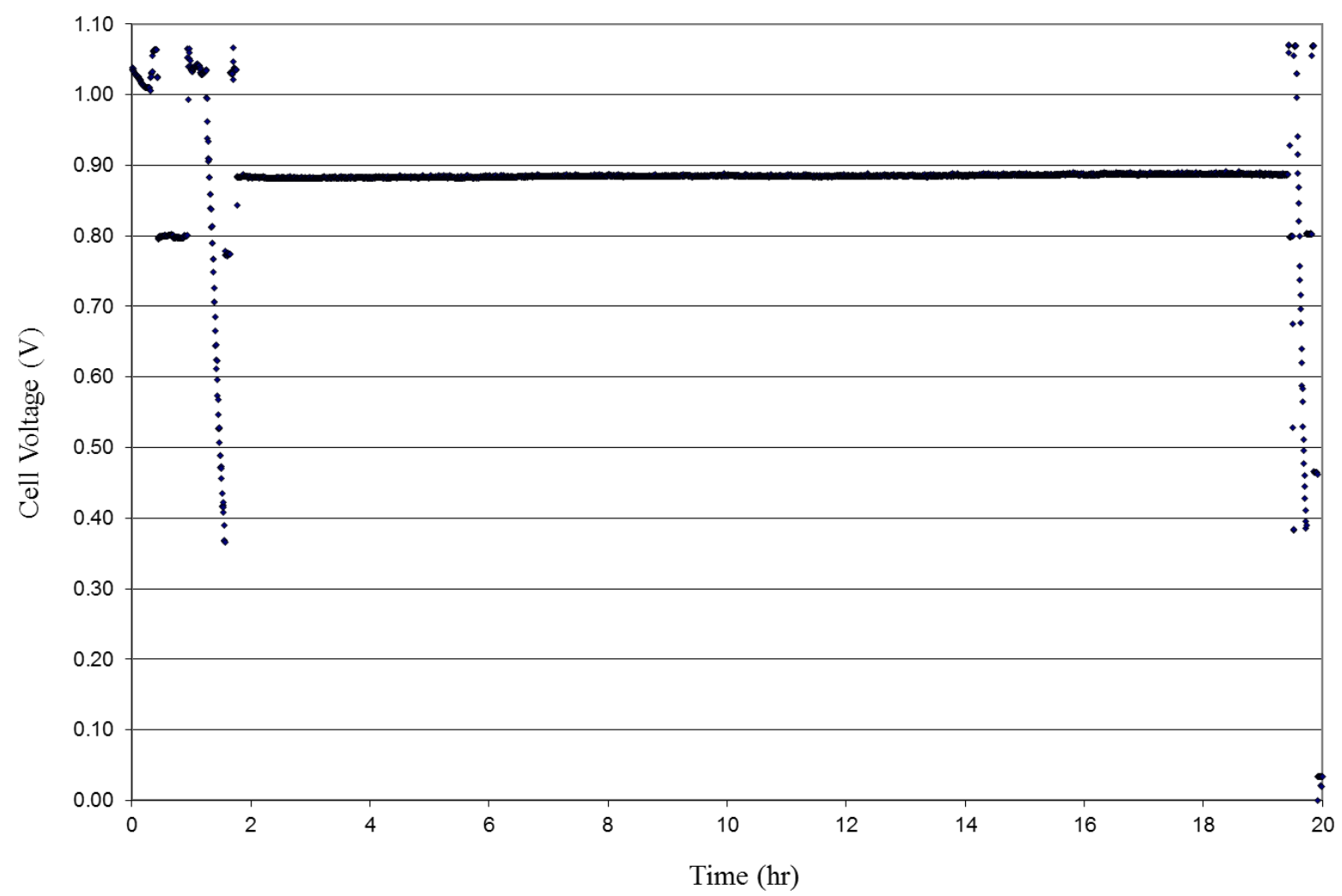

Figure 4.8. SOFC voltage at $800^{\circ} \mathrm{C}$ under a current load of $0.50 \mathrm{~A} \mathrm{~cm}^{-2}$ for $0.136 \mathrm{~mL} / \mathrm{min}$ reformed $n$-tetradecane using $\mathrm{Rh} / \gamma-\mathrm{Al}_{2} \mathrm{O}_{3}$ catalyst in the reformer.

Figure 4.9 shows two V-I curves and two power density curves: $0.136 \mathrm{~mL} / \mathrm{min} n$ tetradecane and 200 sccm pure hydrogen as a reference. As shown in Figure 4.9, the cell voltage and power density for the TD run were comparable to those of the 200 sccm pure hydrogen. 


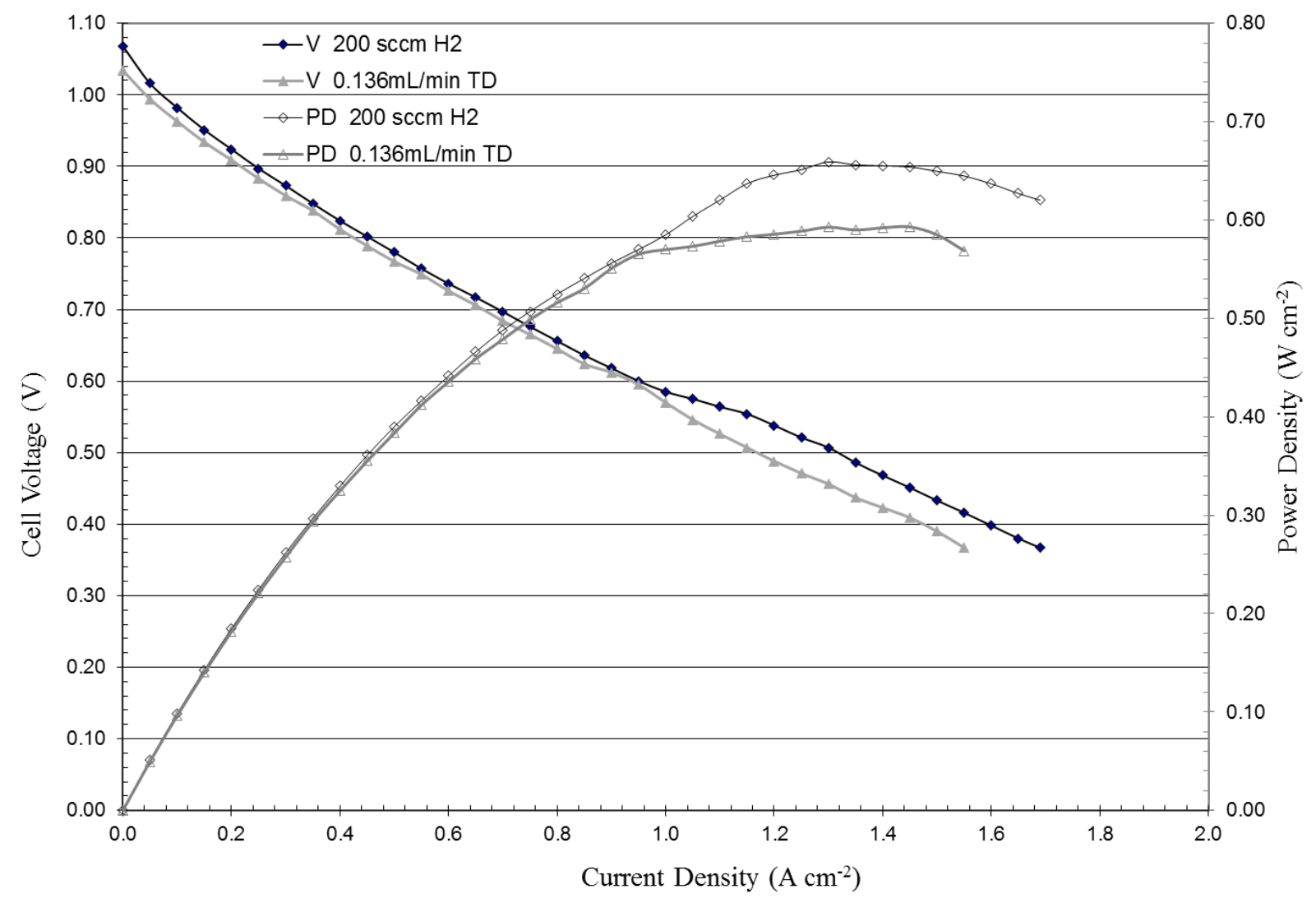

Figure 4.9. Comparison of SOFC performance at $800^{\circ} \mathrm{C}$ with $200 \mathrm{sccm}$ pure hydrogen and reformed $n$ tetradecane using commercial $\mathrm{Rh} / \gamma-\mathrm{Al}_{2} \mathrm{O}_{3}$ catalyst in the reformer.

Given the favorable results shown in Figures 4.8 and 4.9, it was determined that both the reforming reactor and HPLC pump were operating properly and were ready for future experiments.

For the remainder of experiments, the NETL LSRZ catalyst (as described in Chapter 3) was used in the fuel reforming reactor. Also, a thin layer of the LSRZ catalyst was applied to the anode of the MSRI button cell used in the SOFC with a nickel-based paste. This was done to help mitigate carbon deposition on the anode by gaseous hydrocarbons that were not converted 
to hydrogen and carbon monoxide in the reforming reactor, as there was no gas conditioning done between the reformer outlet and SOFC anode inlet.

The first experiment conducted with the LSRZ catalyst in the reforming reactor and applied to the cell anode was performed using $n$-tetradecane as the liquid fuel (Run 3 Table 4.1). Hydrogen at a flowrate of $200 \mathrm{sccm}$ was sent to the SOFC for a 20 hour period before the reformed $n$-tetradecane was sent to the SOFC anode for a 50 hour period at flowrate of 0.136 $\mathrm{mL} / \mathrm{min}$. The SOFC voltage at $800^{\circ} \mathrm{C}$ under a current load of $0.50 \mathrm{~A} \mathrm{~cm}^{-2}$ as a function of time is shown in Figure 4.10:

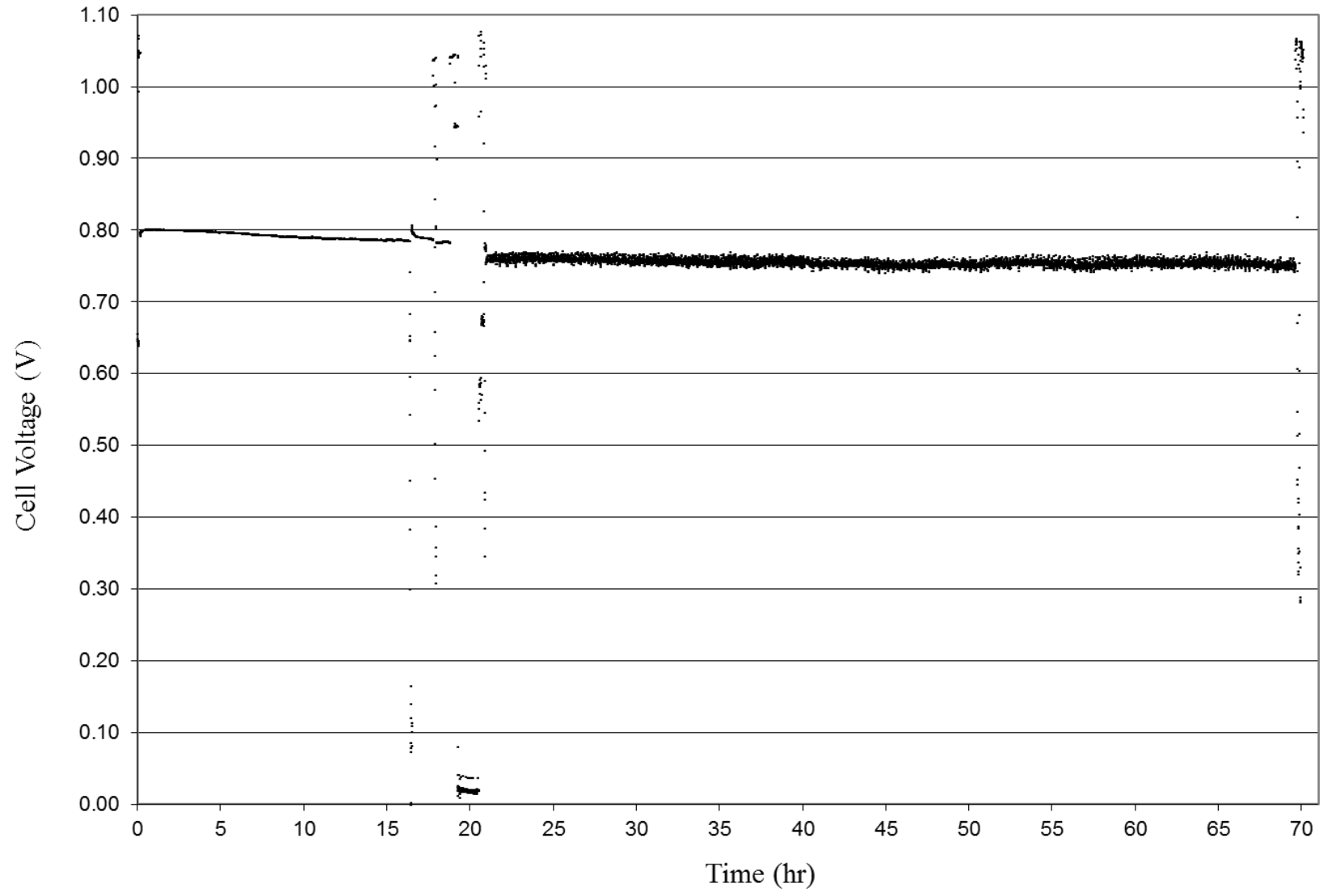

Figure 4.10. SOFC voltage at $800^{\circ} \mathrm{C}$ under a current load of $0.50 \mathrm{~A} \mathrm{~cm}^{-2}$ for 200 sccm hydrogen and 0.136 $\mathrm{mL} / \mathrm{min}$ reformed $\mathrm{n}$-tetradecane using LSRZ catalyst in the reformer and on the SOFC anode. 
As seen in Figure 4.10, the cell voltage was stable during the 50 hour period under reformed $n$-tetradecane while using the LSRZ catalyst in the reforming reactor and also on the SOFC anode. Data for a V-I-P diagram was taken at 20 hours and the results are shown in Figure 4.11:

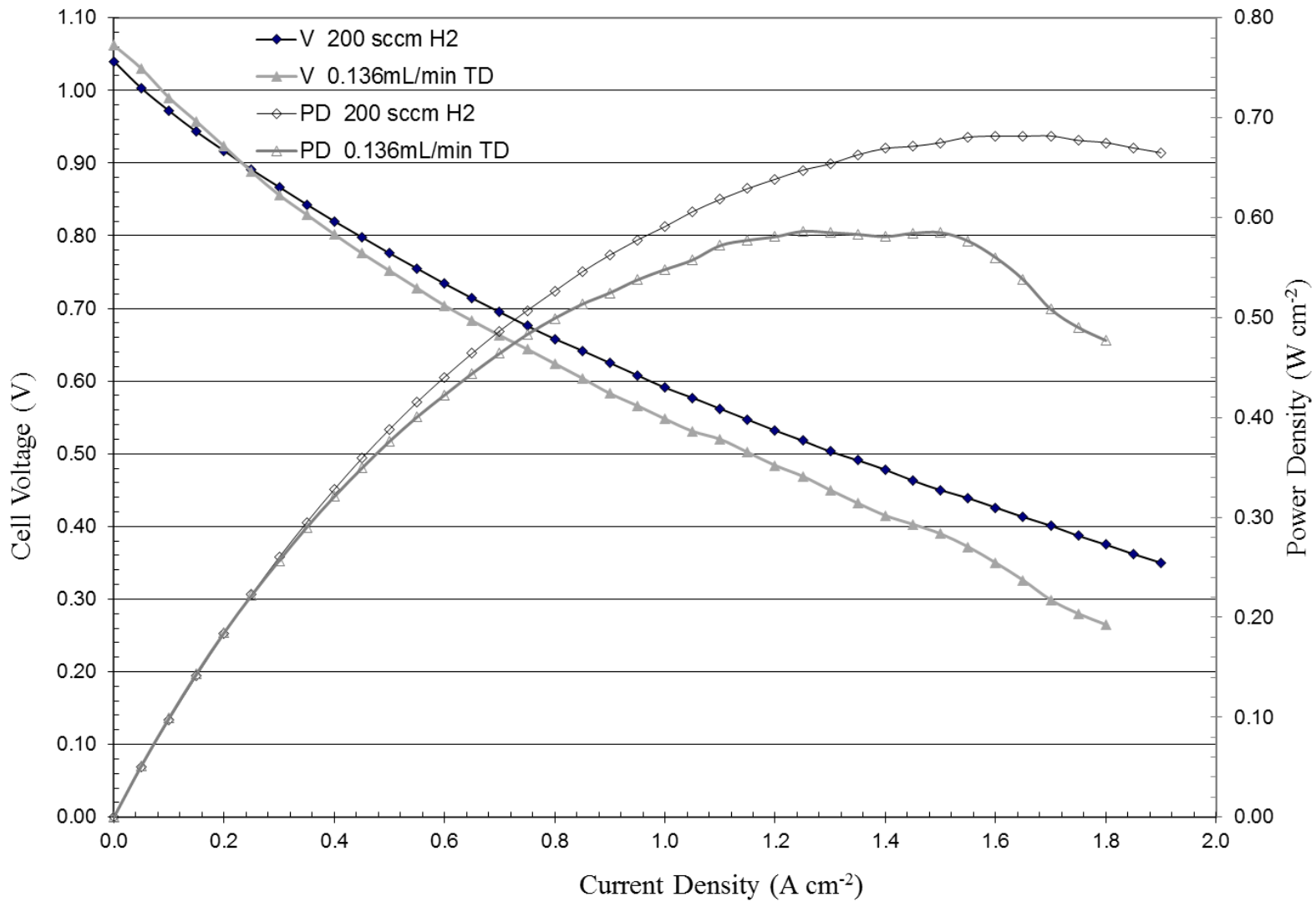

Figure 4.11. Comparison of SOFC performance at $800^{\circ} \mathrm{C}$ with $200 \mathrm{sccm}$ pure hydrogen and reformed $n$ tetradecane using NETL LSRZ catalyst in the reformer and on the SOFC anode.

As seen in Figure 4.11, the SOFC performed well under both operating conditions, with the 200 sccm of pure hydrogen producing higher power densities. This was expected, due to the lower concentration of hydrogen in the $n$-tetradecane reformate. The results shown in Figure 4.11 are very similar to the results shown in Figure 4.9, proving that the LSRZ catalyst in the reformer was working and that the addition of the LSRZ catalyst to the SOFC anode had little 
effect on the ability to produce high power densities while helping to mitigate carbon deposition on the anode. No carbon was observed on the SOFC anode after operation. It was then determined from these favorable results to continue using the NETL LSRZ catalyst in the reforming reactor and also on the SOFC anode for future experiments.

\subsection{SOFC Operation on Reformed Desulfurized JP-8}

The next liquid fuel tested in the reformer/SOFC system was a desulfurized version of the military logistic fuel JP-8. The desulfurized JP-8 was sent to the reforming reactor at a flowrate of $0.094 \mathrm{~mL} / \mathrm{min}$ using the NETL LSRZ catalyst in the fuel reforming reactor with an $\mathrm{O} / \mathrm{C}$ of 0.60 and 0.80 from air and water, respectively (Run 4 Table 4.1). First, hydrogen at a flowrate of 100 sccm was sent to the SOFC anode for a short time during startup. The JP-8 reformate at a total flowrate of 300 sccm was then sent to the SOFC anode, which had a thin layer of the LSRZ catalyst applied, without any sample conditioning done between the reformer outlet and the SOFC anode inlet. The SOFC voltage as a function of time under a current load of $0.50 \mathrm{~A} \mathrm{~cm}^{-2}$ is shown in Figure 4.12: 


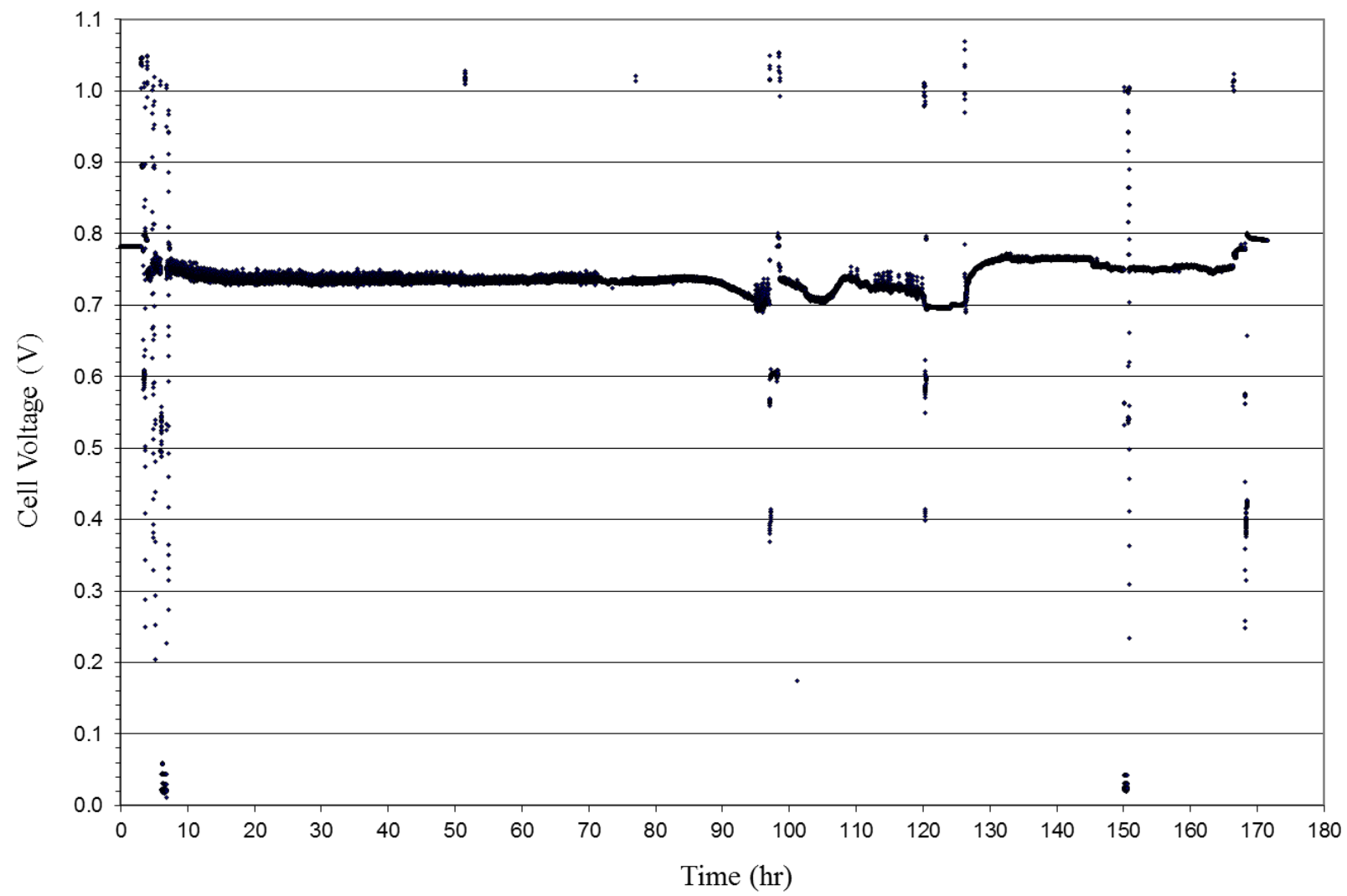

Figure 4.12. SOFC voltage at $800^{\circ} \mathrm{C}$ under a current load of $0.50 \mathrm{~A} \mathrm{~cm}^{-2}$ for $0.094 \mathrm{~mL} / \mathrm{min}$ reformed desulfurized JP-8 using LSRZ catalyst in the reformer and on the SOFC anode.

As seen in Figure 4.12, the SOFC voltage was relatively stable during the first 88 hours of operation under reformed desulfurized JP-8, but at 89 hours the cell voltage began to decrease. The total time of operation under desulfurized JP-8 without any intervening other than data and sample collection for VI curves and GC analysis was 93 hours. The reformer pressure increased throughout the entire run, starting at 20.4 psia and rose to 39.5 psia at 93 hours. This affected the amount of water being sent to the reactor and thus the $\mathrm{O} / \mathrm{C}$ from water, meaning that the temperature of the humidifier had to be increased accordingly, as discussed below. At 93 hours, 
the SOFC was switched to hydrogen while the JP-8 flow to the reactor was stopped, allowing humidified air to oxidize any coking in the reactor. This reduced the pressure of the system.

The increase of pressure in the reactor was of major concern because of the use of a heated humidifier in the system. As the pressure in the reactor increased, so did the pressure of the air in the humidifier. This changed the water/air equilibrium in the humidifier and thus decreased the amount of water being sent to the reactor at the set temperature. To maintain the $\mathrm{O} / \mathrm{C}$ ratio from water being sent to the reactor from the humidified air stream, the humidifier temperature had to be increased accordingly as the pressure in the reactor increased. This was found to be problematic during operation when pressure increases in the reactor occurred. The temperature of the humidifier was adjusted as often as necessary until the humidifier heating system reached near-100\% operation.

During the reactor burnout at 95 hours, the temperature of the humidifier was adjusted and allowed to equilibrate. Then the JP-8 flow was returned to the vaporization system and reactor and then the SOFC. The cell voltage after this point was erratic and necessitated a more thorough carbon oxidation in the reforming reactor. At 120 hours, the SOFC was switched to 50 sccm hydrogen while humidified air was sent to the reactor for a total time of 5 hours. At 125 hours, the JP-8 was sent to the reforming reactor and then the SOFC. The voltage seemed stable for almost 20 hours but then the pressure increased in the system and once again caused erratic operation for the remainder of the test. 
Cell impedance spectra were taken at 2 hours and 140 hours. The results are shown in Figure 4.13:

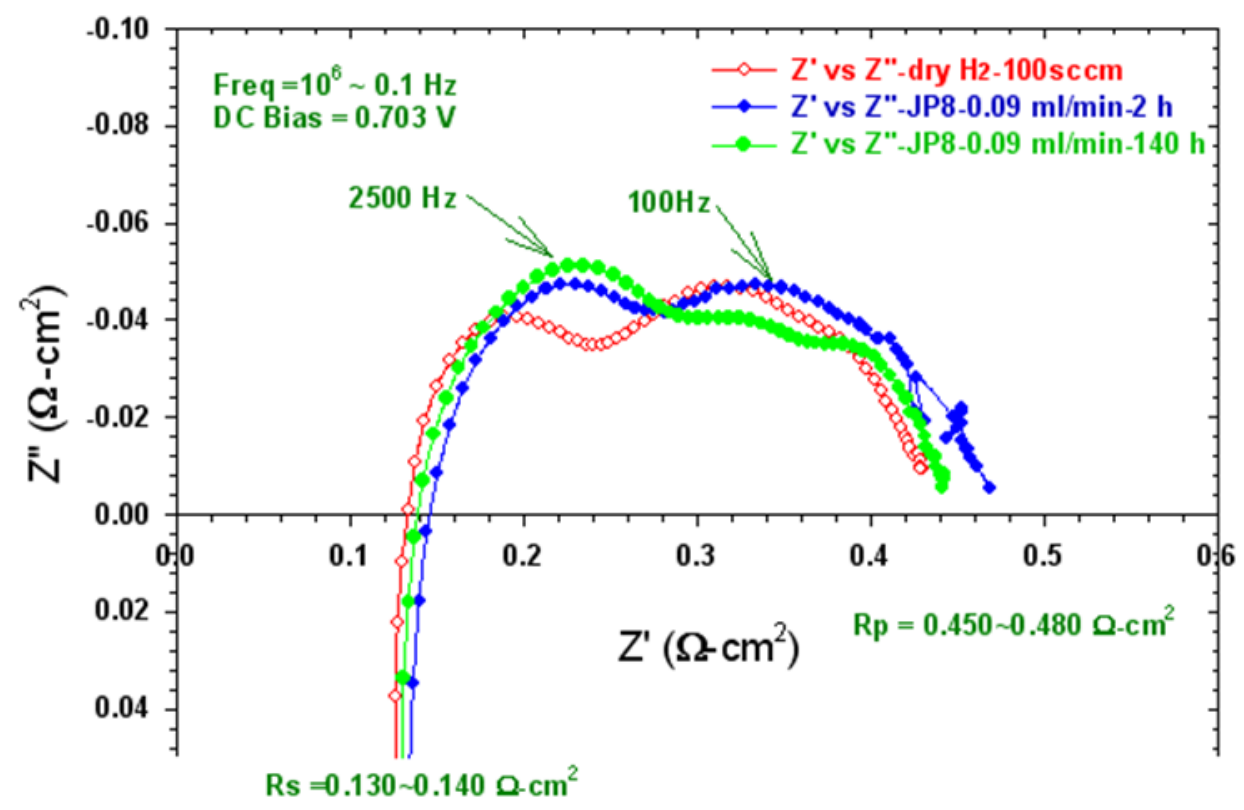

Figure 4.13. Cell impedance spectra under a DC bias of $0.703 \mathrm{~V}$ for $100 \mathrm{sccm}$ pure hydrogen in red open dots and $0.094 \mathrm{~mL} / \mathrm{min} \mathrm{JP-8}$ fuel at 2-hr and 140-hr in blue and green closed dots, respectively.

As seen in Figure 4.13, the results of the cell impedance spectra at 2 hours and 140 hours are very similar, indicating that the ohmic and polarization resistances of the cell changed only slightly during the 138 hour period between data collection. Thus, the performance of the SOFC did not deteriorate during the run. Data for V-I-P diagrams were also collected at 2 hours and 140 hours and the results are shown in Figure 4.14: 


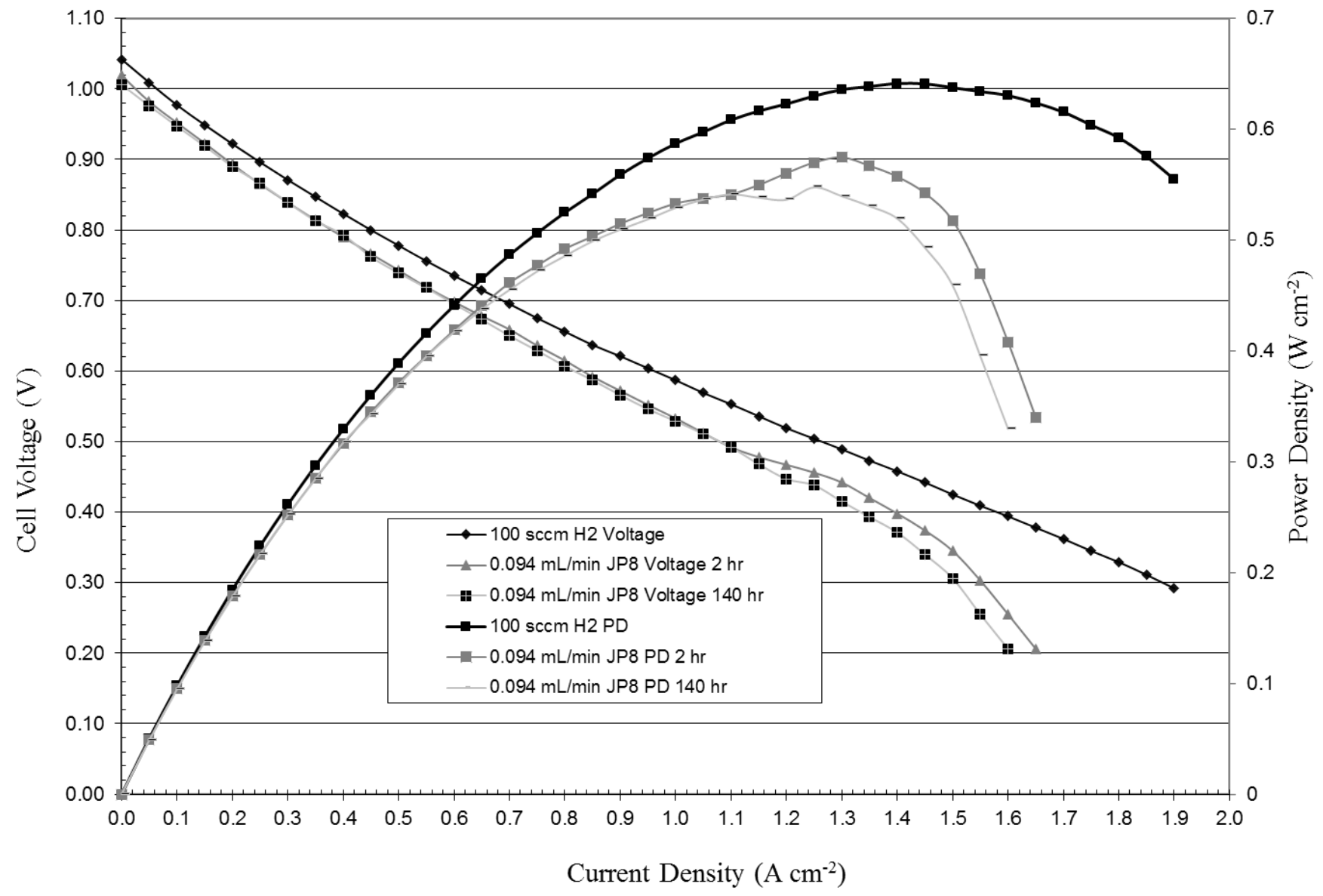

Figure 4.14. Comparison of SOFC performance at $800^{\circ} \mathrm{C}$ with $100 \mathrm{sccm}$ pure hydrogen and reformed desulfurized JP-8 using NETL LSRZ catalyst in the reformer and on the SOFC anode.

As seen in Figure 4.14, the power densities of the desulfurized JP-8 were similar for the data collected at 2 hours and 140 hours, however, higher power densities were achieved earlier in the run. All the data up to 120 hours were with the sample labeled "7 ppm sulfur” JP-8 fuel supplied by Aerodyne Research, Inc. At this point the 7 ppm sulfur fuel was nearly gone, so two volumes of JP-8 with approximately 9 ppm sulfur were added in the fuel tank and mixed with the remaining one volume of approximately 7 ppm sulfur JP-8. When the mixed JP-8 fuel was fed to the cell again, the cell showed slightly better performance than before. This suggests that the energy densities or chemical composition of these two JP-8 fuels were slightly different. The 
fuel data given in Chapter 3 for JP-8 was an analysis of the sample labeled "9 ppm sulfur" as received from Aerodyne Research, Inc. The analysis showed a thiophenic sulfur content of 11.7 ppm. The sample labeled "7 ppm sulfur” was not analyzed.

The cell was shut down after the JP-8 fuel was exhausted. It was believed that the reforming catalyst was still functioning properly, but the coking was caused by a low O/C ratio in the feed and/or clogging in the fuel line. Most likely, the air was not completely saturated with water vapor, thus lowering the oxygen input. Also, coke formation was observed in the liquid fuel inlet line going into the reactor, indicating possible pyrolysis of the vaporized fuel before entering the reforming reactor. Unfortunately, the JP-8 fuel supply was expended and another run at different operating conditions could not be tested.

Two gas samples of the reformed desulfurized JP-8 were collected from the reforming reactor outlet at times 12 minutes apart after operation for 52 hours. The results of the gas chromatograph analysis are shown in Table 4.3: 
Table 4.3. Gas chromatograph analysis of reformed desulfurized JP-8.

\begin{tabular}{|l|l|r|r|r|r|r|}
\hline Time & & 1048 & 1100 & & \\
\hline & & & & & \multicolumn{1}{l|}{ average } & std. dev. \\
\hline $\mathrm{H}_{2}$ & $\%$ & 36.45 & 35.91 & 36.18 & 0.380 \\
\hline $\mathrm{CO}_{2}$ & $\%$ & 0.719 & 0.303 & 0.511 & 0.294 \\
\hline $\mathrm{O}_{2}$ & $\%$ & 0.522 & 0.525 & 0.524 & 0.002 \\
\hline $\mathrm{N}_{2}$ & $\%$ & 40.41 & 40.87 & 40.64 & 0.326 \\
\hline $\mathrm{CO}$ & $\%$ & 20.95 & 21.42 & 21.18 & 0.330 \\
\hline & & & & & \\
\hline $\mathrm{CH}_{4}$ & $\mathrm{ppm}$ & 4477 & 3961 & 4219 & 364 \\
\hline $\mathrm{C}_{2} \mathrm{H}_{6}$ & $\mathrm{ppm}$ & 577 & 392 & 484 & 130 \\
\hline $\mathrm{C}_{2} \mathrm{H}_{4}$ & $\mathrm{ppm}$ & 4420 & 5342 & 4881 & 652 \\
\hline $\mathrm{C}_{3} \mathrm{H}_{8}$ & $\mathrm{ppm}$ & 10.1 & 17.6 & 13.9 & 5.3 \\
\hline $\mathrm{C}_{3} \mathrm{H}_{6}$ & $\mathrm{ppm}$ & 0 & 0 & 0 & 0 \\
\hline 1-butene & $\mathrm{ppm}$ & 0 & 0 & 0 & 0 \\
\hline 1,3-butadiene & $\mathrm{ppm}$ & 0 & 0 & 0 & 0 \\
\hline 1-pentene & $\mathrm{ppm}$ & 0 & 0 & 0 & 0 \\
\hline 1-hexene & $\mathrm{ppm}$ & 0 & 0 & 0 & 0 \\
\hline Benzene & $\mathrm{ppm}$ & 6.31 & 1.92 & 4.11 & 3.10 \\
\hline Total HC & $\mathrm{ppm}$ & 9490 & 9714 & 9602 & \\
\hline
\end{tabular}

The gas samples that were analyzed to produce the results shown in Table 4.3 were collected in glass gas chromatograph sample vessels after the vessels were purged of residual air for 5 minutes. Water was removed from the gas stream sent to the sample vessels by condensation in a tube filled with quartz wool submerged in an ice bath. As seen in Table 4.3, the gas concentrations of hydrogen and carbon monoxide averaged $36.18 \%$ and $21.18 \%$, respectively. These concentrations of hydrogen and carbon monoxide are suitable for use in a SOFC. The nitrogen concentration of the samples averaged $40.64 \%$. This amount of nitrogen was the result of the use of dry air (78.1\% nitrogen) to operate at an O/C of 0.60 from air for the catalytic partial oxidation reactions occurring in the reforming reactor. Also, nitrogen was used as the carrier gas in the fuel vaporization system. The small amount of oxygen $(0.52 \%$ average) present in the samples was not present in the reformate sent to the anode of the SOFC, but was 
an artifact of the purging and use of sample vessels. The total amount of hydrocarbons left unreformed averaged $0.96 \%$. The small amounts of methane, ethane, and propane present in the reformate were assumed to be converted to syngas in the SOFC by the LSRZ catalyst applied to the anode. Notice how the ethane concentration decreased (from 577 ppm to 392 ppm) and the ethylene concentration increased (from 4420 ppm, to 5342 ppm) in the 12 minutes between the samples. This was the result of a slight pressure increase in the system during sample collection that reduced the $\mathrm{O} / \mathrm{C}$ from water being sent to the reforming reactor. Similarly, the $\mathrm{CO}_{2}$ concentration decreased from $0.719 \%$ to $0.303 \%$ between the two samples, indicating that less water-gas shift (WGS) occurred during collection of the second sample. This was the result of a decreased amount of water available for WGS due to the increased pressure associated with the sample collection procedure. These results help to demonstrate how sensitive the humidifier system was to pressure changes.

\subsection{SOFC Operation on Reformed Ultra-Low-Sulfur Diesel Fuel 1 (ULSD 1)}

The reactor was first fed $n$-tetradecane at a flowrate of $0.096 \mathrm{~mL} / \mathrm{min}$ with nitrogen and humidified air at a total flowrate of 400 sccm (Run 5 Table 4.1) and the reformed mixture was then sent to the anode of the fuel cell. The SOFC was operated on reformed $n$-tetradecane for approximately 23 hours before the liquid was switched to ULSD 1. The diesel fuel at a flowrate of $0.084 \mathrm{~mL} / \mathrm{min}$ was injected into the reactor with nitrogen and humidified air at a total flowrate of 350 sccm (Run 6 Table 4.1) and the reformed mixture was sent to the anode of the fuel cell. 
The LSRZ catalyst was used in the fuel reformer and on the SOFC anode. The SOFC voltage at $800^{\circ} \mathrm{C}$ as a function of time under a constant current load of $0.50 \mathrm{~A} \mathrm{~cm}^{-2}$ is shown in Figure 4.15:

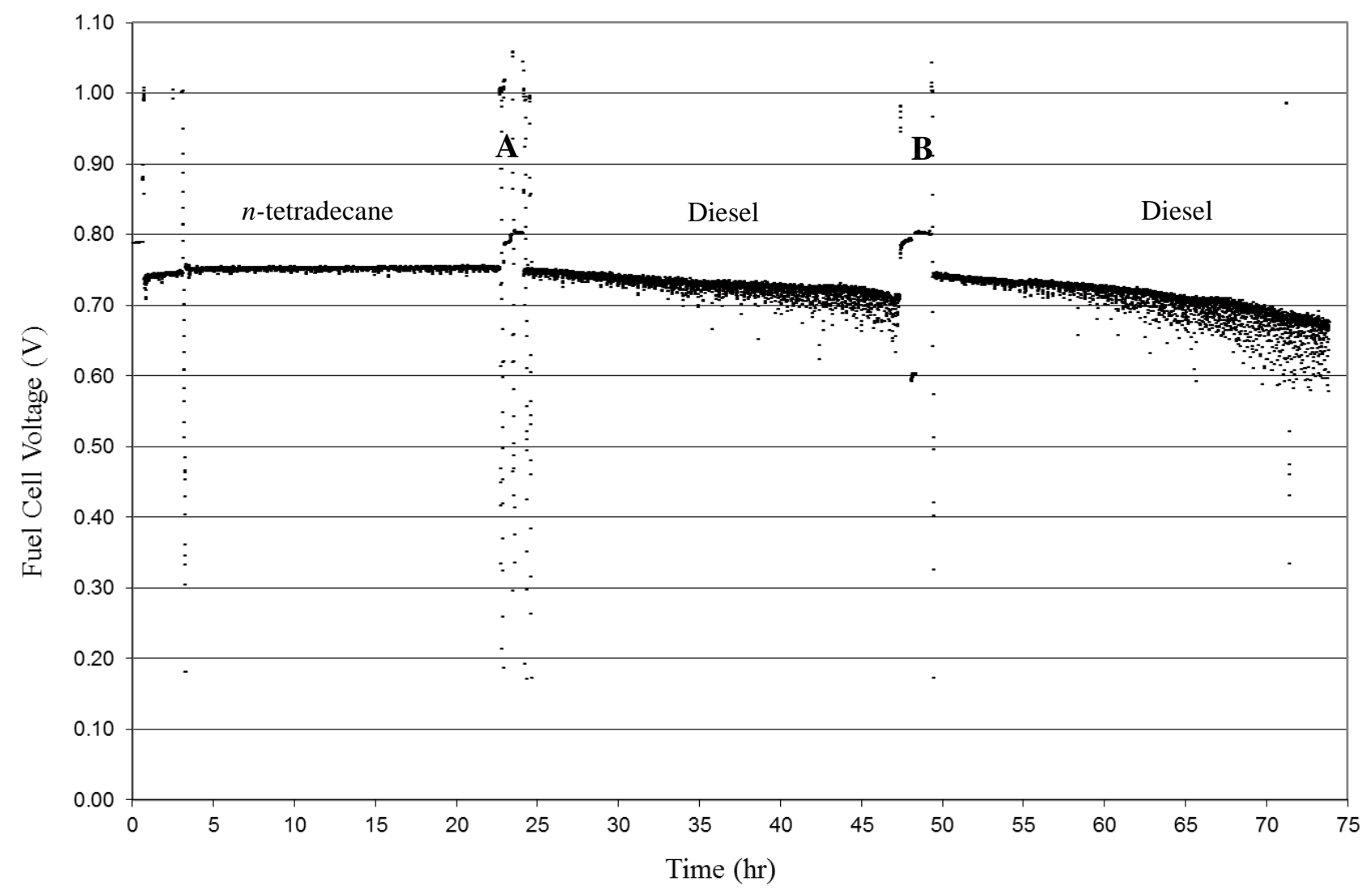

Figure 4.15. SOFC voltage at $800^{\circ} \mathrm{C}$ under a current load of $0.50 \mathrm{~A} \mathrm{~cm}^{-2}$ for $0.096 \mathrm{~mL} / \mathrm{min}$ reformed $n$ tetradecane and $0.084 \mathrm{~mL} / \mathrm{min}$ ULSD 1 using LSRZ catalyst in the reformer and on the SOFC anode.

The fuel cell was allowed to stabilize on hydrogen and a V/I curve was taken before reformed tetradecane was sent to the anode of the fuel cell. Tetradecane was reformed during $0<\mathrm{t}<23$. The $\mathrm{O} / \mathrm{C}$ ratio for air was 0.7 and the $\mathrm{O} / \mathrm{C}$ ratio for water was 0.9 , yielding an overall O/C ratio of 1.6 (Run 5 Table 4.1). The cell voltage was stable for the 22 hours of operation. At point A designated on Figure 4.15, the cell was switched to hydrogen while the HPLC pump was purged of tetradecane and switched to the diesel supplied by NETL. 
ULSD 1 was reformed during $24<\mathrm{t}<47$. The $\mathrm{O} / \mathrm{C}$ ratio for air was 0.7 and the $\mathrm{O} / \mathrm{C}$ ratio for water was 0.9, yielding an overall O/C ratio of 1.6 (Run 6 Table 4.1). A V/I curve was taken after the system stabilized (data set 1 on Figure 4.16). The cell performance degraded over the 23-hour testing period. Also, the reactor pressure increased over the course of the run. It was suspected that carbon formation in the mixing zone in the reactor before the reaction zone was the cause of the pressure increase and the reduced fuel cell performance. The fuel cell was switched to hydrogen while the pump was shut off at point B designated on Figure 4.15. During this time, the humidified air stream was sent to the reactor to oxidize the carbon formation. The dry air flow was $275 \mathrm{sccm}$ and was humidified to a relative humidity of $20 \%$, totaling a flow of about $346 \mathrm{sccm}$. After the reforming reactor was operated under these conditions for about 2 hours, the pump was turned back on and the reformed diesel was sent to the anode of the fuel cell.

ULSD 1 was reformed for the period $49<\mathrm{t}<74$ under the same conditions as those listed previously (Run 7 Table 4.1). Once again, a V/I curve was taken after the system stabilized at 49 hours (data set 2 on Figure 4.16). The results of the V/I curve were similar to the first V/I curve, but slightly lower voltages were observed. The degradation in SOFC performance was similar to the previous run, but a more substantial loss in voltage was observed. Again, it is suspected that carbon formation due to incomplete reforming was the cause of the pressure increase and the reduced fuel cell performance. Also, the catalyst may be deactivating at this point. The fuel cell was switched to hydrogen while the pump was shut off and the reactor was burned out overnight. The run was not successful. It is suspected that the catalyst may have deactivated to some extent during the runs with a low O/C ratio from air. The V-I-P data for the two ULSD 1 runs and 100 sccm hydrogen are plotted in Figure 4.16: 


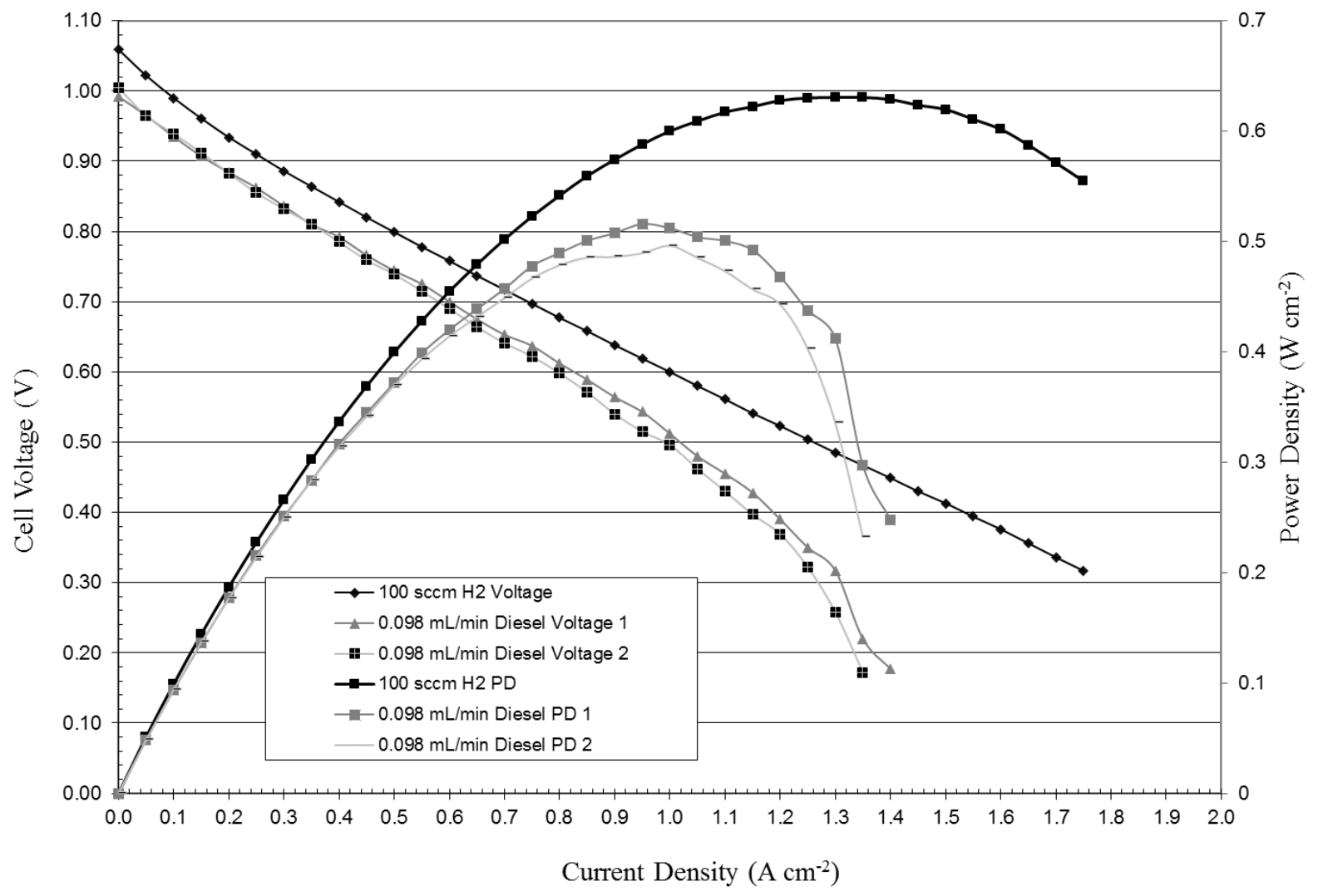

Figure 4.16. Comparison of SOFC performance at $800^{\circ} \mathrm{C}$ with pure hydrogen and reformed ULSD 1 at 25 hours and 49 hours using NETL LSRZ catalyst in the reformer and on the SOFC anode. 


\subsection{SOFC Operation on Reformed FAME Mixture}

First, hydrogen at a flowrate of $100 \mathrm{sccm}$ was sent to the SOFC anode for a short time during startup. The FAME mixture was sent to the reforming reactor at a flowrate of 0.116 $\mathrm{mL} / \mathrm{min}$ with nitrogen and humidified air at a total flowrate of $450 \mathrm{sccm}$ using the NETL LSRZ catalyst in the fuel reforming reactor. The $\mathrm{O} / \mathrm{C}$ from air was 1.00 , the $\mathrm{O} / \mathrm{C}$ from water was 0.40 , and the $\mathrm{O} / \mathrm{C}$ present in the fuel was 0.113 , totaling an overall $\mathrm{O} / \mathrm{C}$ of 1.513 for the reforming conditions (Run 13 and Run 14 Table 4.1). The reformate was then sent to the SOFC anode, which had a thin layer of the LSRZ catalyst applied, without any sample conditioning done between the reformer outlet and the SOFC anode inlet. The SOFC voltage and reformer pressure as a function of time under a current load of $0.50 \mathrm{~A} \mathrm{~cm}^{-2}$ is shown in Figure 4.17:

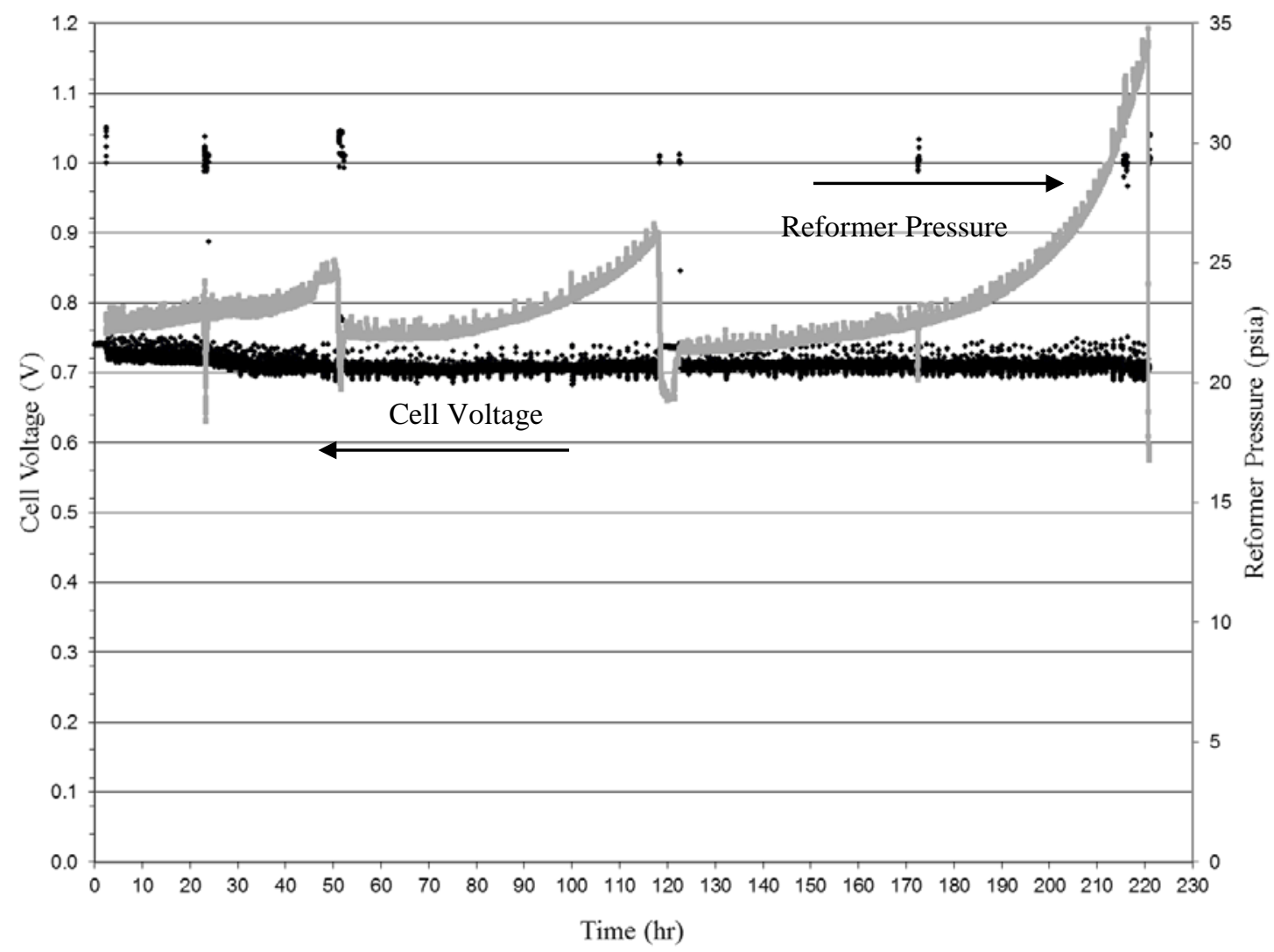

Figure 4.17. Reformer pressure and SOFC voltage at $800^{\circ} \mathrm{C}$ under a current load of $0.50 \mathrm{~A} \mathrm{~cm}^{-2}$ for 0.116 $\mathrm{mL} / \mathrm{min}$ reformed FAME mixture using LSRZ catalyst in the reformer and on the SOFC anode. 
As seen in Figure 4.17, the SOFC system was operated for a total time of 220 hours on the reformed FAME mixture. The experiment was comprised of two runs. First, the system was operated for 118 hours with gas sample collection at 0 hours and 23 hours and a 40 minute reactor coking oxidation at 51 hours (Run 13 Table 4.1). The SOFC voltage remained very stable for the entire run. The reforming reactor pressure was monitored and recorded during the run and increased for the entirety of the experiment. At 118 hours the SOFC was switched to 100 sccm pure hydrogen and the liquid fuel pump was shut off to oxidize carbon buildup in the reactor for a total time of 3 hours and 30 minutes. At 122 hours the liquid fuel pump was switched back on and the SOFC began to operate on the reformed FAME mixture once again (Run 14 Table 4.1). At 172 hours the air cylinder was nearly depleted and had to be changed for a full one. Gas samples were collected at 215 hours. The SOFC was successfully operated on the reformed FAME mixture continuously for the objective 100 hours. The SOFC voltage was stable for the entire run, but the reformer pressure began to rise very rapidly near the end of the run. At 222 hours the pressure in the reforming reactor reached a value which necessitated shut down. Further operation would have caused significant pressures that would have limited the amount of water introduced into the reactor by the heated humidifier, thereby causing even more carbon deposition in the reactor. 
The V-I-P data collected at the beginning of the run for pure hydrogen and reformed FAME mixture after one hour on-stream are shown in Figure 4.18:

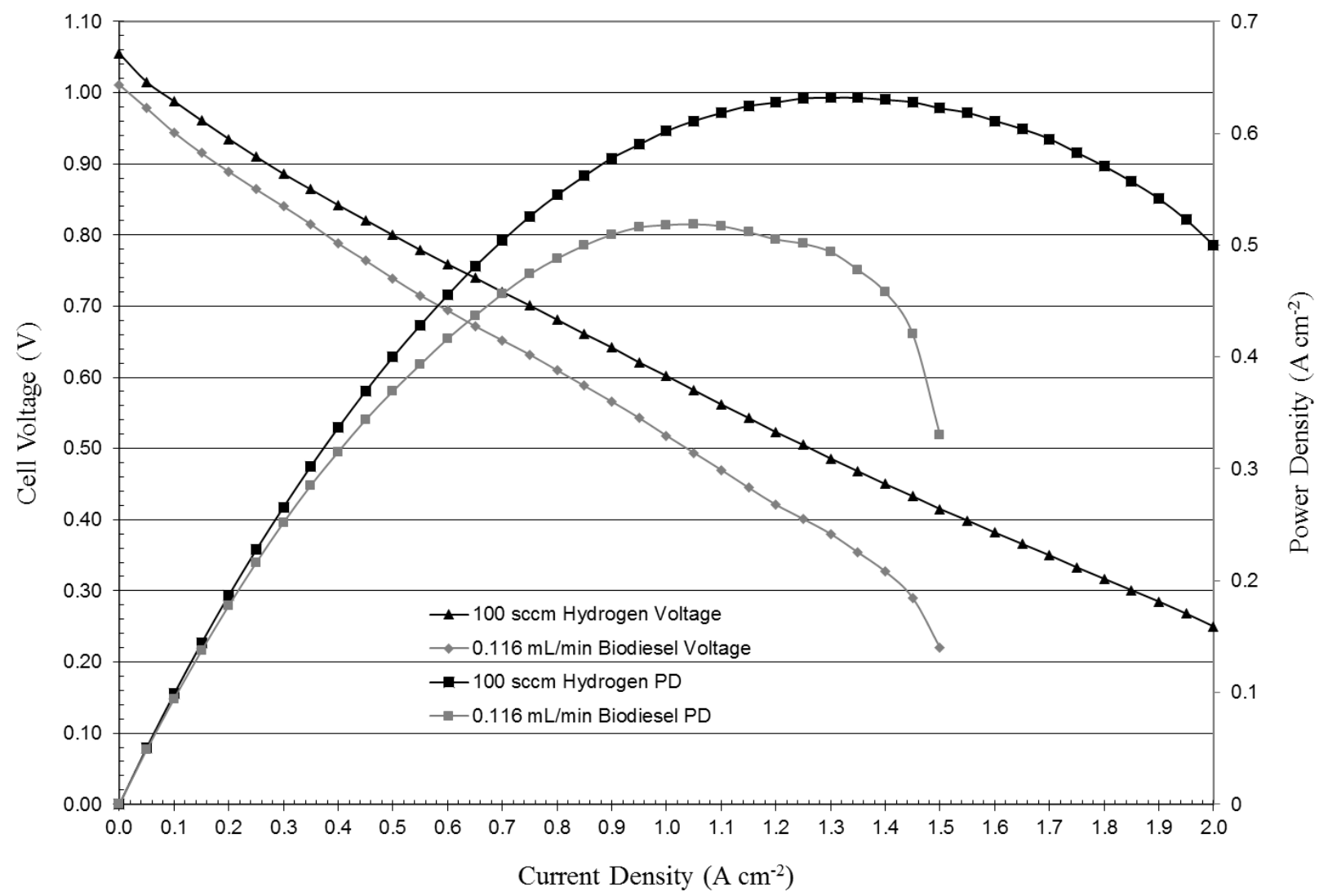

Figure 4.18. Comparison of SOFC performance at $800^{\circ} \mathrm{C}$ with pure hydrogen and reformed FAME mixture at one hour using NETL LSRZ catalyst in the reformer and on the SOFC anode. 
Gas samples collected at 0 hours, 23 hours, and 215 hours were sent for GC analysis and the results are shown in Table 4.4:

Table 4.4. Gas chromatograph analysis of reformed FAME mixture.

\begin{tabular}{|l|l|r|r|r|r|r|}
\hline $\begin{array}{l}\text { Sample } \\
\text { No. }\end{array}$ & & \multicolumn{1}{c|}{1} & \multicolumn{1}{c|}{2} & \multicolumn{1}{c|}{3} & \multicolumn{1}{c|}{4} & \multicolumn{1}{c|}{5} \\
\hline Time (hr) & & 0 & 0 & 23 & 215 & \multicolumn{1}{c|}{215} \\
\hline & & & & & & \\
\hline $\mathrm{H}_{2}$ & $\%$ & 25.39 & 10.00 & 23.35 & 25.88 & 24.33 \\
\hline $\mathrm{CO}_{2}$ & $\%$ & 4.99 & 3.59 & 3.28 & 3.02 & 3.12 \\
\hline $\mathrm{O}_{2}$ & $\%$ & 0.78 & 4.27 & 0.49 & 0.58 & 0.62 \\
\hline $\mathrm{N}_{2}$ & $\%$ & 48.35 & 63.56 & 49.93 & 46.37 & 48.74 \\
\hline $\mathrm{CO}$ & $\%$ & 20.11 & 18.26 & 22.51 & 23.57 & 22.67 \\
\hline $\mathrm{CH}_{4}$ & $p p m$ & 3649 & 3114 & 4353 & 5609 & 4942 \\
\hline $\mathrm{C}_{2} \mathrm{H}_{6}$ & $p p m$ & 66.1 & 54.1 & 113.9 & 169.3 & 150.4 \\
\hline $\mathrm{C}_{2} \mathrm{H}_{4}$ & $p p m$ & 2.3 & 0.0 & 0.0 & 7.6 & 3.3 \\
\hline $\mathrm{C}_{3} \mathrm{H}_{8}$ & $p p m$ & 0.0 & 0.0 & 1.9 & 3.6 & 1.9 \\
\hline $\mathrm{C}_{3} \mathrm{H}_{6}$ & $p p m$ & 0.0 & 0.0 & 0.0 & 4.2 & 0.0 \\
\hline $\mathrm{C}_{6} \mathrm{H}_{6}$ & $p p m$ & 104.0 & 27.9 & 6.5 & 3.2 & 30.5 \\
\hline $\mathrm{Total}_{1} \mathrm{HC}$ & $p p m$ & 3821 & 3196 & 4475 & 5797 & 5129 \\
\hline
\end{tabular}

As seen in Table 4.4, the first sample collected at 0 hours had similar gas concentrations compared to the samples collected at 23 hours and 215 hours. The second sample collected at 0 hours showed lower concentrations of the gas species of interest and higher concentrations oxygen and nitrogen, meaning that the vessel leaked during transport to the GC for analysis. For the good samples, the gas concentrations of hydrogen and carbon monoxide averaged $24.74 \%$ and $22.22 \%$, respectively. These concentrations of hydrogen and carbon monoxide are suitable for use in a SOFC. The nitrogen concentration of the good samples averaged $48.35 \%$. This high concentration of nitrogen was due to the large amount of air used to operate at an $\mathrm{O} / \mathrm{C}$ of 1.0 from air for the catalytic partial oxidation reactions occurring in the reforming reactor. Also, nitrogen was used as the carrier gas in the fuel vaporization system. The small amount of 
oxygen present in the samples was not present in the reformate sent to the anode of the SOFC, but was an artifact of the purging and use of sample vessels. The small amounts of methane and ethane present in the reformate were presumed to be converted to syngas in the SOFC by the LSRZ catalyst applied to the anode. Only a very small amount of ethylene was detected in the gas samples. In comparison, the samples collected during operation at high reformer pressure (215 hours) compared to lower reformer pressure ( 0 and 23 hours) had similar $\mathrm{H}_{2}$ and $\mathrm{CO}$ concentrations but higher hydrocarbon concentrations, most notably higher methane and ethane concentrations. This shows that the reforming catalyst was still operating properly and the pressure increase was most likely due to thermal decomposition of the FAME mixture in both the vaporization system and the mixing zone before the reaction zone in the reforming reactor. Operation of the vaporization system at a lower temperature would have probably prevented this. 


\subsection{SOFC Operation on Reformed Ultra-Low-Sulfur Diesel Fuel 2 (ULSD 2)}

A second ULSD sample (henceforth referred to as ULSD 2) was tested in the reformer/SOFC system after the successful 100-hour operation on the FAME mixture. The same LSRZ catalyst used for the FAME mixture experiments was used in the reforming reactor and also on the anode of the SOFC. The SOFC voltage under a current load of $0.50 \mathrm{~A} \mathrm{~cm}^{-2}$ and the reformer pressure as a function of time for the first run of ULSD 2 is shown in Figure 4.19:

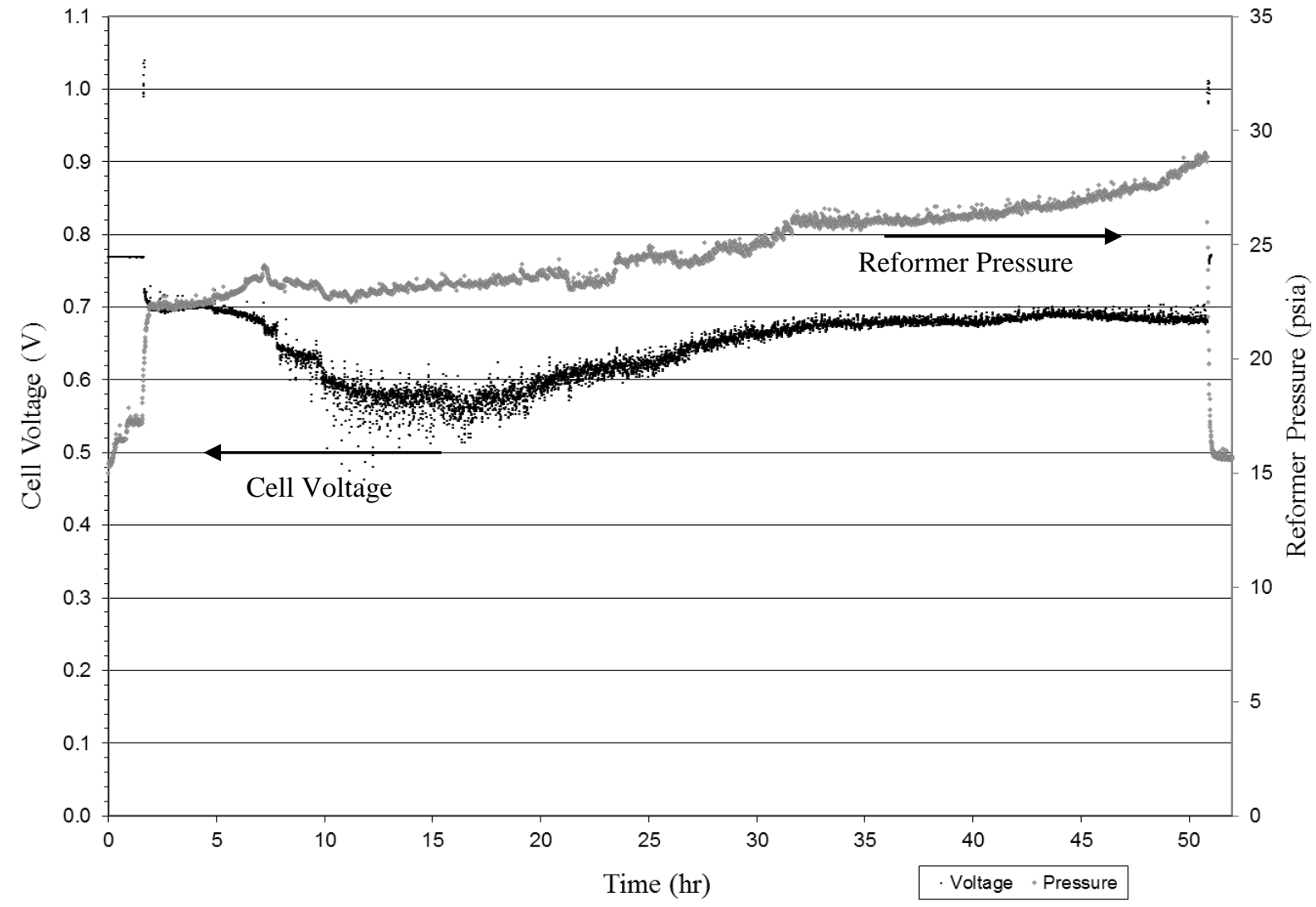

Figure 4.19. Reformer pressure and SOFC voltage at $800^{\circ} \mathrm{C}$ under a current load of $0.50 \mathrm{~A} \mathrm{~cm}^{-2}$ for 0.099 $\mathrm{mL} / \mathrm{min}$ reformed ULSD 2 using the LSRZ catalyst in the reformer and on the SOFC anode.

First, hydrogen at a flowrate of 100 sccm was sent to the SOFC anode for a short time during startup to verify proper cell performance. The diesel was sent to the reforming reactor at a flowrate of $0.099 \mathrm{~mL} / \mathrm{min}$ with nitrogen and humidified air at a total flowrate of $450 \mathrm{sccm}$ 
using the NETL LSRZ catalyst in the fuel reforming reactor. The O/C from air was 1.00 and the $\mathrm{O} / \mathrm{C}$ from water was 0.50 , totaling an overall $\mathrm{O} / \mathrm{C}$ of 1.50 for the reforming conditions (Run 16 Table 4.1). The diesel reformate was then sent to the SOFC anode, which had a thin layer of the LSRZ catalyst applied, without any sample conditioning done between the reformer outlet and the SOFC anode inlet.

As seen in Figure 4.19, the reformer pressure is plotted in gray and the SOFC voltage is plotted in black. The reformer pressure increased steadily with time during the 50 hour experiment and eventually became so high that the experiment had to be shut down. The cell voltage decreased from 2 hours until 12 hours. At this point the cell voltage stabilized for a short time before increasing, while the reformer pressure continued to increase. From 17 hours till 30 hours both the cell voltage and reformer pressure increased. Also during this time, the temperature of the humidifier was increased in accordance with reformer pressure. It was believed that the increase in water temperature allowed for more water to be introduced into the system and hence facilitated a higher $\mathrm{O} / \mathrm{C}$ from water and allowed the diesel to be reformed more efficiently. From 30 hours to 50 hours, the cell voltage was relatively stable. The reformer pressure increased steadily during this time period but started to increase rapidly during the final few hours of the experiment and necessitated shut down. The cell was switched to hydrogen and allowed to cool to room temperature. Extensive coking was found on the anode upon removal of the cell from the SOFC, even with the LSRZ catalyst coating, as shown in Figure 4.20: 


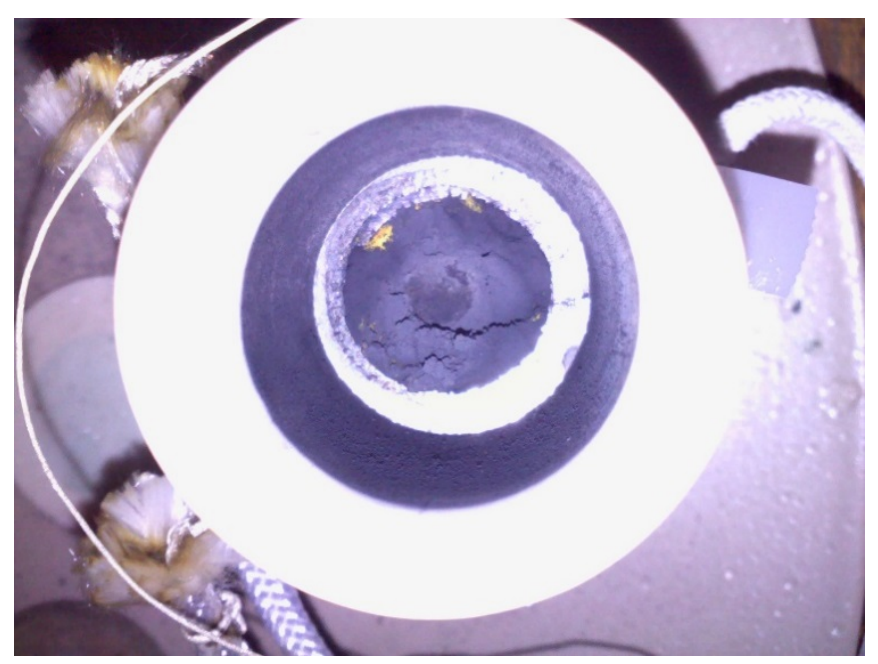

Figure 4.20. Picture of the SOFC anode after 50-hour operation on reformed ULSD 2.

The coking found on the SOFC anode was believed to be due to incomplete reforming of the diesel. This could have been due to improper reforming conditions from a lack of water in the system or inadequate vaporization of the diesel fuel.

A second experiment was performed using the same diesel fuel (ULSD 2) and LSRZ catalyst, for comparison (Run 17 Table 4.1). The SOFC voltage under a current load of $0.50 \mathrm{~A}$ $\mathrm{cm}^{-2}$ and the reformer pressure as a function of time for the second run of the new diesel fuel using the LSRZ catalyst is shown in Figure 4.21: 


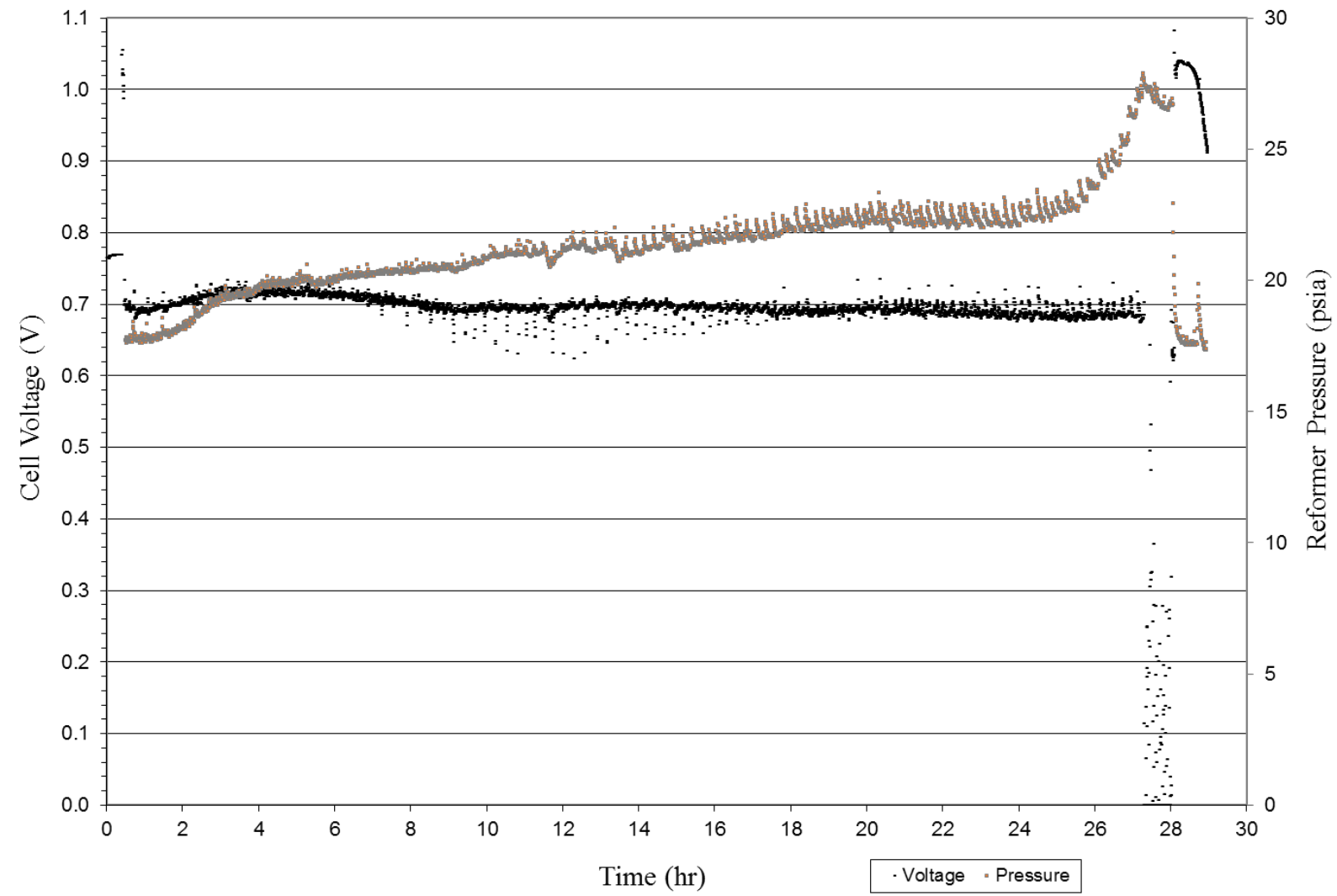

Figure 4.21. Reformer pressure and SOFC voltage at $800^{\circ} \mathrm{C}$ under a current load of $0.50 \mathrm{~A} \mathrm{~cm}^{-2}$ for 0.099 $\mathrm{mL} / \mathrm{min}$ reformed ULSD 2 using LSRZ catalyst in the reformer and on the SOFC anode.

As seen in Figure 4.21, the reformer pressure is plotted in gray and the SOFC voltage is plotted in black. The cell voltage decrease steadily over the 27 hour run. The reformer pressure increased rapidly for the first four hours, then increased steadily for the next twenty hours, but then started to increase very rapidly for the final 3 hours before the experiment was shut down. This second run of the ULSD 2 fuel using the LSRZ catalyst showed improved results compared to the first run, but ultimately exhibited a similar rapid pressure increase before being forced to shut down. Once again, improper reforming or inadequate vaporization was suspected to be the cause of the pressure increase. 


\subsection{Comparison of Experiments}

Different operating conditions were utilized during experimentation of the reforming reactor. A listing of the different reforming reactor operating conditions are listed in Table 4.1 (Chapter 4.2).

It is believed that the coking seen on the SOFC anode after Run 16 and Run 17 of the ULSD 2 fuel was the result of pyrolysis of the diesel fuel in the both the vaporization system and the mixing zone before the reaction zone in the reforming reactor. The temperature of the vaporization furnace was increased from $375^{\circ} \mathrm{C}$ to $425^{\circ} \mathrm{C}$ from the runs of ULDS 1 (Run 6 and Run 7 in Table 4.1) to the runs of ULSD 2 (Run 15 and Run 16 Table 4.1). The temperature of the vaporization furnace was further increased to $450^{\circ} \mathrm{C}$ for the final ULSD 2 experiment (Run 17 Table 4.1). This in turn led to a decrease in the operation time until pressure increases in the system necessitated shut down from 48 hours (Run 16 Table 4.1) to 26 hours (Run 17 Table 4.1).

Pyrolysis of the vaporized fuel was not unique to the case of ULSD 2. It was also believed to happen during the FAME mixture experiments (Runs 13 and 14 Table 4.1). It is speculated that the pressure increases seen in the FAME mixture experiments were due to thermal decomposition of the vaporized fuel in both the vaporization system and the mixing zone before the reaction zone in the reforming reactor. Although biodiesel-like fuels typically have a boiling point range of $315^{\circ} \mathrm{C}-350^{\circ} \mathrm{C}$, a temperature of $425^{\circ} \mathrm{C}$ was chosen for the vaporization system to ensure complete vaporization. This value is in contrast to the temperature used in the literature of $350^{\circ} \mathrm{C}$ [67]. However, the article was not published until over a year after the FAME mixture experiments were performed. 
The SOFC voltage remained stable during operation with the reformed FAME mixture, similar to the results found by the experiments performed by Siefert, et al. [67]. However, no pressure increases were seen in the reforming reactor during the experiments listed in the literature. This was the due to the absence of thermal decomposition of the vaporized liquid fuel as the result of the lower vaporization temperature. Also, a different catalyst configuration was utilized for the experiments performed in the literature. The same LSRZ catalyst was used, but was deposited onto a square-channel alumina monolith with a zirconia-doped-ceria (ZDC) interlayer for enhanced oxygen transport [67]. The use of a ZDC interlayer between support and catalyst has been shown to reduce catalyst deactivation by providing localized oxygen to aid in the gasification of adsorbed carbon on the catalyst active sites [70].

It would have been interesting to see if the experiments performed in the literature [67] experienced the same steep drop in voltage at high current densities as seen in this work, but data was only provided for a relatively short range. 


\section{Conclusions and Future Work}

A fuel vaporization system, fuel reforming reactor, and a high-temperature SOFC testing system were designed, fabricated, and integrated for performance testing of reformed low-sulfur liquid fuels in the SOFC system. It was found that the reformer/SOFC system could be operated on low-sulfur liquid fuels using a new LSRZ catalyst developed by the U.S. Department of Energy’s National Energy Technology Laboratory (NETL) in Morgantown, West Virginia.

A desulfurized version of the military logistic fuel JP-8 containing 11.7 ppm of thiophenic sulfur was successfully reformed and utilized in the SOFC for a total time of 93 hours before pressure increases in the reactor caused problems. The sulfur-free compound $n$ tetradecane was successfully reformed multiple times for periods of up to 50 hours with no pressure increases in the reactor. Sulfur-free biodiesel was successfully reformed and operated in the SOFC for 100 hours and only incurred slight pressure increases during the first 60 hours but ultimately did show pressure increases in the reactor that necessitated system shut down. Two different ultra-low-sulfur diesel fuels with thiophenic sulfur contents of $14.2 \mathrm{ppm}$ and 11.6 ppm were tested. Both diesel fuels caused the reforming reactor pressure to increase and eventually required system shut down within 30 hours of operation. The pressure increases seen during the biodiesel and ULSD 2 runs were believed to be the result of fuel pyrolysis in both the vaporization system and the mixing zone before the reaction zone in the reforming reactor due to the vaporization system operating a too high of a temperature.

Since it was later found by GC analysis that the reformate sent to the SOFC anode had a nitrogen content of about 50\%, it would have been better to use hydrogen diluted with nitrogen to a concentration of $50 \%$ instead of pure hydrogen for the performance comparisons shown in 
the V-I-P diagrams. The large amount of nitrogen present in the reformate led to a decrease in the performance of the SOFC, especially at higher current densities, where mass transfer limited the amount of $\mathrm{H}_{2}$ and $\mathrm{CO}$ available for utilization at the SOFC anode.

The increase of pressure in the reactor was of major concern because of the use of a heated humidifier in the system. Air was sent through the heated humidifier and carried water to the reactor. As the pressure in the reactor increased, so did the pressure of the air in the humidifier. This changed the water/air equilibrium in the humidifier and thus decreased the amount of water being sent to the reactor at the set temperature. To maintain the $\mathrm{O} / \mathrm{C}$ ratio required for oxidative steam reforming from the water being sent to the reactor from the humidified air stream, the humidifier temperature had to be increased accordingly to the pressure increase in the reactor. This was found to be problematic during operation when pressure increases in the reactor occurred. It was concluded that for future experiments a pump should be used to inject liquid water into a system similar to the fuel vaporization system, to avoid the problem with pressure increases affecting the water delivery system. However, a second pump was unavailable during the experimentation, so the temperature of the humidifier was adjusted as often as necessary until the humidifier heating system reached near-100\% operation and the temperature could not be increased any more.

The use of liquid fuels that are complex mixtures can cause vaporization problems, due to the varying boiling points of the component molecules. It was concluded that the liquid fuel must be introduced drop-wise into the vaporization system in the smallest droplets possible. Also, the vaporization temperature must be optimized for each liquid fuel. 
It was determined that parametric studies would have been beneficial to this work. An attempt was made to incorporate an in-line gas chromatograph (GC) for reformate analysis, but the system was not functional. The use of a GC would have allowed for the reforming parameters to be optimized for hydrogen and carbon monoxide selectivity. There was inadequate gas sampling during the course of the work due to limited access to a GC for sample analysis. An in-line GC would have also allowed for temperature programmed oxidation (TPO) experiments on the carbons deposited in the reforming reactor. TPO profiles would have helped to determine whether the pressure increases seen in the reforming system were the result of thermal decomposition of the vaporized fuels before the reaction zone or coke formation on the catalyst.

It was found that the application of a thin layer of the LSRZ catalyst to the SOFC anode using a Ni-based paste significantly reduced carbon formation on the anode caused by gaseous hydrocarbons left over from the reforming process. This new application for the LSRZ catalyst promoted in-situ reforming on the SOFC anode, allowing the cell to operate more consistently throughout the experiments.

In the future, the LSRZ catalyst should be further explored through testing under different catalytic partial oxidation, steam reforming, and oxidative steam reforming conditions to determine the best operating conditions for use in a SOFC. Also, it could undergo further development to withstand higher sulfur concentrations, such as those present in coal syngas, for additional applications. The use of the LSRZ catalyst, particularly with an oxygen promoter, on the anode of a high-temperature SOFC has potential for further research and development, as this could possibly lead to a singular device capable of in-situ reforming and fuel cell operation. 


\section{References}

[1] U.S. Energy Information Administration Annual Energy Review http://www.eia.gov/totalenergy/data/annual/ (2011)

[2] NETL Clean Coal Power Initiative Fact Sheet http://www.netl.doe.gov/publications/factsheets/program/Prog052.pdf (2011)

[3] S. C. Singhal. “Advances in solid oxide fuel cell technology.” Solid State Ionics 135 (2000): 305-313.

[4] M. Li, A.D. Rao, J. Brouwer, G.S. Samuelsen. "Design of highly efficient coal-based integrated gasification fuel cell power plants.” Journal of Power Sources 195 (2010): 5707-5718.

[5] M.C. Williams, J.P. Strakey, W.A. Surdoval, L.C. Wilson. "Solid oxide fuel cell technology development in the U.S.” Solid State Ionics 177 (2006): 2039-2044.

[6] J. Van herle, Y. Membrez, O. Bucheli. "Biogas as a fuel source for SOFC cogenerators.” Journal of Power Sources 127 (2004): 300-312.

[7] A.L. Dicks. "Hydrogen generation from natural gas for the fuel cell systems of tomorrow.” Journal of Power Sources 61 (1996): 113-124.

[8] Y. Lin, Z. Zhan, J. Liu, S.A. Barnett. "Direct operation of solid oxide fuel cells with methane fuel.” Solid State Ionics 176 (2005): 1827-1835.

[9] M. Krumpelt, T.R. Krause, J.D. Carter, J.P. Kopasz, S. Ahmed. "Fuel processing for fuel cell systems in transportation and portable power applications.” Catalysis Today 77 (2002): 3-16. 
[10] L.J. Pettersson, R. Westerholm. "State of the art of multi-fuel reformers for fuel cell vehicles: problem identification and research needs.” International Journal of Hydrogen Energy 26 (2001): 243-264.

[11] B. Lindstrom, J.A.J. Karlsson, P. Ekdunge, L. De Verdier, B. Haggendal, J. Dawody, M. Nilsson, L.J. Pettersson. "Diesel fuel reformer for automotive fuel cell applications.” International Journal of Hydrogen Energy 34 (2009): 3367-3381.

[12] J. Lawrence, M. Boltze. "Auxiliary power unit based on a solid oxide fuel cell and fuelled with diesel.” Journal of Power Sources 154 (2006): 479-488.

[13] Y. Yi, A.D. Rao, J. Brouwer, G.S. Samuelsen. "Fuel flexibility study of an integrated 25kW SOFC reformer system.” Journal of Power Sources 144 (2005): 67-76.

[14] P.K. Cheekatamarla, C.M. Finnerty, C.R. Robinson, S.M. Andrew, J.A. Brodie, Y. Lu, P.G. DeWald. "Design, integration and demonstration of a 50W JP8/kerosene fueled portable SOFC power generator.” Journal of Power Sources 193 (2009): 797-803.

[15] J. Larminie, A. Dicks. Fuel Cell Systems Explained. J. Wiley \& Sons. 2003.

[16] D.J. Moon, K. Sreekumar, S.D. Lee, B.G. Lee, H.S. Kim. "Studies on gasoline fuel processor system for fuel-cell powered vehicles application.” Applied Catalysis A: General 215 (2001): 1-9.

[17] A. Lindermeir, S. Kah, S. Kavurucu, M. Muhlner. "On-board diesel fuel processing for an SOFC-APU - Technical challenges for catalysis and reactor design.” Applied Catalysis B: Environmental 70 (2007): 488-497.

[18] Y. Matsuzaki, Y. Baba, T. Sakurai. "High electric conversion efficiency and electrochemical properties of anode-supported SOFCs.” Solid State Ionics 174 (2004): 81-86. 
[19] R.J. Gorte, H. Kim, J.M. Vohs. "Novel SOFC anodes for the direct electrochemical oxidation of hydrocarbon.” Journal of Power Sources 106 (2002): 10-15.

[20] A. Gunji, C. Wen, J. Otomo, T. Kobayashi, K. Ukai, Y. Mizutani, H. Takahashi. “Carbon deposition behaviour on Ni-ScSZ anodes for internal reforming solid oxide fuel cells.” Journal of Power Sources 131 (2004): 285-288.

[21] P. Leone, A. Lanzini, G.A. Ortigoza-Villalba, R. Borchiellini. “Operation of a solid oxide fuel cell under direct internal reforming of liquid fuels.” Chemical Engineering Journal 191 (2012): 349-355.

[22] H. Kishimoto, K. Yamaji, T. Horita, Y. Xiong, N. Sakai, M.E. Brito, H. Yokokawa. “Feasibility of liquid hydrocarbon fuels for SOFC with Ni-ScSZ anode.” Journal of Power Sources 172 (2007): 67-71.

[23] C.H. Bartholomew, P.K. Agrawal, J.R. Katzer. “Sulfur poisoning of metals.” Advances in Catalysis 31 (1982): 135-242.

[24] D. Shekhawat, T.H. Gardner, D.A. Berry, M. Salazar, D.J. Haynes, J.J. Spivey. “Catalytic partial oxidation of $n$-tetradecane in the presence of sulfur or polynuclear aromatics: Effects of support and metal.” Applied Catalysis A: General 311 (2006): 816.

[25] D.J. Haynes, D.A. Berry, D. Shekhawat, J.J. Spivey. “Catalytic partial oxidation of ntetradecane using Rh and Sr substituted pyrochlores: Effects of sulfur.” Catalysis Today 145 (2009): 121-126. 
[26] J.P. Trembly, R.S. Gemmen, D.J. Bayless. “The effect of IGFC warm gas cleanup systems conditions on the gas-solid partitioning and form of trace species in coal syngas and their interactions with SOFC anodes.” Journal of Power Sources 163 (2007): 986996.

[27] C. Xu, J.W. Zondlo, M. Gong, F. Elizalde-Blancas, X. Liu, I.B. Celik. "Tolerance tests of $\mathrm{H}_{2} \mathrm{~S}$-laden biogas fuel on solid oxide fuel cells.” Journal of Power Sources 195 (2010): 4583-4592.

[28] J.N. Kuhn, N. Lakshminarayanan, U.S. Ozkan. "Effect of hydrogen sulfide on the catalytic activity of Ni-YSZ cermets.” Journal of Molecular Catalysis A: Chemical 282 (2008): 9-21.

[29] Y. Matsuzaki, I. Yasuda. "The poisoning effect of sulfur-containing impurity gas on a SOFC anode: Part I. Dependence on temperature, time, and impurity concentration.” Solid State Ionics 132 (2000): 261-269.

[30] F. Zaza, C. Paoletti, R. LoPresti, E. Simonetti, M. Pasquali. "Studies on sulfur poisoning and development of advance anodic materials for waste-to-energy fuel cells applications.” Journal of Power Sources 195 (2010): 4043-4050.

[31] J.P. Trembly, A.I. Marquez, T.R. Ohrn, D.J. Bayless. "Effects of coal syngas and $\mathrm{H}_{2} \mathrm{~S}$ on the performance of solid oxide fuel cells: Single-cell tests.” Journal of Power Sources 158 (2006): 263-273.

[32] F.N. Cayan, M. Shi, S.R. Pakalapati, I. Celik, N. Wu, R. Gemmen. "Effects of coal syngas impurities on anodes of solid oxide fuel cells.” Journal of Power Sources 185 (2008): 595-602. 
[33] J.F.B. Rasmussen, A. Hagen. "The effect of $\mathrm{H}_{2} \mathrm{~S}$ on the performance of Ni-YSZ anodes in solid oxide fuel cells.” Journal of Power Sources 191 (2009): 534-541.

[34] L. Zhang, S.P. Jiang, H.Q. He, X. Chen, J. Ma, X.C. Song. “A comparative study of $\mathrm{H}_{2} \mathrm{~S}$ poisoning on electrode behavior of Ni/YSZ and Ni/GDC anodes of solid oxide fuel cells.” International Journal of Hydrogen Energy 35 (2010): 12359-12368.

[35] A. Hagen, J.F.B. Rasmussen, K. Thyden. "Durability of solid oxide fuel cells using sulfur containing fuels.” Journal of Power Sources 196 (2011): 7271-7276.

[36] D.J. Haynes, A. Campos, D.A. Berry, D. Shekhawat, A. Roy, J.J. Spivey. “Catalytic partial oxidation of a diesel surrogate fuel using an Ru-substituted pyrochlore.” Catalysis Today 155 (2010): 84-91.

[37] S.M. Haile. “Fuel cell materials and components.” Acta Materialia 51 (2003): 59816000.

[38] N.Q. Minh. “Solid oxide fuel cell technology-features and applications.” Solid State Ionics 174 (2004): 271-277.

[39] D.K. Barkan. Walther Nernst and the Transition to Modern Physical Science. Cambridge University Press. 1999.

[40] J. Macek, B. Novosel, M. Marinsek. “Ni-YSZ SOFC anodes-Minimization of carbon deposition.” Journal of the European Ceramic Society 27 (2007): 487-491.

[41] J. Kim, S. Lee, S. Srinivasan, C.E. Chamberlin. "Modeling of proton exchange membrane fuel cell performance with an empirical equation.” Journal of the Electrochemical Society 142 (1995): 2670-2674. 
[42] J. Hamelin, K. Agbossou, A. Laperriere, F. Laurencelle, T.K. Bose. "Dynamic behavior of a PEM fuel cell stack for stationary applications.” International Journal of Hydrogen Energy 26 (2001): 625-629.

[43] S.C. Singhal, K. Kendall. High Temperature Solid Oxide Fuel Cells - Fundamentals, Design and Applications. Elsevier. 2003.

[44] P. Hofmann, K.D. Panopoulos. "Detailed dynamic Solid Oxide Fuel Cell modeling for electrochemical impedance spectra simulation.” Journal of Power Sources 195 (2010): 5320-5339.

[45] D. Shekhawat, J.J. Spivey, D.A. Berry, editors. Fuel Cells: Technologies for Fuel Processing. Elsevier. 2011.

[46] Y. Jamal, M.L. Wyszynksi. “On-board generation of hydrogen-rich gaseous fuels-a review.” International Journal of Hydrogen Energy 19 (1994): 557-572.

[47] A. Naidja, C.R. Krishna, T. Butcher, D. Mahajan. "Cool flame partial oxidation and its role in combustion and reforming of fuels for fuel cell systems.” Progress in Energy and Combustion Science 29 (2003): 155-191.

[48] A.F. Ghenciu. "Review of fuel processing catalysts for hydrogen production in PEM fuel cell systems.” Current Opinion in Solid State and Materials Science 6 (2002): 389-399.

[49] D. Shekhawat, D.A. Berry, D.J. Haynes, J.J. Spivey. "Fuel constituent effects on fuel reforming properties for fuel cell applications.” Fuel 88 (2009): 817-825.

[50] D.J. Haynes, D.A. Berry, D. Shekhawat, J.J. Spivey. “Catalytic partial oxidation of $n$ tetradecane using pyrochlores: Effect of Rh and Sr substitution.” Catalysis Today 136 (2008): 206-213. 
[51] D.J. Haynes, A. Campos, M.W. Smith, D.A. Berry, D. Shekhawat, J.J. Spivey. "Reducing the deactivation of Ni-metal during the catalytic partial oxidation of a surrogate diesel fuel mixture.” Catalysis Today 154 (2010): 210-216.

[52] C. Song, C.S. Hsu, I. Mochida. Chemistry of Diesel Fuels. Taylor and Francis. 2000.

[53] J. Erwin. "Assay of Diesel Fuel Components Properties and Performance.” Symposium on Processing and Product Selectivity of Synthetic Fuels, Presented before the Division of Fuel Chemistry of the American Chemical Society. (1992)

[54] U.S. Department of Defense. Detail Specification MIL-DTL-83133H. (2011)

[55] J.J. Krummenacher, L.D. Schmidt. "High yields of olefins and hydrogen from decane in short contact time reactors: rhodium versus platinum.” Journal of Catalysis 222 (2004): 429-438.

[56] A. Beretta, P. Forzatti. "Partial oxidation of light paraffins to synthesis gas in short contact-time reactors.” Chemical Engineering Journal 99 (2004): 219-226.

[57] G.J. Panuccio, K.A. Williams, L.D. Schmidt. "Contributions of heterogenous and homogeneous chemistry in the catalytic partial oxidation of octane isomers and mixtures on rhodium coated foams.” Chemical Engineering Science 61 (2006): 4207-4219.

[58] P.J. Wilde, C.R.A. Catlow. "Defects and diffusion in pyrochlore structured oxides." Solid State Ionics 112 (1998): 173-183.

[59] M.A. Subramanian, G. Aravamudan, G.V. Subba Roa. "Oxide pyrochlores - A review." Progress in Solid State Chemistry 15 (1983): 55-143.

[60] D. Sedmidubsky, O. Benes, R.J.M. Konings. "High temperature heat capacity of $\mathrm{Nd}_{2} \mathrm{Zr}_{2} \mathrm{O}_{7}$ and $\mathrm{La}_{2} \mathrm{Zr}_{2} \mathrm{O}_{7}$ pyrochlores.” The Journal of Chemical Thermodynamics 37 (2005): 1098-1103. 
[61] H. Dai, X. Zhong, J. Li, Y. Zhang, J. Meng, X. Cao. “Thermal stability of doubleceramic-layer thermal barrier coatings with various coating thickness.” Materials Science and Engineering: A 433 (2006): 1-7.

[62] H. Zhou, D. Yi, Z. Yu, L. Xiao. "Preparation and thermophysical properties of $\mathrm{CeO}_{2}$ doped $\mathrm{La}_{2} \mathrm{Zr}_{2} \mathrm{O}_{7}$ ceramic for thermal barrier coatings.” Journal of Alloys and Compounds 438 (2007): 217-221.

[63] M.P. Pechini. Method of preparing lead and alkaline earth titanates and niobates and coating method using the same to form a capacitor. U.S. Patent no. 3330697 (1963).

[64] F. Tietz, A. Schmidt, M. Zahid. "Investigation of the quasi-ternary system $\mathrm{LaMnO}_{3}$ $\mathrm{LaCoO}_{3}$-“ $\mathrm{LaCuO}_{3}$ ”-I: the series $\mathrm{La}\left(\mathrm{Mn}_{0.5} \mathrm{Co}_{0.5}\right)_{1-\mathrm{x}} \mathrm{Cu}_{\mathrm{x}} \mathrm{O}_{3-8 .}$." Journal of Solid State Chemistry 177 (2004): 745-751.

[65] A. Majid, J. Tunney, S. Argue, D. Wang, M. Post, J. Margeson. "Preparation of $\mathrm{SrFeO}_{\sim 2.85}$ perovskite using a citric acid assisted Pechini-type method.” Journal of Alloys and Compounds 398 (2005): 48-54.

[66] S.J. Lepe, J. Fernandez-Urban, L. Mestres, M.L. Martinez, Sarrion. "Synthesis and elevctrical properties of new rare-earth titanium perovskites for SOFC anode applications.” Journal of Power Sources 151 (2005): 74-78.

[67] N.S. Siefert, D. Shekhawat, M.W. Smith, D.J. Haynes, R.M. Bergen, E.H. Robey, R.S. Gemmen, D.A. Berry. "Operation of a solid oxide fuel cell on a reformed FAME mixture.” Biomass and Bioenergy 47 (2012): 362-371.

[68] U.S. Environmental Protection Agency. Regulatory Announcement EPA420-F-00-057. "Heavy-Duty Engine and Vehicle Standards and Highway Diesel Fuel Sulfur Control Requirements.” (2000) 
[69] Aerodyne Research, Inc. Research statement N101-033. (2010)

[70] M.W. Smith, D.A. Berry, D. Shekhawat, D.J. Haynes, J.J. Spivey. "Partial oxidation of liquid hydrocarbons in the presence of oxygen-conducting supports: Effect of catalyst layer deposition.” Fuel 89 (2010): 1193-1201. 